Florida International University FIU Digital Commons

5-1-1992

\title{
The relationship between spokesperson credibility and purchase intentions : a proposed theory and experimental evaluation
}

Oscar Winston DeShields

Florida International University

DOI: $10.25148 /$ etd.FI14062249

Follow this and additional works at: https://digitalcommons.fiu.edu/etd

Part of the Business Administration, Management, and Operations Commons

\section{Recommended Citation}

DeShields, Oscar Winston, "The relationship between spokesperson credibility and purchase intentions : a proposed theory and experimental evaluation" (1992). FIU Electronic Theses and Dissertations. 2779.

https://digitalcommons.fiu.edu/etd/2779 
ABSTRACT OF THE DISSERTATION

The Relationship Between Spokesperson Credibility and Purchase Intentions: A Proposed Theory and Experimental Evaluation

by

\author{
Oscar Winston DeShields, Jr.
}

Florida International University, 1992

Miami, Florida

Professor Frank J. Carmone, Jr., Major Professor

The purpose of this dissertation is to develop and evaluate an expanded spokesperson credibility model to address issues uncovered in Ohanian's (1991) study about linkages between spokespersons' credibility and consumers' purchase intentions. Based on Tajfel's social categorization theory (1981), 12 hypotheses were developed to test direct and indirect relationships between spokesperson's credibility and purchase intentions.

The sample for the study consisted of 1,162 respondents $82.9 \%$ students and $17.1 \%$ nonstudents; $48.2 \%$ males and $51.4 \%$ females; $31.3 \%$ Caucasian (American); $24.5 \%$ Cuban (American); $19.6 \%$ other Hispanics and $22.5 \%$ other ethnic groups. The data were collected by having respondents either view a video tape or listen to an audio tape in a classroom or shopping mall setting. The respondents were told that they would hear a spokesperson presenting a message. After listening to the message they would then be asked to complete a questionnaire.

The spokesperson credibility model was tested using covariance structure analysis as implemented in the LISREL software. A series of ANOVAs were used to test the impact of the moderating variables on purchase intentions.

The findings indicate that Ohanian's (1991) credibility constructs i.e., attractiveness, trustworthiness, and expertise are significantly related to purchase intentions. In addition, the following interactions were found to be statistically significant: 


\section{FLORIDA INTERNATIONAL UNIVERSITY \\ Miami, Florida}

The Relationship Between Spokesperson Credibility And

Purchase Intentions: A Proposed Theory And

Experimental Evaluation

A dissertation submitted in partial satisfaction of the requirements for the degree of Doctor of Philosophy in Business Administration (Marketing)

by

Oscar Winston DeShields, Jr. 
To Professors Carmone:

Greenberg:

Seaton:

Tsalikis:

Kelley:

This dissertation, having been approved in respect to form and mechanical execution, is referred to you for judgement upon its substantial merit.

Dean Harold E. Wyman

College of Business Administration

The dissertation of Oscar Winston DeShields, Jr. is approved.

Frank J. Carmone, Jr., Major Professor

Barnett A. Greenberg

Eugene J. Kelley

F. B. Seaton

John Tsalikis

Henry A. Laskey

Date of Examination:

May 1, 1992

Dean Richard Campbell

Division of Graduate studies

FIorida International University, 1992 
With love to my mother, who always supported and encouraged me 
A number of individuals contributed to this dissertation. All members of my committee were extremely helpful and dedicated throughout the research process. Dr. Frank J. Carmone, Jr. guided me through the research process with his insightful methodological comments. Dr. Barnett Greenberg encourage me by accelerating the timetable to produce this study. Dr. Henry A. Laskey provided the initial assistance and suggestions to produce the proposal that resulted in this study. Dr. Bruce Seaton's critical editorial comments and recommendations provided the bases to make major improvements in the manuscript. The genesis of the idea for this study began its formation in an earlier research paper which Dr. John Tsalikis and I published on spokesperson's accent. Dr. Eugene Kelly provided continual encouragement and clarification for the focus and contribution of the research. There were two individuals who were particularly helpful to me with covariance structure analysis as implemented in the LISREL software. Dr. Arturo Vasquez's critique of the spokesperson credibility model and the results of the LISREL analysis provided the bases to make significant modifications and improvements in the model and presentation. Dr. Werner Wothke, technical support expert for the scientific software, Inc. provided the guidance and assistance necessary to ensure that the LISREL program was correctly developed for the model that was use in the study. 
LIST OF TABLES

LIST OF FIGURES

CHAPTER

I INTRODUCTION

Communications Processing Model . . . . . . 2

II LITERATURE REVIEW . . . . . . . . . . . . . 6

Spokesperson . . . . . . . . . . . 6

Spokesperson Expertise . . . . . . . 8

Spokesperson Attractiveness . . . . . . 9

Spokesperson Trustworthiness . . . . . . 13

Spokesperson Accent . . . . . . . . . 14

Spokesperson Summary . . . . . . . . . 16

Communication Modality . . . . . . . . . . 17

Communication Modality Summary : $:$ : $:$ : 19
Decoding : . . . : 21

Approach . . . . . . . . . . . . 21

Theory . . . . . . . . . . . . . 24

Decoding Summary . . . . . . . . . 29

Receiver . . . . . . . . . . . . . 30

Involvement/Audience . . . . . . . . . 31

Bilingualism/Audience .. . . . . . . 34

Audience Summary . . . . . . . . . 35

Response . . . . . . . . . . . . . . 37

Literature Review Summary . . . . . . . 39

III FOCUS OF STUDY . . . . . . . . . . . 40

Statement of Problem ........... 40

Objectives of Study............. . . 41

Significance of study............ . 42

IV MODEL OF THE RELATIONSHIP BETWEEN SPOKESPERSON AND THE CONSUMER'S PURCHASE INTENTIONS AND THE RESEARCH

HYPOTHESES . . . . . . . . . . . . . . 44

Model .................... 44

Hypotheses. . . . . . . . . . . . . . 46

Summary . . . . . . . . . . . . 56 
Pre-Test for spokesperson's Attractiveness and Accent . . . . . . . . . . . . . . 57 Questionnaire . . . . . . . . . . . 61 Measurement of Terms . . . . . . . . . 62 Reliability of the Measures . . . . . . 64 Manipulation check ............. . 70 Research Design . . . . . . . . . . . 72 Data Collection Procedures . . . . . . . 74

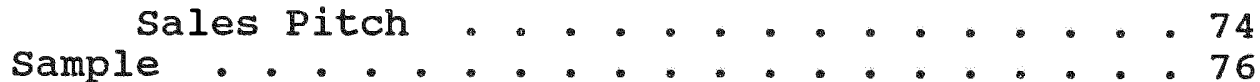
Analytical Techniques . . . . . . . . . 83 LISREL and Analysis of Variance for Summary ............... . . 90 Moderator Variables ........ . . 83

VI RESEARCH FINDINGS . . . . . . . . . . . . 92

The Spokesperson Credibility Model and Hypotheses . . . . . . . . . . . . . 92

Data Screening Procedure . . . . . . 93

Confirmatory Factor Analysis . . . . . 93

Model Fit and Parameter Estimates . . 96

Analysis of Variance for Moderator

Variables . . . . . . . . . . 99

Summary . . . . . . . . . . . . . 117

VI RESEARCH IMPLICATIONS, LIMITATIONS, AND EXTENSIONS 122

Managerial Implications . . . . . . . . 122

Spokesperson Credibility and Purchase

Intentions . . . . . . . . . . . 123

Using the SPCM to select the Spokesperson 124 Spokesperson credibility and the

Nature of the Audience . . . . . . . 125

Implications for the Domestic and

International Markets . . . . . . 126

Research Implications . . . . . . . . . 127

Tajfel's Decoding Theory . . . . . . 128

Expanded Spokesperson Credibility Model 129

Generalizability and validity of

the Research ............ 130

Limitations of Study . . . . . . . . . . .130

Research Extensions . . . . . . . . . 135

Summary . . . . . . . . . . . . 136

APPENDIX A--Questionnaire . . . . . . . . . . 138 APPENDIX B--Bibliography . . . . . . . . . . . . 144 


\section{LIST OF TABLES}

TABLES

PAGE

2-1. Advertising Effectiveness Model and Measures . . 38

5-1. Repeated Measure of Analysis of Variance for Levels of Attractiveness . . . . . . . . . . . 59

5-2. MANOVA Test Criteria and Exact $F$ statistics for the Hypothesis of No Attractiveness*Sex . . . . . . 60

5-3. 15-Item Semantic Differential Scale Adjectives . . 61

5-4. Factor Loading from Exploratory Factor Analysis . . 66

5-5. Reliability Measures for the study . . . . . . . 67

5-6. Cronbrach Alphas for Presenters . . . . . . . . . 68

5-7. Cronbrach Alphas for Accents . . . . . . . . 69

5-8. Analysis of Variance for High and Low Attractive Spokespersons . . . . . . . . . . . . . . 71

5-9. Research Sample--Sex . . . . . . . . . . . 77

5-10. Research Sample--Age .. . . . . . . . . . 77

5-11. Research Sample--Education . . . . . . . . . 78

5-12. Research Sample--Occupational Profile... . . . 78

5-13. Research Sample--Income Profile . . . . . . . . 79

5-14. Research Sample--Respondents Language . . . . . . 79

5-15. Research Sample--Respondents Ethnic Profile. . . 80

5-16. Respondents Native Language . . . . . . . . . . 80

5-17. Language Respondents Speak with Parents . . . . . 81

5-18. Birth Place of Respondents . . . . . . . . . . 81

5-19. Residence in the United States of America. . . . 82

5-20. Birth Place of Parents . . . . . . . . . . . 82

5-21. Respondent cell count Breakdown . . . . . . . . 83

5-22. Summary of Measures . . . . . . . . . . . 88

6-1. Indicators Variables in Spokesperson Credibility

Model . . . . . . . . . . . . . . . 94

6-2. Correlation Matrix of Spokesperson Credibility Model . . . . . . . . . . . . . . . .97

6-3. Summary statistics for Confirmatory Factor Analysis . . . . . . . . . . . . . . . 98

6-4. Analysis of Variance--Involvement/Attractiveness 105

6-5. Analysis of Variance for Involvement/Audio-only Presentation of the Spokesperson . . . . . . 105

6-6. Analysis of Variance--Involvement/Trustworthiness 107

6-7. Analysis of Variance--Involvement/Expertise . . . 108

6-8. Analysis of Variance--Accent/Attractiveness . . . 109

6-9. Analysis of Variance for Spokesperson's Accent and Audio-only Presentation . . . . . . . . . . 119

6-10. Analysis of Variance--Accent/Trustworthiness . . 110

6-11. Analysis of Variance--Accent/Expertise . . . . . 111

6-12. Analysis of Variance--Audience, Spokesperson's Accent and Attractiveness . . . . . . . . . . 114

6-13. Analysis of Variance--Audience, Spokesperson's Accent and Audio-only Presentation . . . . . 115 
6-14. Analysis of Variance--Audience, Spokesperson's Accent and Trustworthiness . . . . . . . . 116

6-15. Analysis of Variance--Audience, Spokesperson's Accent and Expertise ............. 117

7-1. Modification Indices \& Estimated Change--LISREL Model .................... 132

7-2. Exploratory Factory Analysis for variables in the Spokesperson Credibility Model . . . . . . 135 


\section{IIST OF EIGURES}

FIGURE

PAGE

1-1. The Communications Model . . . . . . . . . 2

2-1. Dimensions of Spokesperson Credibility . . . . . 8

2-2. Media--Visual and Verbal Loop Possibilities . . . 20

2-3. Decoding Approach and Theory . . . . . . . . . . 21

2-4. Insecure Intergroup Social comparisons . . . . . . 28

2-5. Receiver/Audience Conditions . . . . . . . . . . 31

2-6. Response Options . . . . . . . . . . . . . 37

4-1. Spokesperson, Moderator, Purchase Intentions Model - 44 4-2. Topology of Specification Variables . . . . . . 445

5-1. Research Design . . . . . . . . . . . . 73

5-2. LISREL Diagram: Spokesperson Credibility Model . 87

6-1. LISREL Estimates for Research Hypotheses... . . 101

6-2. LISREL Estimates for Attractiveness Hypothesis . . 102

6-3. LISREL Estimates for Trustworthiness Hypothesis . 103

6-4. LISREL Estimates for Expertise Hypothesis . . . 104 


\section{CHAPTER I: INTRODUCTION}

In 1900 , the United States spent 2.9 percent of its total gross national product, representing $\$ 542$ million, on advertising expenditures (Patti and Frazer, 1988). By 1986, advertising expenditures rose to $\$ 85$ billion, representing 2.3 percent of the total gross national product (Bovee and Arens, 1989). Media expenditures accounted for most of advertising dollars. The ranking of 1986 advertising media expenditures in descending order are as follows: newspapers, television, direct mail, radio, magazines, and outdoor.

Advertising is a form of communication and uses the communication process. There is presently no prevailing theory of advertising or advertising outcomes. The basic model of the communication process presented in most fundamental marketing and advertising textbooks is, therefore, often used to explain how advertising influences or persuades an audience.

Figure 1-1 depicts the basic communications model. The communication process begins with a sender transmitting a message to an audience. The sender first encodes the message. This message is transmitted via some medium to the audience. The received message is then decoded by members of the audience receiving the message. Receivers respond to the message by giving feedback or measurable responses to the sender. 
FIGURE 1-1

ELEMENTS IN THE COMMUNICATION PROCESS

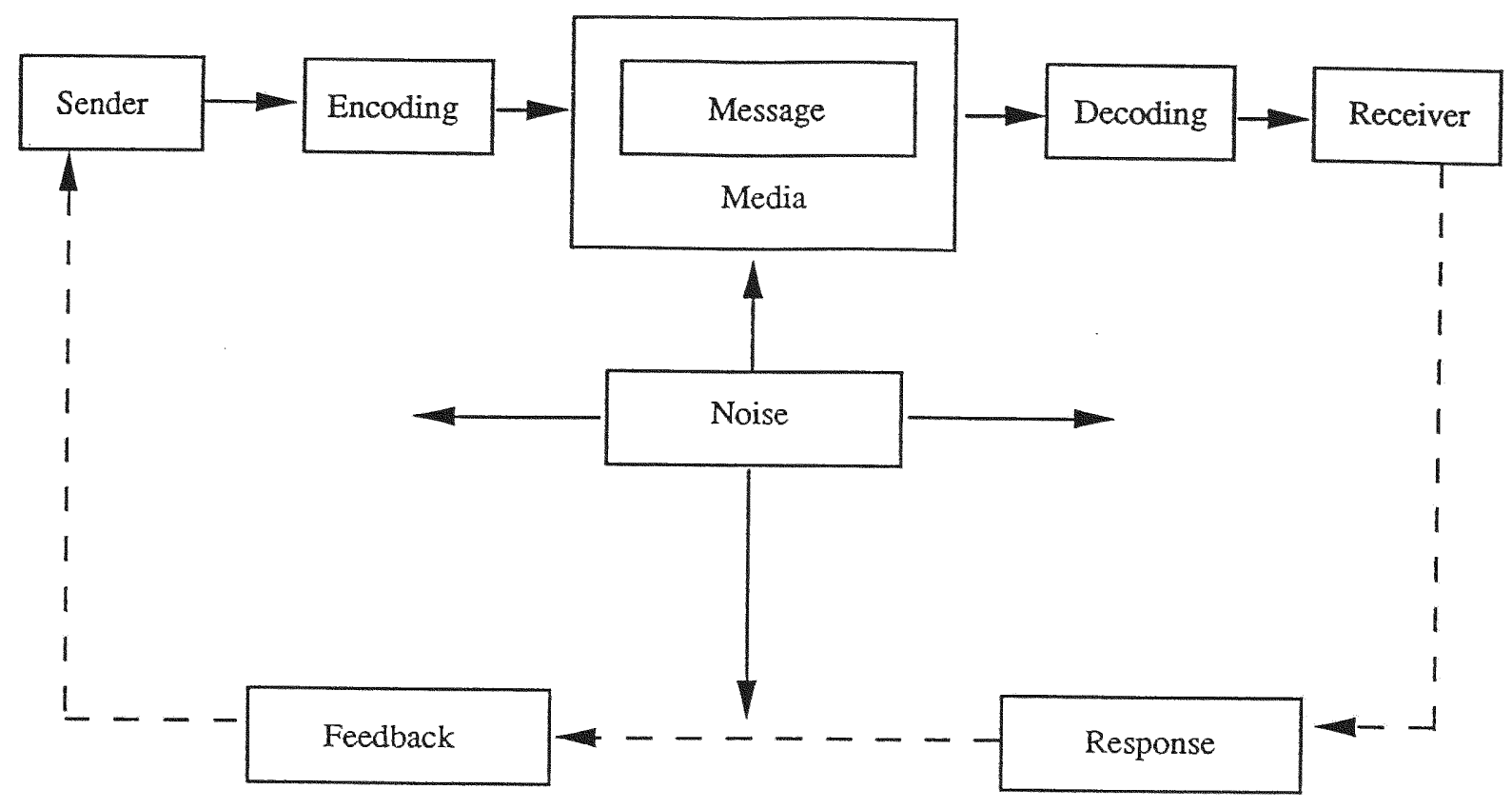

C. Shannon and $W$. Weaver, The Mathematical Theory of Communications (Urbana: University of Illinois Press, 1949), in Severin, Werner, J., and James W. Tankard, Jr. Communication Theories: Origins, Methods, Uses (New York: Hasting House, 1979) p. 31. 
Unanticipated static or distortion during the communication process (i.e., noise) may cause the receiver not to receive the message as it is intended by the sender.

Kotler and Armstrong (1989) have noted that the receiver's perception of the sender influences message effectiveness. A presenter's credibility factors or positive traits--for example, attractiveness, trustworthiness, expertise, and accent--influence the receiver's approval of the message. The effect of spokesperson credibility factors is dependent upon the attitudes and behaviors of the target audience (Aaker and Myers, 1987). Knowing the factors that influence audience perception of spokesperson's credibility, and understanding the relationship between spokesperson characteristics and perceived credibility can enable a sponsor to select the most effective spokesperson for a particular target audience (Hovland, Janis, and Kelly, 1953; Choo, 1964; Hamon and Coney, 1982; Ohanian, 1991). Messages that are transmitted by highly credible spokespersons would be more persuasive. Consequently, the factors which determine spokesperson credibility are of great interest to practitioners and researchers alike.

Aaker and Meyers (1987) distinguished two general approaches to understanding how the receiver evaluates information from the spokesperson: one, cognitive or thinking response, is a model in which the attributes of an item are evaluated, weighted, and then combined to give a general attitude toward the item. The other, category-based 
evaluations, divides the world into meaningful categories into which the receiver can place items or characteristics of items retrieved from memory. The consumer is thought to process information in a logical, rational manner which can potentially change beliefs, attitudes, and behavior. Alternately the information can create feelings, through identification with a category, that can ultimately influence attitudes and behavior. Pavelchak (1989) reported that individuals can be expected to use the rational or piecemeal approach only if they cannot retrieve information from their memory to categorize the incoming information. The categorybased approach is more efficient because it is based upon stereotyping. For example, if an individual thinks everyone with an accent is stupid, and the person to be evaluated has an accent, then it is not necessary to analyze each of the person's other characteristics to conclude that the person is stupid.

Recognition of standard categories of patterns has been demonstrated to be useful in a number of areas. Chase and Simon (1973) reported that the chess expert's intuition for the game came from the rapid recognition of standard patterns. Larkin, McDermott, Simon, and Simon's (1980) study showed that expertise in physics was attributed to the ability to categorize a problem based on the underlying axiom and then apply the solution connected with that category of problems. The focus of this dissertation is on examining how an audience decodes messages from various spokespersons. This 
study is intended to explain the relationships among four elements of the communication model: 1) the sender, 2) the decoding process, 3) the receiver, and 4) the receiver's response, while holding constant the method of encoding and the nature of the message, the media, and noise elements.

Chapter II reviews the relevant literature for this research. The literature is organized around the communication model in the following manner: spokesperson Credibility Factors, Decoding Approaches, Communication Modality, Receiver or Audience Conditions, and Response Indicators. Chapter III presents the focus of the study. Based on a theory of decoding, a causal model is developed in Chapter IV. The model shows the direct and indirect relationships among the dimensions of spokesperson credibility and the consumer's response (e.g., purchase intentions). The twelve main hypotheses are developed in this chapter. Chapter $V$ presents the research methodology that was used to conduct the study: the design, sample population, data collection procedures and instruments, methodological assumptions and analytical techniques. Chapter VI discusses the research findings. Chapter VII focuses on the research implications, limitations, and extension of the study. Finally, Appendices $A$ and $B$ contain the research instrument and the reference list. 


\section{CHAPTER II: LITERATURE REVIEW}

The literature review is organized in five parts, corresponding to key parts of the communication processing model: 1) the source person or spokesperson, 2) communications modality--the vehicle used to send the message, 3) decoding-the way the receiver evaluates the information, 4) the receiver or audience, and 5) the receiver's response to the advertisement--the intentions to purchase. The first part of the literature review focuses on the sender or source of the message. Next is included a brief overview of the literature on the impact of the media used to transfer messages to receivers. This emphasizes the appropriateness of the specific vehicles to be used in the study. Following the overview, an assessment of the primary decoding approaches used by receivers is presented, while the receiver section identifies aspects of the audience's composition to their accepting a message. Finally, ways in which an audience may respond to information are discussed.

\section{I. spokesperson}

Communication researchers had focused their efforts on identifying those attributes of spokespersons that account for the effectiveness of persuasive communication (Hovland, Janis, and Kelly, 1953). Dimensions of spokesperson credibility that have been investigated include: (1) spokesperson expertise (Mills and Harvey, 1972; Horai, Naccari, and Fatoullah, 1974; Swartz, 1984); (2) spokesperson attractiveness--similarity, familiarity, and likability (Brock, 1965; Albert and Anderson, 
1973; Swartz, 1984; Bone et al., 1986; Sigall and Aronson, 1969; Baker and Churchill, 1977; Doin and stein, 1978; Chaiken, 1979; Joseph, 1982; and Patzer, 1983); spokesperson trustworthiness (Miller and Baseheart, 1969; Friedman and Friedman, 1976; Friedmand, Santeramo and Traina, 1979; Mcginnies and Ward, 1980); and, (4) spokesperson accent (Tsalikis, DeShields, and LaTour, 1991).

Assessing the impact of spokesperson credibility requires that attitudes and behaviors of a target audience are explicitly taken into account (Aaker and Myers, 1987). Focusing on the source portion of the communication processing model, FIGURE $2-1$ depicts the various dimensions of spokesperson credibility most frequently cited in the literature.

The model shows that spokesperson credibility is a multidimensional construct with both cognitive and affective dimensions. The cognitive dimension focuses on the receiver's evaluation of a spokesperson's competence or expertise, while the affective dimension accounts for the receiver's evaluation of the trustworthiness and attractiveness of the spokesperson. A receiver may find a source attractive in terms of intellectual skills, personality properties, lifestyle characteristics, physical attributes, opinions, background, etc. Spokesperson similarity is significant to establishing credibility. Rather than simply envying, liking, or admiring a spokesperson, the audience could identify with him or her. 


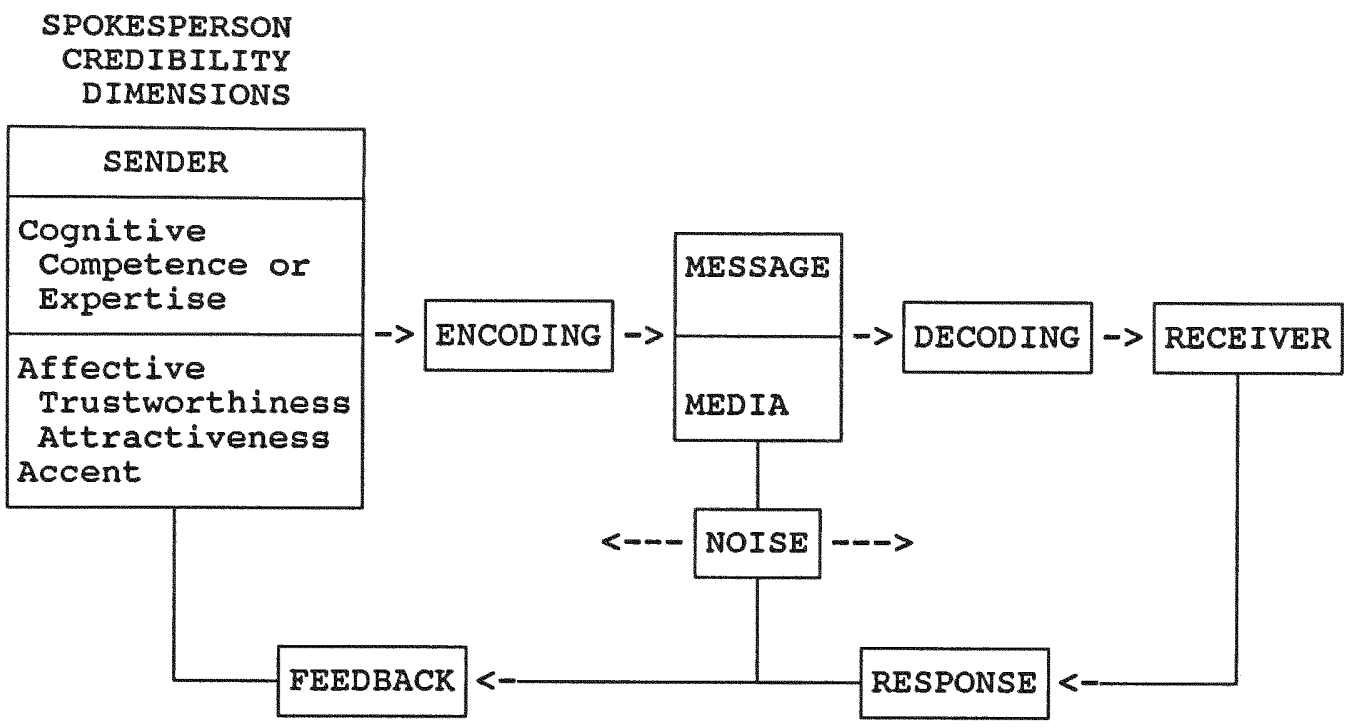

Similarity can enhance empathy and thus achieve identity (Aaker and Meyers, 1987). The role of accented speech in spokesperson credibility (Figure 2-1) must be considered in a multicultural context (Tsalikis, DeShields, and LaTour, 1991). Since there are more bilingual than monolingual persons worldwide (Marcos and Urcuyo, 1979), accented speech influences the cognitive and affective dimensions of credibility.

\section{Spokesperson Expertise}

A perceived, as opposed to an absolute phenomenon, expertise refers to the knowledge, experience, or skills demonstrated by a spokesperson for a specific issue (Shimp, 1990). A spokesperson who is perceived as having expertise 
will be more persuasive than a spokesperson who is perceived as lacking in expertise. Ohanian (1990) reported a variety of studies that have indicated the positive influence of expertise on attitude change. Shimp (1990) noted ways in which marketing communicators enhance source expertise. These include extensive training, recruitment of highly experienced persons, convincing ads with realistic settings, props, paraphernalia, and believable spokespersons.

An expert is likely to be the most appropriate spokesperson of technical products or for reassurance that the product is safe (Aaker and Myers, 1987). In these capacities, an expert can reduce concerns about side effects, knowing how a product operates or is used. The expert can take on a variety of images such as medical doctor, lawyer, engineer, celebrity, or a satisfied customer.

\section{Spokesperson Attractiveness}

Spokesperson attractiveness, a general concept, encompasses three features: similarity, familiarity, and liking (Swartz, 1984). Persuasion through an identification process is based on the receiver finding the source attractive in terms of intellectual skills, personality properties, lifestyle characteristics, etc. Spokesperson attractiveness is a multidimensional construct that is reflective of the saying that Beauty is in the eye of the beholder. That is, the receiver could be attracted to the spokesperson for a variety of subjective reasons. 
The particular attributes studied by judges (e.g., a person's hair color, or the shape of the nose) are typically not important (Joseph 1982). However, Joseph reported that most of the research on physical attractiveness has concentrated on facial attractiveness, although facial cues may not be the only determinants of an individual's physical attractiveness. However, perception research shows that they may be the most significant factors of an individual's physical appearance.

Joseph's (1982) review of the experimental findings from advertising and related disciplines on the impact of physically attractive spokespersons and models on opinion change, product evaluation, source perception, and recall shows that attractive--as compared to unattractive-spokespersons are consistently liked more, are viewed in more favorable terms, and have a positive effect on the products with which they are associated. A more recent literature review by Chaiken (1986) suggests that by controlling for all the other factors that may affect a respondent's evaluation of an item, a message presented by a physically attractive spokesperson will tend to be more persuasive than a similar message presented by a less physically attractive spokesperson.

Snyder and Rothbart (1971) reported that source attractiveness is related positively to agreement, although the impact seems to be less consistent when the spokesperson is a female. Furthermore, they noted that there were no 
differences between attractive and unattractive spokespersons on perceived honesty, competence, dominance, personal effectiveness and personal success. Miller's (1970) assertion that physically attractive sources are viewed as having a strong internal locus of control suggests that these individuals are not easily affected or manipulated by others and that they are independent thinkers with personal convictions. These attributes suggest greater source credibility.

Although liking a spokesperson does not always produce instantaneous changes in attitude, its significance as an antecedent of social impact has been established in several investigations (Blass, Alperstein, and Block, 1974). A person with a positive attitude toward a spokesperson will probably evaluate that spokesperson's message in positive terms losgood and Tannenbanum, 1955). Kelman (1961) theorized, from a motivational perspective, that spokesperson physical attractiveness is significant because it may satisfy identification needs for individuals.

Baker and Churchill (1977) noted that the generality of the physical attractiveness-persuasiveness influence may be restricted by the type of product or topic, the sex of the receiver, and the sex of the spokesperson. Kamins (1990) used social adaptation theory to explain that the effectiveness of a physically attractive celebrity is moderated by the relationship that the product has with the celebrity. For example, if the product can be viewed as contributing to or 
compatible with the celebrity's image, then the celebrity as spokesperson can significantly enhance the credibility of the advertisement for that particular product. Landy and sigall (1974) concluded that a model's physical attractiveness would not be important if the product being promoted already has a strong brand image or clearly observable benefits. However, if the product does not contain these advantages, various irrelevant cues, including a model's physical attractiveness, may prominently affect the customer's response to the product and the advertisement. Joseph (1977) reported that when a female spokesperson is an expert, her physical attractiveness has little effect on subjects" preferences; however, when she is not an expert, subjects agree more with a highly attractive spokesperson than with a medium or low attractive spokesperson. In other words, when objective or task-related characteristics are weak, subjects will resort to irrelevant cues such as physical attractiveness to form opinions.

Umberson and Hughes (1987) used status characteristics theory (SCT) to explain the effects of physical attractiveness on psychological well-being and achievement. Berger, Fisk, Norman, and Zelditch (1977) had defined a status characteristic as:

"any characteristic that has differentially evaluated states that are associated directly or indirectly with expectation states" (p. 35).

A status characteristic is a distinguishing feature that can be used to classify the individual; for example, a positive or negative category such as attractive or unattractive. 
Consequently, SCT and Berger and colleagues' (1977) definition and use of a status characteristic fits Aaker and Meyers' (1987) criteria of a "category" that individuals use to differentiate and evaluate others.

Umberson and Hughes' (1987) observation that status characteristics may be generalized across persons (race, sex) or particularized in selected situations (specific skills, knowledge, ability) helps explain inequality in social interaction brought about by categorizing.

Webster and Driskell's (1983) review indicates that attractiveness meets the criteria for a diffused status characteristic in the sense that a generalized state of attractiveness may be associated with the ability to perform certain tasks better.

According to this line of thinking, a group of people consisting of "white attractive males" in the U.S.A, may be connected with greater perceived ability and skills (Webster and Driskell, 1983; Eagly and Wood, 1985; Cohen and Roper, 1972). The status characteristic of "white attractive male" becomes a criterion to categorize individuals according to Aaker and Meyers' (1987) description of the evaluation assumptions used by individuals in category-based models.

\section{Spokesperson Trustworthiness}

Trustworthiness--the honesty, integrity, and believability of a spokesperson--indicates how objective and honest the spokesperson appears to be (Kotler and Armstrong, 1989; Shimp, 1990). The degree of honesty or trustworthiness 
of a spokesperson is primarily contingent upon the respondent's perception of the spokesperson's intent (Shimp, 1990). Consequently, a spokesperson perceived as having a hidden agenda that promotes self-interest will be less persuasive than one perceived as not acting out of selfinterest. Hunt, Domzal, and Kernan (1982) reported that an individual speaking favorably about a product without being aware of a hidden camera is perceived as more trustworthy and credible than a spokesperson who is aware of being on camera.

Evidence that presenters' trustworthiness helps to alter recipients' perspective includes Miller and Baseheart's (1969) report that trustworthy spokespersons were more persuasive than spokespersons lacking in trust. McGinnies and Ward (1980) noted that presenters who were rated high on trustworthiness were more persuasive than presenters who were rated lower on the trustworthiness dimension.

\section{Spokesperson's Accent}

Tsalikis, Deshields, and LaTour (1991) noted that the role of accent in. spokesperson's credibility has been overlooked in the marketing literature, although this area has received much attention in the social psychology and linguistics literature. A number of researchers have posited that speech style, including accent, appears to have a powerful impact on the ratings of respondents over a broad range of characteristics attributed to the presenter (Lambert, 1967; Labov, 1972a; Labov, 1973; Giles, Baker, and Fielding, 1975; Giles and Sassoon, 1983; Bradac and Wisegarver, 1984). 
Some investigations in the U.S. have focused on comparing reactions to: (a) various regional dialects of American English (Shuy, 1968; Tucker and Lambert, 1969,), and (b) to other languages, such as Spanish (Williams, Hewett, Miller, Naremore and Whitehead, 1972; Carranza and Ryan, 1975; Flores and Hopper, 1975; Berk-Seligson, 1984).

Edwards (1982), reported that a variety of investigations in English-speaking countries (e.g., the United States, Canada, Britain, and Australia), found that presenters with a standard accent or dialect were perceived to exhibit more traits of (a) competence as perceived through intelligence, confidence, ambition, and industriousness, and status/prestige, as perceived through professionalism. However, presenters with nonstandard accent were perceived as having more traits of (a) personal integrity: sincerity, reliability, and generosity, and (b) social attractiveness: friendliness and warmth (Lambert, 1967, Giles and Powesland, 1975, Powesland and Giles, 1975). Similar results were reported by Giles $(1970,1971)$ in his comparison of British Received Pronunciation--a non-regional/standard English -with two regional dialects.

Berechree and Ball (1979) noted in an Australian investigation that greater competence and social attractiveness ratings were displayed for the cultivated Australian as opposed to the two other dialect varieties-Broad and General. Also, Carranza and Ryan (1975), reported comparable results in an investigation of responses to Spanish 
and English presenters, where English was viewed more favorably than spanish on the dimensions of integrity, attractiveness, and status. Additional support for these findings was noted in an investigation of speech patterns in a Canadian setting by Edwards and Jacobsen (1987), and in indigenous versus foreign-accented presenters (Ryan, Carranza and Moffie, 1977; Ryan and Giles, 1982; Callan, Gallois and Forbes, 1983; Compos and Astorga, 1986).

Garcia (1984) explained how individuals categorize persons by speech characteristics (e.g., accent, speech style). Using Tajfel's (1971) theory of social categorization and conceptualizations of intergroup relations and psychological distinctiveness (Tajfel, 1974, 1978), Garcia (1984) obtained evidence that the speech characteristics of a person play a fundamental role in assessing, among other things, race, age, social class, profession, and way of dressing.

\section{Spokesperson summary}

The sender initiates the communication process. A review of the marketing, psychology, sociology, social-psychology, and linguistics literature indicates that two primary dimensions that influence the receiver's evaluation of the presenter: cognitive (competence or expertise) and affective (trustworthiness and attractiveness). Also, the accent dimension, which has both cognitive and affective components, was identified. These attributes (i.e, attractiveness, trustworthiness, expertise, and accent) were cited in the 
marketing literature as indicators of spokesperson credibility.

II. Communication Modality

There is inconclusive evidence about the role of types of communications modes. According to some studies, not only do live or videotaped messages bring about greater opinion change than oral or audiotaped messages, but they also effect greater change than written messages (Frandsen, 1963; Haugh 1952). Other investigations show, however, that persuasiveness is not contingent on the type of modality and that greater opinion change is not dependent on written communication (McGinnies, 1965; Tannenbaum and Kerrick, 1954; Worchel, Andreoli and Eason, 1975). On the other hand, research on comprehension shows that written presentation typically results in greater comprehension than does audiotaped or videotaped presentation (Wilson, 1974; Jacoby, Hoyer, and Zimmer, 1983). Westover (1958) noted that advantage of written messages may only be exhibited with relatively complex material.

The greater ability of the written modality to transmit information appears to be paradoxical in view of the bulk of persuasion findings that, for example, good reception of a message generally facilitates opinion change (McGuire, 1968, 1972). The relationship is typically viewed as the result of comprehension influencing the quantity of information that the recipient can obtain in support of the conclusion of the message. Or it may be a function of the negative effect 
provoked by the recipient's efforts to understand material that is not easily comprehended (Eagly, 1974).

The tendency for an understanding of message content to enhance persuasion implies that the lack of consistency across previous modality investigations may have been caused by inadequate controls for message understanding. Chaiken and Eagly (1976) investigated the impact of easy or difficult-tounderstand persuasive messages via written, audiotaped, or videotaped modality on persuasion and understanding. Their results indicated that the relationship between communications mode and persuasion and comprehension may be influenced by the degree of message difficulty. When messages are difficult, the written mode had a more positive effect on persuasion and comprehension than videotaped and audiotaped messages. When messages were easy, the three modes had an equal effect on comprehension. However, persuasion was affected most by videotaped messages, least by written message, and moderately by audiotaped messages.

The visual and verbal impact of advertising on the consumer has been studied from a variety of perspectives and in various media. In an effort to understand how television's verbal and visual message components influence the consumer, the notion of the iconic element (i.e., picture or gestalt aspects of picture) and noniconic element (i.e., verbal or emotional impression) has been used. Although both verbal and visual components have been hypothesized to be required to create meaning from an advertising message, there is some 
evidence that meaning may be created without the verbal component (Liu, 1986).

Childers and Houston (1984) reported on conditions for a picture-superiority effect on consumer memory. Rossiter and Percy (1980) proposed that the visual part of the advertisement can be as effective as the verbal part in developing beneficial product attitudes and persuading the buyer to acquire an item. The authors' theory predicts that visual content in advertising probably initiates a visual imagery loop, while verbal content in advertising probably initiates a verbal belief loop (Figure 2-2).

\section{Communication Módality summary}

In summary, the communication modality literature suggests that television media is an excellent medium for promoting comprehension and persuasion via non-complex messages. Although it is hypothesized that visual and verbal information is processed differently, understanding is obtained through the conversion of the information into the so-called noniconic elements. The emotional and verbal contents of these elements provide the basis for generating meaningful information through an affective impression as well as through an analytical and logical structure (Lui, 1986). Since credibility dimensions include both visual and verbal factors, the highest level of persuasion is expected to occur through a combination of those factors (Rossiter and Percy, 1980). As a result, the media is expected to facilitate the ability of the spokesperson to portray the 
verbal and nonverbal features inherent in the noniconic elements of the message.

FIGURE 2-2

MEDIA--VISUAL AND VERBAL LOOP POSSIBILITIES*

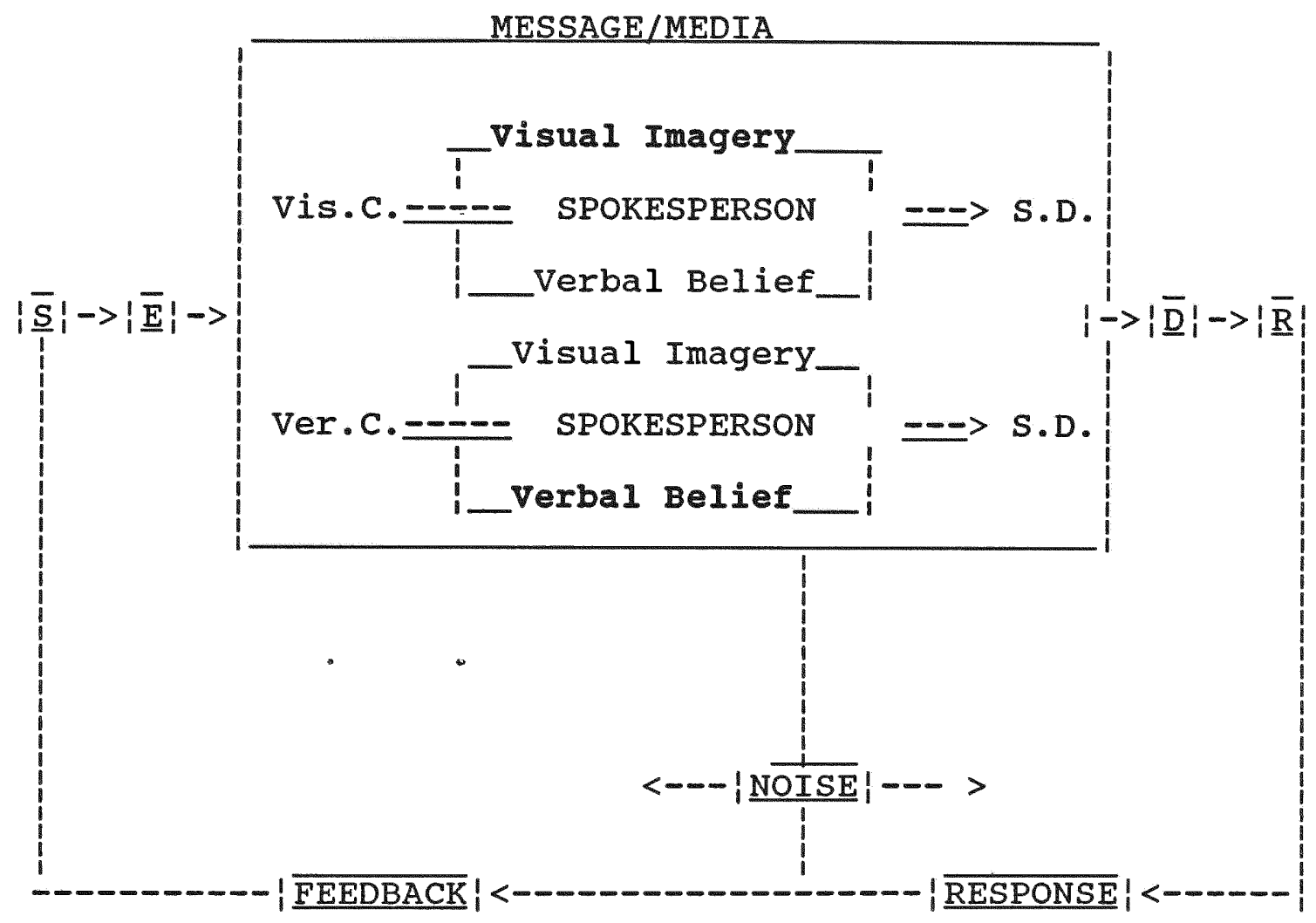

WHERE:

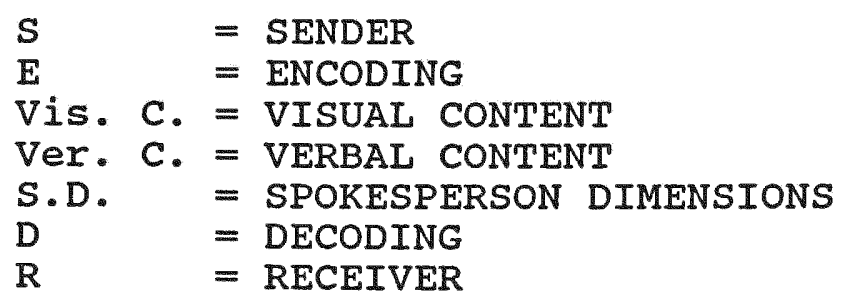

* The bold print emphasizes that the visual content in advertising is more likely to stimulate the visual imagery loop, whereas the verbal content in advertising is more likely to stimulate the verbal belief loop. 


\section{Decoding}

This section discusses two ways in which the receiver evaluates the message from the sender and the media (FIGURE 2-3).

FIGURE 2-3

DECODING APPROACH AND THEORY

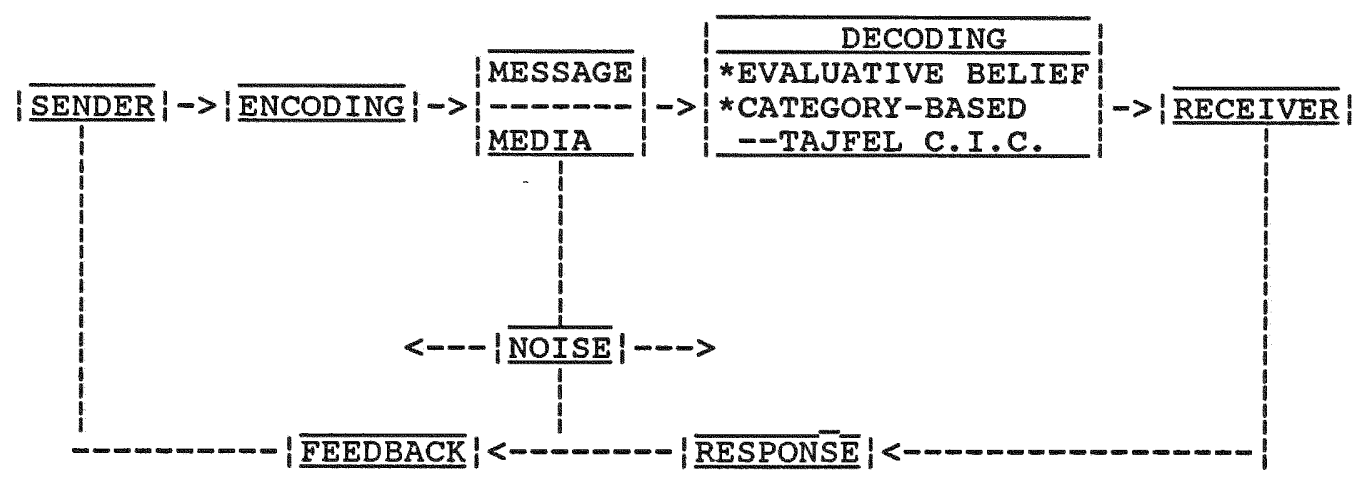

1. Approach

Two of the primary approaches that have been used to conceptualize how an individual judges other people are the evaluative belief model and the category-based evaluation model (Pavelchak, 1989). The evaluative belief model states that individuals piece together their assessments of other people based on their likability of the person's attributes (Anderson, 1974; Fishbein and Ajen, 1975). Category-based evaluations focus on the role of a person's memory in impression formation. Consequently, in social categorization, individuals frequently categorize social objects in order to 
make the world more comprehensible (Ashmore and Del Boca, 1981; Tajfel 1981; Sujan, 1985).

Fiske and Pavelchak (1986) generated a two-factor model to depict Ash's (1946) two decoding processes: the evaluative belief model and category-based approaches. Pavelchak (1989) defines categorization as:
"the identification of an object as a member of a class that results in the activation of the associated schematic knowledge" (p. 354).

Perceivers have schema connected to category members that pertain to a stimulus person when categorization is successful. Schema are speculated to be interconnected sets of nodes in memory and to function according to the principle of dispersing activation (Anderson, 1983; Wickelgren, 1981). The retrieval of a complete schema from memory is expedited by the transmission of activation from one node to another. Schema are perceived as hierarchical structures with general nodes at the upper level and more specific nodes at lower levels. The upper and lower level nodes represent category labels and category attributes, respectively. The nodes connected with both category labels and attributes have affective tags associated with them that show their relative likability. Pavelchak (1989) notes that social characteristics are more quickly used as labels than personal characteristics not only because they are more informative, but they are also easier to remember and to visualize. The results of Pavelchak's (1989) investigation indicated that the social categorization decoding approach is more 
appropriate for individuals who have pre-categorized people, while the piecemeal decoding approach is more appropriate for individuals who have not pre-categorized people. Based on their socialization, culture, values, and so on, individuals pre-categorize others along such dimensions as speech style, accent, race, and physical attractiveness. These attributes appear to have consequential impact on the ratings assigned presenters (Foon, 1986; Bernstein, 1962; Sigall and Aronson, 1969; Doin and Stein, 1978; Chaiken, 1979; and Patzer, 1983). Although individuals may use the above approaches to decode or evaluate others, the importance of a particular person's attributes for the piecemeal approach or the criteria used to categorize the person is based on the evaluator's perception of the world, which, in turn, is based on background, culture, and experiences. As a result, a variety of audience perceptions or world views can influence interpretation of the message from the spokesperson (Aaker and Myers, 1987). A person's needs, values, and social situation can determine how he or she interprets a particular spokesperson factor; the Gestalt emphasis on stimulus factors recognizes that perception is the outcome of the association of an active perceiver with a stimulus environment--that past episode sensitizes the person to react to various aspects of the stimuli and in different ways. Consequently, the audience characteristics as well as spokesperson factors need to be appraised. 
The social categorization decoding approach will be used for this investigation for two reasons: (1) the literature clearly shows that individuals do pre-categorize others according to such features as attractiveness, accent, and ethnicity; (2) the category-based decoding approach contains both cognitive and affective responses used by marketing researchers in their attempts to understand how the receiver evaluates the spokesperson.

\section{Theory}

The decoding theory to be used for this investigation is based on Tajfel's (1974, 1981, 1982) work in the social psychology of intergroup relations. Social psychology is concerned with the relationship between human psychological functioning and the social processes and events which shape this functioning. In this two-way relationship, (1) human psychological functioning impacts social processes and (2) social processes and events impact the human psychological functioning. Processes that lead to group identification build up awareness of membership which carries along with it some evaluative and emotional contents. The end result of this processing is manifested in stereotyping and categorizing. The categorization process minimizes withingroup differences and exaggerates between-group differences (Doise et al., 1978; Taylor et al., 1978). Members of a group tend to hold more similar beliefs than individuals who are not part of a group; the pattern applies to future behavior of the group (Wilder, 1978a). 
Similarity of beliefs may be attributed to social comparison, a process through which individuals develop selfimage. Festinger (1954) argued that by inter-individual comparison, a person tries to achieve a satisfactory selfconcept or self-image. However, Tajfel (1981) contended that inter-individual emphasis ignores the consequences of multiple group membership for self-concept and self-image formation.

Recognizing this shortcoming of Festinger's theory of social comparison, Tajfel used four related concepts to develop a theory that can explain the impact of the individual's 'social' setting on self-image: social categorization, social identity, social comparison, and psychological distinctiveness.

The process of categorization, as used by individuals to systematize and simplify their environment, presents certain theoretical continuities between the role played by categorizing in perceptual activities and its role in the ordering of one's social environment. Social categorization could be understood as ordering the social environment in terms of social categories. Categorization thus brings together social objects or events in groups--objects and events viewed similarly by persons who compose the groups.

similarity in members' actions, intention, attitudes, and systems of beliefs promotes social identity. Social identity is that part of a person's self-concept which is obtained from the person's knowledge of membership of social groups coupled with the emotional relevance connected to that membership. 
Social categorization must be viewed as a system of orientation which builds and specifies the person's position in society. By seeing themselves in socially-defined terms, people identify psychological and social realities of existence. To validate these realities, individuals will want to become members of a group that makes a positive contribution to their social identity. However, they also will leave a group that does not make a positive contribution to their social identity. Or, if they cannot leave, they will attempt to either change the negative interpretation of the group or take actions to change the group's image.

This view relates social categorization to social identity. The characteristics of one's group achieve most of their importance in relation to perceived differences from other groups and the value implied by these differences. Also, social identity based upon membership in particular social groups coupled with some emotional content and valued membership can be expressed through distinguishing one's own social group categories from other people's. Thus, a social group will be able to maintain its contribution to those features of a person's social identity which are positively valued by the person if that group is able to keep valued characteristics distinct from those of other groups.

The need for differentiation generates the sequence for social categorization, social identity, and social comparison (C.I.C.). The C.I.C theory assumes there is a preference for favoring in-group attributes and behavior which is activated 
by the need to maintain or acquire a positive group distinctiveness--a distinctiveness which in turn serves to protect, enhance, preserve, or achieve a positive social identity (Tajfel, 1974, 1981; Turner, 1975; Tajfel and Turner, 1979). This psychological distinctiveness enables hypotheses to be generated from the C.I.C. theory. Within this context, social identity is understood as an intervening causal mechanism in situations of social change and as the impact of these changes on subsequent intergroup behaviors and attitudes (Tajfel, 1972). Three conditions appear critical to initiating social change: a marginal or ill-defined group social situation, group superiority threatened by impending social change or value conflict, and group members' awareness of their inferior status and their desire to remedy their plight (Tajfel, 1981).

The matrix (FIGURE 2-4) illustrates the two-by-two classification of cases and predictions arising from individuals being in the various groups.

Insecure social comparisons arising within a group which is consensually defined as higher status (Box A and B) can result when (1) group superiority is challenged and (2) group superiority is derived through unfair or illegitimate means (Tajfel, 1981).

Box $A$ is not likely to have many instances as long as the threat does not become overwhelming. On the other hand, in Box B, when group superiority is threatened, increased 
security directed at keeping the superior group in its place can be predicted.

\section{FIGURE 2-4}

Insecure intergroup social comparisons

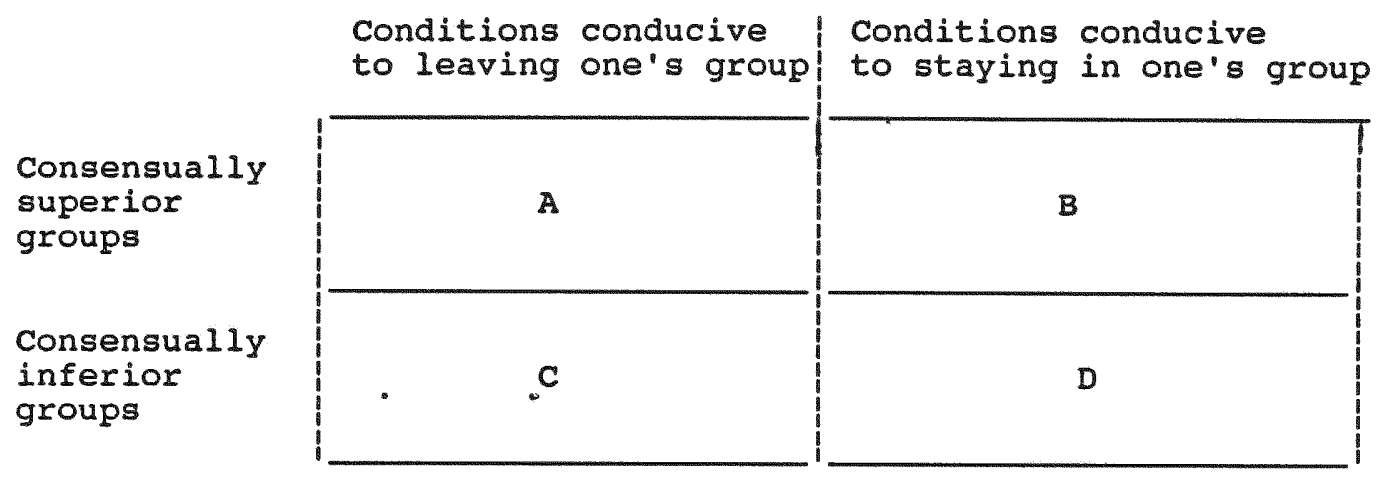

Mechanisms for maintaining superiority include the creation and use of new conditions for maintaining and increasing psychological distinctiveness, social and psychological isolation, and the creation of distinctive symbols. Where superiority is unfairly or illegitimately derived, Box A defines a situation in which conflict of values is high enough to ruin positive contributions the group renders to social identity (e.g., apartheid society for whites, upper or middle class revolutionaries, "renegades" of all kinds). Thus, conditions would be conducive to leaving one's own group. In Box B, for unfairly derived superiority, value conflicts exist, but in-group affiliation is sufficiently adequate to influence attitudes and behaviors. Here, conflicting values can only be settled through finding new justifications for the maintenance of status quo (e.g., the "white man's burden", the 
inherent superiority due to unbridged innate differences, the "saving of souls").

Conditions conducive to leaving one's own group (Box C) are reflected in situations of social mobility, in which flexibility permits transfer from one group to another with inconsequential sanctions and conflict of values. Where boundaries between groups are not clearly established, a strategy of individual assimilation, including illegitimate assimilation, is often adopted (Giles and Johnson, 1981; Tajfel, 1982). Examples of illegitimate assimilation include concealing one's background or origin and changing one's name. Conditions conducive to staying in one's own group are reflected in situations such as the caste system or any other social differentiation system which, for whatever reasons, forbids or impedes transfer. The major psychological conditions include a strong conflict of values inherent in abandoning the group, fear of strong social sanctions for moving, or a mixture of both.

\section{Decoding summary}

A review of the decoding literature indicated that there are two primary approaches to understanding how the receiver evaluates the spokesperson: evaluative belief model and the category-based model. The category-based decoding model appeared to be more appropriate for studying how receivers evaluate the credibility of the spokesperson. Thus, Tajfel's C.I.C. theory--a category-based model--was used to explain how the receiver decodes or evaluates the spokesperson. 
Accordingly, the receiver evaluates credibility by first categorizing the spokesperson along the dimensions of attractiveness, trustworthiness, and expertise. These dimensions are modified by the spokesperson's accent, involvement with the product, and the respondent's ethnic background. Secondly, the receiver identifies himself or herself with the spokesperson along those categorized dimensions. Finally, the categories form the basis for selfcomparison with the spokesperson. However, the criteria for the comparison are based upon the standards of the dominant group; for example, in the USA, white Anglo-Saxon males. Also, a positive identification with the spokesperson, based on the standards of the dominant group, results in the receiver being influenced by the spokesperson. Hence, advertisers who use presenters with a positive identity along the attractiveness, trustworthiness, expertise, and accent dimensions will be expected to have a positive influence on members of the target market.

\section{Receiver}

An advertising message must be perceived before it can be transferred. Perception--the process of receiving stimuli through the senses and of interpreting them--may be determined by such audience conditions as involvement with the product or service and bilingualism. 


\section{Involvement/Audience}

Involvement has been defined in a number of different ways--ways that can be classified as having either affective or cognitive roots (Pokrywcznski, 1986).

FIGURE 2-5

RECEIVER/AUDIENCE CONDITIONS

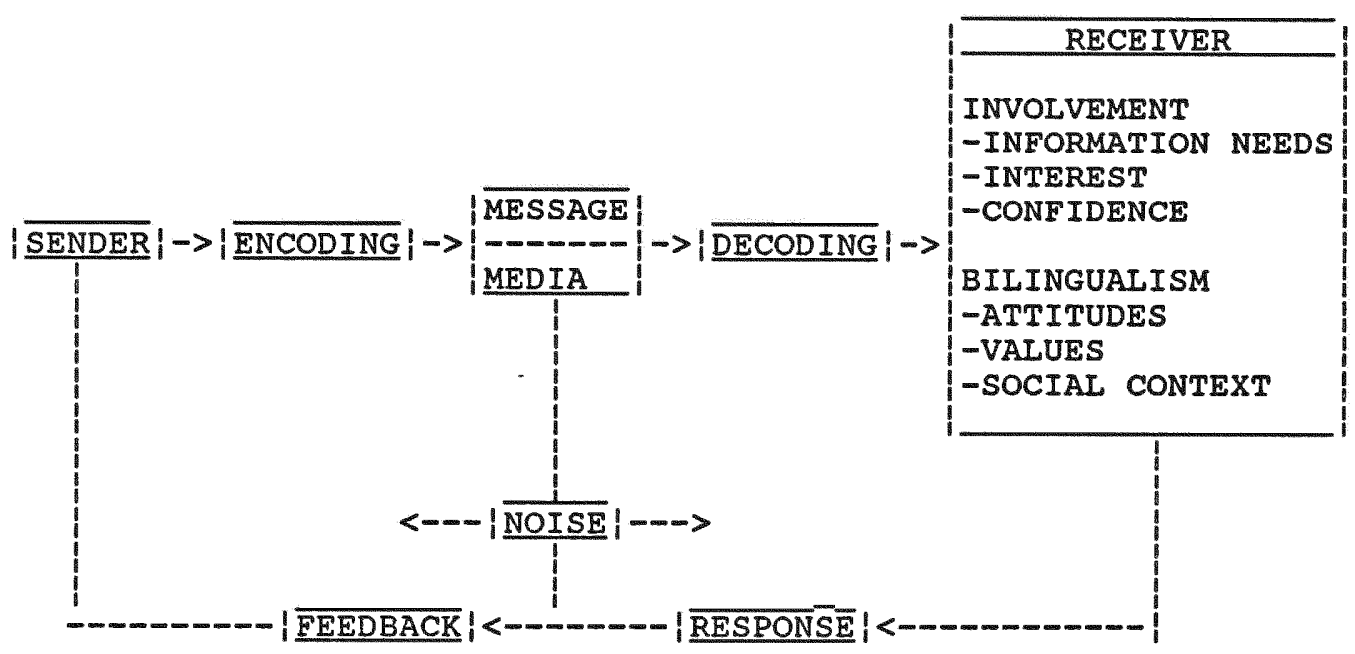

Proponents of the affectively-rooted conceptualization of involvement claim that the measurement of attitudes includes affective, cognitive, and conative components (Fishbein and Ajzen, 1975). The affective root definition focuses on an enduring drive state that is attached to an individual's central values or ego. The closer the link between an attitude and the person's central values or ego, the more the person will be ego-involved with the situation. 
Involvement, in this context, has been utilized to explain the persuasive efforts in the mass media to effect attitude change. Cognitive root definition focuses on the individual's attention, comprehension, and behavior. This approach has been used primarily in research in consumer behavior and marketing.

Involvement is defined in the present study as the level of personal importance and/or the interest evoked by a stimulus--the perceived relevance of the product (Engel, Blackwell, and Miniard, 1990; Petty and Cacioppo, 1979, 1981). Involvement is viewed as a function of the person, the object, and the situation. The level of involvement is contingent upon the perceived connection between the individual's motivating influences and the benefits presented by the object. Pokrywcznski (1986) explained this connection by the concept "bridging experiences," where individuals link past experiences to a stimulus. The author noted that there is positive relationship between number of bridge experiences and level of involvement.

Cognitive models of persuasion posit a link between spokesperson attractiveness and involvement (Eagly and Chaiken, 1984; Petty and Cacioppo, 1986a, 1986b). Under conditions of low personal involvement, spokesperson physical attractiveness may have a direct impact on the effectiveness of a persuasivè messảge (Chaiken, 1980, 1987). People are then more likely to agree with a physically attractive spokesperson than with a physically unattractive spokesperson, 
regardless of the strength of the argument. Under conditions of high personal involvement, spokesperson physical attractiveness tends to have little, if any, direct impact on the persuasiveness of a message (Chaiken, 1987; Petty and Cacioppo, 1986a, 1986b). Pokrywcznski (1986) illustrated how product characteristics and differentiation among alternatives interact with involvement to explain the processing sequence people use in various situations.

Concerning the role of visual stimuli, Swartz (1984) reported that in general there is no relationship between expertise and attractiveness; however, she did report a significant positive correlation between low expertise and high attractiveness when the television advertisement was in color.

Television advertisements which are predominantly visual are typically focused on low-involvement items (Liu, 1986). However, a more analytical model of consumer processing probably emerges in non-visual (i.e., print) advertisements which are oriented toward high-involvement items (Celsi and Olson, 1988). Capcioppo and Schumann (1983) reported that involvement is a moderating variable for advertising effectiveness. Lui (1986) noted the connection between television's distinctive visual presentation form and the creation of picture-image memory. Also, he reported that pictures are most memorable because they may consist of verbal and visual illustrations. Consequently, it is logical to speculate that picture images of television advertising should 
have a greater impact on viewers' memory than verbal statements (Lui 1986). Lui also discussed the interaction effect of information processing strategy, media characteristics, and product attribute on image memory. Two factors, he said, contribute to the general impression that TV ads represent a series of picture-images: (1) TV is a visual medium and (2) TV ads generally feature low involvement products.

\section{Bilingualism/Audience}

This section is based largely on a working paper by Laskey and Seaton (1990), in which the authors observed that although there are more bilinguals than monolinguals, there is no widely-accepted definition of bilingualism. Consequently, a variety of approaches have been used to conceptualize bilingualism. Doob (1977) focused on understanding the fluency with which bilinguals can speak or the ease with which they understand another language. Ervin (1964) focused on response time to words in native and acquired language as an indicator of language preference. Botha (1968) studied the subjective evaluation of the instructor's impressions of an individual's bilingual capabilities and considered exposure to two languages an indicator of bilingualism. Earl (1967) distinguished two forms of bilingualism according to the psychological meaning imposed by the context in which the second language was acquired: compound bilingualism and coordinate bilingualism. In the former, an individual learned the word-for-word association between two languages; in the 
latter, both languages were learned in different external and emotional contexts. Earl's conceptualization lends support to Kassarjian's (1973) assertion that meaning is obtained from the sum of one's personal and environmental experiences.

Tsalikis, Deshields, and LaTour (1991) provided two significant findings. First, a salesperson with a standard American English accent has an advantage over a salesperson who speaks Greek-accented English. This finding is consistent with the viewpoint from the linguistic and social psychology literature that spokespersons speaking in the standard accent of the audience elicit more approval ratings of credibility than spokespersons speaking a non-standard accent. Secondly, the authors found. no significant interaction between respondents' exposure to an accent and the evaluation of the accent. These two results are important because they indicate acculturation along the language pronunciation dimension. This observation is consistent with the findings of callon, Gallois, and Forbes (1983) that progressive minority group members may prefer the accent of the dominant majority, especially where it is advantageous to do so.

There was some indication that the Greek and American spokespersons were comparable along the friendly, humble, helpful, and cheerful variables. The social attractiveness construct was portrayed by these variables. The literature noted that this construct was one for which the credibility of the spokesperson may not be entirely dependent upon the host country's accent; for example, a spokesperson with an accent 
may be viewed similarly to a spokesperson with a host country's accent along the social attractiveness dimension.

\section{Audience summary}

The perception of the receiver or the audience conditions can have a significant impact on decoding or evaluating a spokesperson. Two key areas that influence receiver perception are involvement, which includes informational needs, interest, and confidence; and bilingualism, which includes attitudes, values, and social contexts.

If the argument regarding the receiver's involvement with a product is valid, it can be hypothesized that attractiveness is a component of credibility for low involvement items but not a factor for high involvement items. Thus, if expertise and attractiveness are not related to each other or are inversely related, advertisers' decision about which source dimension to emphasize becomes even more critical.

It can also be hypothesized that a presenter with an American English accent will have more influence on a bilingual audience than a presenter with a Spanish English accent. Assuming that the dominant group exhibits no accent, the bilingual audience will identify with the presenter who represents that group. Tajfel called this phenomenon social mobility or a complete acculturation into the dominant group within the society. 
The response portion of the communications model portrays the various ways the receiver or audience may give feedback to the advertiser about the impact of the advertisement (FIGURE 2-6)

The spokesperson can have cognitive, affective, and conative influence on potential consumers. These modes define and explain Lavidge and Steiner's (1961) hierarchy of advertising effects.

FIGURE 2-6

RESPONSE OPTIONS

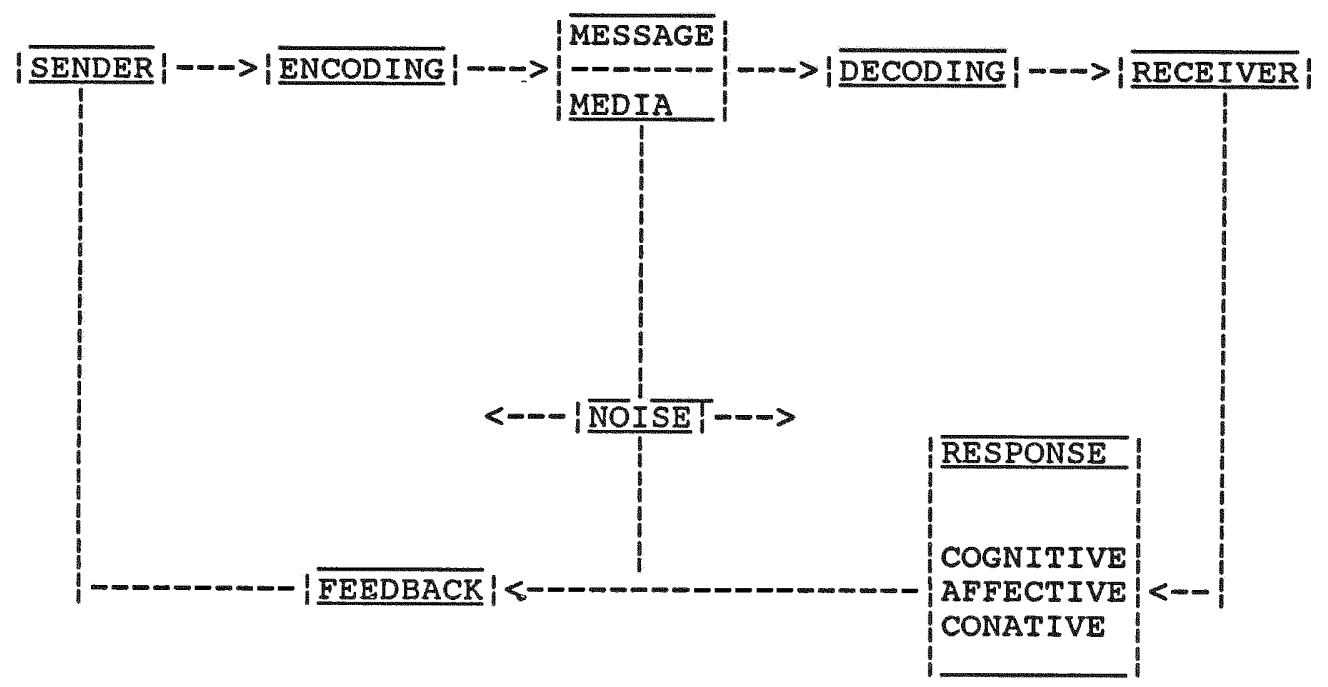

Accordingly, a buyer goes through a series of steps that lead to the purchase of an item. The first step is cognitive or gaining awareness and knowledge of a particular item. The second step is affective, developing emotion or a preference for the item; while the third step is conative, stimulating the actual purchase of the item. The buyer's presence at any 
stage depends on previous experience or knowledge of a particular item. The Lavidge and steiner (1961) hierarchy of advertising effects model, as a framework to assess advertising effectiveness, provides the basis for decisions about types of advertising message. The feasibility of an advertising decision is contingent upon the specific stage of the model the sponsor intends to impact (Eastlack 1984). Table 2-1 shows the ad model.

TABLE 2-1

ADVERTISING EFFECTIVENESS MODEL AND MEASURES

Related behavioral dimensions

CONATIVE-ACTION

-the realm of motives. Ad stimulates or direct desires.

AFFECTIVE-PERSUASION - the realm of emotions. Ads change attitudes and feeling
Movement toward purchase

PURCHASED
CONVICTION

PREFERENCE

LIKING

COGNITIVE-AWARENESS

- the realm of

thoughts. Ads

provide

information

and facts.

KূNOWLEDGE
Examples of advertising effectiveness measures

Market or sales tests split-run tests Projective techniques

Consumer Information Processing Model - Measures of Affect

* Attitude change Hedonic, Experiential Model

--Measures of Emotions

* The Warmth Monitor

* TRACE

--Physiological Arousal

Measures

* Psychogalvanometer

* Pupillometer

* ERG

* Voice-Pith Analysis

Recall test

--Burke Day-After Recall

Recognition test

--Starch

Association test

AWARENESS 


\section{Literature Review summary}

The communication processing model provides the conceptual base for the flow of information from the spokesperson to the receiver. The sequence is initiated by the spokesperson of an idea or a piece of information. The idea or information must be encoded into a message which must be transferred through the medium to the receiver. Based on the receiver's understanding of the message and the positive or negative impact the spokesperson and message may have on the receiver, the receiver decodes the message and gives feedback to the sender. The receiver's perceptions influence the manner in which the message and spokesperson are decoded. Tajfel's C.I.C. theory of individual evaluation or decoding states that a spokesperson who has a positive identity with the receiver's conception of the group in power will influence, the receiver. The cognitive, affective, or conative responses indicate the effectiveness of the sender and message. 


\section{Statement of Problem}

A number of studies have focused upon different combinations of spokesperson credibility factors, product characteristics, and audience characteristics; however, no study has presented a decoding theory to explain the relationship between these variables. Ohanian's (1991) study came closest to linking the areas by identifying three factors of spokesperson credibility-- attractiveness, trustworthiness, and expertise--and attempting to specify the relationship between them and consumers' purchase intentions. However, Ohanian's model did not use a decoding theory; it did not explicitly incorporate audience composition or the nature of the product. In addition, the results of the study indicated some inconsistencies with earlier findings in the marketing literature. Ohanian's (1991) model states that spokesperson credibility directly impacts consumers' purchase intentions, but the results of her investigation indicated that expertise was the only statistically significant construct. In other words, contrary to other findings, attractiveness and involvement are not statistical significant. Ohanian (1991) suggested that the use of gift items as high involvement products may have influenced her results. Her research suggested that identification with the attractiveness of the spokesperson is not a relevant factor for purchasing a product for someone else. As a result, she suggests that future 
research in this area consider the use of products at varying levels of involvement.

This dissertation is intended to resolve those issues raised by ohanian and to provide a decoding theory to explain the relationship between spokesperson and purchase intentions. II. Objectives of the study

The objective of this dissertation is to improve and expand Ohanian's (1991) original model by:

1) proposing a decoding theory to explain the relationship between spokesperson credibility and consumers' purchase intentions

2) adding conditions to show both a direct and indirect relationship between credibility and purchase intentions

3) including bilingual respondents to expand the population

4) testing the theory by an experimental design and covariance structure analysis that evaluate the theory's explanatory and predictive power.

The proposed decoding theory is taken from Tajfel's (1981) social categorization, social identity, social comparative (C.I.C.) theory. The decoding theory focuses on the process that an individual uses to evaluate others. Having evaluated and categorized other persons, an individual considers relevant categorical attributes that provide the basis for self-comparison. When the spokesperson is perceived as possessing the desired attributes, the receiver is likely to identify with the spokesperson (Shimp 1990).

As a group member, an individual is expected to identify and to remain with the group as long as it contributes to the 
positive aspects of social identity--aspects from which satisfaction is derived. On the other hand, if the group does not satisfy this requirement, an individual is expected to leave the group unless the move is impossible or conflicts with important values.

Since consumers' purchase intentions are contingent upon their perception of spokespersons' credibility, Tajfel's theory can be used to explain consumers' decoding or evaluation process of spokespersons. The spokespersons can be categorized by attractiveness, trustworthiness, and expertise. spokespersons who evoke positive identity on the basis of these attributes may be identified with positive aspects of individuals' self-concept and may be viewed as credible. II. Significance of The study

Managers focus on spokesperson credibility and effectiveness as a guiding principle when promoting a product or service. The more credible the spokespersons, the more positive their influence on consumers' purchase intentions. Consequently, firms are willing to spend substantial amounts of money on celebrities believed to influence consumers' purchase intentions (Aaker and Meyer, 1987; Shimp, 1990). A method and a theory that can be used to direct those huge expenditures more efficiently and effectively will make a tremendous contribution to the practitioner.

The dissertation can provide a way of explaining the relationship between the spokesperson and the receiver. As a result, a breakthrough in this area would be of significant 
value to academics and managers. Tajfel's decoding theory is proposed to provide the conceptual basis for systematic evaluation of these relationships. A model is presented which depicts the 12 hypothesized relationships. These relationships will be evaluated in an experimental setting. An interdisciplinary approach is used to explain how some of the key factors of persuasion in a marketing context contribute to the interaction of spokespersons, products, and receivers. The dissertation can therefore provide a theoretical and methodological base for selecting and evaluating the credibility of various spokespersons for different products and target audiences. 
CHAPTER IV: MODEL OF THE RELATIONSHIP BETWEEN

SPORESPERSON AND THE CONSUMER'S PURCHASE

INTENTIONS AND THE RESEARCH HYPOTHESES

\section{ModeI}

The model adapted from Ohanian (1991; FIGURE 4-1) was used to test the decoding theory.

FIGURE $4-1$

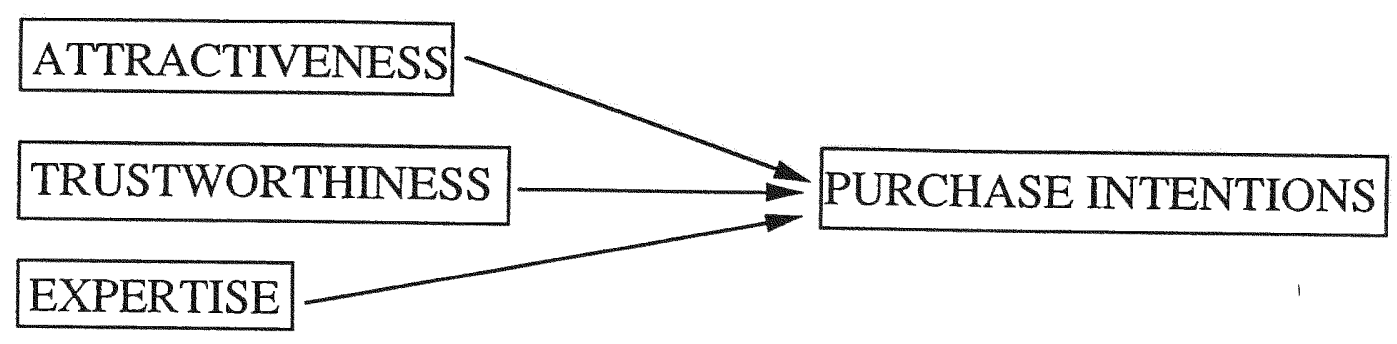

The model indicates that the impact of spokesperson's credibility constructs--attractiveness, trustworthiness, and expertise--influences the consumer's purchase intentions. These constructs are moderated by three variables involvement, audience composition, and spokesperson's accent. Although the moderating variables are not indicated in the diagram, the arrows specify the direction of the direct relationships. The model indicates that the impact of spokespersons' perceived credibility on consumers' purchase intentions is a function of spokespersons' attractiveness, trustworthiness, and expertise. The relationship between credibility and purchase decision is moderated by involvement, accent, and audience composition. 
A moderator variable modifies the form and/or strength of the relationship between a predictor and a criterion variable. Sharma, Durand, and Gur-Arie's (1981) topology (Figure 4-2) identifies and classifies the form and magnitude of the relationship between dependent and independent variables. The dimensions used for this classification express relationships between variables and interactions between or among variables.

FIGURE 4-2

TOPOLOGY OF SPECIFICATION VARIABLES

\begin{tabular}{l|c|c|} 
& $\begin{array}{c}\text { Related to } \\
\text { Criterion and/or } \\
\text { Predictor }\end{array}$ & $\begin{array}{c}\text { Not Related } \\
\text { to Criterion } \\
\text { and Predictor }\end{array}$ \\
\cline { 2 - 3 } $\begin{array}{l}\text { No Interaction } \\
\text { With Predictor }\end{array}$ & $\begin{array}{c}\text { Intervening } \\
\text { Exogenous } \\
\text { Antecedent } \\
\text { Suppressor } \\
\text { Predictor }\end{array}$ & $\begin{array}{c}\text { Moderator } \\
\text { (Homologizer) }\end{array}$ \\
\hline $\begin{array}{l}\text { Interaction } \\
\text { with Predictor } \\
\text { Variable }\end{array}$ & $\begin{array}{c}\text { Moderator } \\
\text { (Quasi moderator) }\end{array}$ & Moderator \\
& & (Pure Moderator) \\
\hline
\end{tabular}

The variables indicated in quadrant 1 are not considered moderating variables; however, the variables in the remaining three quadrants are moderating variables. The moderator variable in quadrant 2 modifies the strength of the relationship, while variables in quadrants 3 and 4 influence the form of the relationship (Sharma, Durand, and Gur-Arie, 1981). The strength of the relationship is indicated by the correlation coefficient; the form of the relationship is indicated by the regression coefficient (Arnold, 1982).

Although the moderating variables in the present study interact with the predictor variables (attractiveness, trustworthiness, and expertise), they are not interrelated. 
They are therefore considered pure moderator variables, and thus are located in quadrant 4. An indirect relationship between purchase intentions and the predictor variables (attractiveness, trustworthiness) and expertise exists. Thus including the moderating variables (involvement, audience composition, and spokespersons accent) into the model should highlight the significance of the predictor variables.

\section{Hypotheses}

Tajfel's C.I.C. theory was used to explain the impact of spokesperson's credibility on the consumers' purchase intentions. However, only the predictions regarding conditions conducive to remaining in one's consensually superior groups (Box B, p. 28) and conditions conducive to leaving one's consensually inferior groups (Box C, p. 28) were tested for the present investigation. Specifically, the dissertation focused on testing the relationships that explain the impact of attractiveness, trustworthiness, and expertise on consumers' purchase intentions, where the relationships are moderated by involvement, audience composition, and spokesperson accent.

Attractive spokespersons are more influential than unattractive spokespersons (Ohanian, 1991; Ohanian, 1990; Joseph, 1982; Chaiken, 1986; Snyder and Rothbart, 1971; Miller, 1970). Status characteristics may be diffuse and generalized across situations or specified only to unique situations (Umberson and Hughes, 1987). Physical attractiveness meets the criteria for a diffuse status 
characteristic inasmuch as high status category (e.g., white, male, attractive) is associated with greater perceived ability and skills (Webster and Driskell, 1983). In other words, attractive people may be viewed as more proficient performers of certain tasks.

According to Tajfel's C.I.C. theory, the receiver is expected to identify with the physically attractive white male as he represents a group of people the receiver considers the standard in terms of ability, skills, and status. correspondingly, where a physically attractive black man, black woman, or white woman represents a group of people the receiver considers a desirable standard, the receiver identifies with that spokesperson. As a result, attractive spokespersons are expected to be viewed more favorably (i.e., receive higher rating) than unattractive spokespersons.

H1: A SPOKESPERSON WITH PERCEIVED ATTRACTIVENESS WILL EVORE MORE FAVORABLE PURCHASE INTENTIONS THAN A SPORESPERSON LACRING IN ATTRACTIVENESS.

Trustworthiness of the spokesperson helps the presenter to change the recèiver's outlook. Studies show that trustworthy presenters are more influential than presenters lacking in trust (Miller and Baseheart, 1969; McGinnies and Ward, 1980). Tajfel's theory recognizes that spokesperson trustworthiness is a desirable and positive trait. Consequently, receivers who view the spokesperson trustworthy can positively identify with that spokesperson and associate the spokesperson with a desirable group. As a result, respondents are more likely to purchase a service from a 
spokesperson who is trustworthy than from one who is not trustworthy.

H2: A SPOKESPERSON WITH PERCEIVED TRUSTWORTHINESS WILL EVORE MORE FAVORABLE PURCHASE INTENTIONS THAN A SPORESPERSON LACKING IN TRUSTWORTHINESS.

Expertise, a perceived rather than an absolute phenomenon, refers to the knowledge, experience, or skills demonstrated by a spokesperson for a specific issue (Shimp, 1990). A presenter who is perceived as having expertise will be more persuasive than a presenter who is perceived as lacking in expertise (Wadset and Davenport, 1974). Ohanian (1990) recalled that a number of investigations have shown that expertise has a positive influence on attitude change. Tajfel's theory views expertise as a spokesperson characteristic that the receiver can use to evaluate the spokesperson. Consequently, the receiver would identify positively with a spokesperson who possesses expertise. A spokesperson with expertise is therefore expected to be more influential than a spokesperson who is lacking in expertise.

H3: A SPOKESPERSON WITH PERCEIVED EXPERTISE WILL EVOKE MORE FAVORABLE PURCHASE INTENTIONS THAN A SPOKESPERSON LACKING IN EXPERTISE.

Cognitive models of persuasion have suggested that the role spokesperson attractiveness portrays is multifaceted (Eagly and Chaiken, 1984; Petty and Cacioppo, 1986a, 1986b). For example, under conditions of low personal involvement, concerning matters of little consequence, presenters' physical attractiveness appear to have a direct influence on the effectiveness of a persuasive message (Chaiken, 1980, 1987). 
Low involvement matters relate to peripheral rather than to central route information processing (Petty and Cacioppo, $1986 \mathrm{a}, 1986 \mathrm{~b})$. Consequently, where a low involvement product is the focus, individuals are more likely to agree with a physically attractive spokesperson than with a physically unattractive spokesperson regardless of the strength of the argument (Pallak, 1983). However, for an issue that has greater personal consequence, presenters' physical attractiveness tends to have little, if any, direct influence on the persuasiveness of a message.

Another important dimension of source attractiveness is represented by similarity, familiarity, and liking. A source is considered attractive when the receiver shares a sense of similarity or familiarity, or when the receiver simply likes the source. ' Consequently, persuasion through an identification process may be based on any attribute the receiver finds attractive. Attractive attributes may include intellectual skills, personality properties, lifestyle characteristics, and so on. However, the importance of the issue influences the relative weight the receiver places on the attractiveness of spokesperson. For example, a physician's competence is more important than his or her attractiveness when the receiver is determining who should perform a surgical procedure. Thus, depending on the importance of a product or service, respondents are not expected to base their judgement solely on attractiveness. Rather, attractiveness may be substituted for more critical 
attributes as trustworthiness and expertise (Baker and Churchill, 1977; Petty and Cacioppo, 1986).

H(0) 4: THERE WILL BE NO INTERACTION BETWEEN VARIOUS LEVELS OF ATTRACTIVENESS AND INVOLVEMENT ON CONSUMER PURCHASE INTENTIONS

Based on the logic of $\mathrm{H}(0) 4$ the importance of the service to the receiver will determine the role of trustworthiness in receivers' decision-making process. Tajfel (1982) views trustworthiness as one of the factors receivers can use to evaluate spokespersons. However, the importance of this factor is determined by receivers' perception of the service. Thus, respondents who view the service as a low involvement item are expected to base a heavy proportion of their evaluation on the periphery of the attribute; for example, a perception of trustworthiness (Petty and Cacioppo, $1986 \mathrm{a}, 1986 \mathrm{~b})$. On the other hand, respondents who view the item as high involvement will base their evaluation on characteristics reflected in the content and delivery of the message; for example; expertise.

H(0) 5: THERE WILL BE NO INTERACTION BETWEEN VARIOUS LEVELS OF TRUSTWORTHINESS AND INVOLVEMENT ON CONSUMER PURCHASE INTENTIONS.

Using the same logic, the importance of the service to receivers will also determine the role of expertise in receivers' decision-making process. Again, Tajfel's theory views expertise as a characteristic that receivers can use to evaluate spokespersons. The importance of this characteristic is based on receivers perception of the service. 
Respondents who view a service as a high involvement item are expected to be more concerned with the salesperson's expertise than are respondents who view the service as a low involvement item (Petty and Cacioppo, 1986a, 1986b).

\section{H(0) 6: THERE WILL BE NO INTERACTION BETWEEN VARIOUS LEVELS OF EXPERTISE AND INVOLVEMENT ON CONSUMER PURCHASE INTENTIONS.}

As reported earlier, source attractiveness is represented by similarity, familiarity, and liking. Furthermore, a source is considered attractive when the receiver shares a sense of similarity or familiarity, or when the receiver simply likes the source. As a result, persuasion through an identification process may be based on any attribute the receiver finds attractive. Attractive attributes may include intellectual skills, personality properties, lifestyle characteristics, spokesperson's accent and so on.

Speech style, including accent, appears to have a powerful impact on the ratings of respondents over a broad range of presenter characteristics (Lambert, 1967; Labov, 1972b; Labov, 1972C; Giles and Sassoon, 1983; Bradac and Wisegarver, 1984). A number of investigations in Englishspeaking countries (e.g., the United States, Canada, Britain, and Australia) found that presenters with standard accents or dialects were perceived to exhibit more traits of (a) competence, exemplified by intelligence, confidence, ambition, and industriousness; and (b) status, exemplified by prestige and professionalism (Edwards, 1982). Speech characteristics 
also perform a central role in evaluating an individual's race, age, social class, profession, and so on (Garcia, 1984). Tajfel's (1972) theory of social categorization was used to explain how individuals use speech characteristics to infer social category.

Caucasian Americans are considered more favorably for they represent mainstream standards (Webster and Driskell, 1983; Eagly and Wood, 1985; Cohen and Roper, 1972). Tajfel's theory suggests that characteristics of Caucasian American respondents reflect conditions conducive to remaining in one's group; that is, Caucasian Americans are consensually viewed as members of superior groups. Consequently, Caucasian American respondents are expected to view spokespersons with no accent more favorably than they would view spokespersons with accents (e.g., Cuban or Nicaraguan English accents). On the other hand, characteristics of Cuban Americans and other "nonstandard" groups reflect conditions conducive to leaving one's group since nonstandard or minority persons may be viewed as members of consensually inferior groups. Besides, the ability for "nonstandard" individuals to leave the inferior group and identify with Caucasian American standards is nonproblematic if social mobility factors such as spokespersons' accent and attractiveness form the basis of evaluation. Thus, "nonstandard" respondents are also expected to view spokespersons with no accent more favorably (i.e., more attractive) than spokespersons with an accent (e.g., Cuban or Nicaraguan English accent). 
H(0) 7: THERE WILL BE NO INTERACTION BETWEEN VARIOUS LEVELS OF ATTRACTIVENESS AND ACCENT ON CONSUMER PURCHASE INTENTIONS.

Based on the logic of $\mathrm{H}(0) 7$, Tajfel's theory predicts that Caucasian American respondents will view spokespersons with a standard American accent more favorably (i.e., more trustworthy) than spokespersons with a cuban or Nicaraguan English accents. In addition, Tajfel's theory predicts that Cuban Americans and other "nonstandard" groups will view spokespersons with a standard American accent more favorably than spokespersons with a Cuban or Nicaraguan English accent. Again, the ability for the nonstandard individual to leave the group is nonproblematic if social mobility factors such as accent and trustworthiness are used as the basis of evaluation.

H(O) 8: THERE WILL BE NO INTERACTION BETWEEN VARIOUS LEVELS OF TRUSTWORTHINESS AND ACCENT ON CONSUMER PURCHASE INTENTIONS.

Again, using the same logic, Tajfel's theory predicts that Caucasian.American respondents will view spokespersons with no accent more favorably (more of an expert) than spokespersons with a Cuban or Nicaraguan English accent. Furthermore, Tajfel's theory predicts that Cuban Americans and other minority groups will view spokespersons with no accent more favorably than spokespersons with a Cuban or Nicaraguan English accent. Again, the ability for the minority individual to leave the group is not a critical issue if social mobility factors such as accent and expertise form the basis of evaluation. 
H(O) 9: THERE WILL BE NO INTERACTION BETWEEN VARIOUS LEVELS OF EXPERTISE AND ACCENT ON CONSUMER PURCHASE INTENTIONS.

There is no significant interaction between the respondents' exposure to accent and the evaluation of the accent (Tsalikis, Deshields, and LaTour 1991). This finding is important because relating credibility to the language standard of the new host country indicates total acculturation along the language pronunciation dimension of the new environment. This observation is consistent with the finding of Callon, Gallois, and Forbes (1983) that ethnic minority groups are inclined to identify with the accent of the dominant group.

As noted earlier, physically attractive spokespersons are more influential than unattractive spokespersons (Ohanian, 1991; Ohanian, 1990; Joseph, 1982; Chaiken, 1986; Snyder and Rothbart, 1971; Miller, 1970). Also, the receiver is expected to identify with the physically attractive white male who represents the standard group with reference to ability, skills, and status. Since this investigation is using a physically attractive and a physically unattractive white male, Tajfel's theory would expect monolingual or bilingual receivers to evaluate each of these spokespersons on the attractiveness construct and accent variable. Tajfel's theory would predict that an attractive spokesperson with no accent will be viewed more favorably than an attractive spokesperson with an accent. Consequently, hypotheses 10(0) A through $10(0) D$ were tested for (1) the three-way interaction effect of 
the speaker's accent, attractiveness, and the language speaking capability of the audience; (2) two two-way interaction effects of the speaker's accent and the speaking capability of the audience, and the speaker's attractiveness, and the speaking capability of the audience; and (3) the main effect, specifying a difference between the purchase intentions of an English speaking and a bilingual audience.

H10(0)A: THERE WILL BE NO DIFFERENCE IN THE INTERACTION BETWEEN ATTRACTIVENESS AND ACCENT ON THE PURCHASE INTENTIONS OF AN ENGLISH SPEAKING OR BILINGUAL AUDIENCE.

H10(0)B: THERE WILL BE NO DIFFERENCE IN THE IMPACT OF THE ACCENT OF THE SPEARER ON PURCHASE INTENTIONS FOR AN ENGLISH SPEARING OR BILINGUAL AUDIENCE.

H10(0) C: -THERE -WILL BE NO DIFFERENCE IN THE IMPACT OF THE ATTRACTIVENESS OF THE SPEARER ON PURCHASE INTENTIONS FOR AN ENGLISH SPEARING OR BILINGUAL AUDIENCE.

H10(0)D: THERE WILL BE NO DIFFERENCE IN PURCHASE INTENTIONS BETWEEN AN ENGLISH SPEARING AND BILINGUAL AUDIENCE.

Using the logic for $H(0) 10$, Tajfel's theory also predicts that a non-accented, trustworthy spokesperson will be viewed more favorably than an accented trustworthy spokesperson.

H11(0) A: THERE WILL BE NO INTERACTION BETWEEN ACCENT AND TRUSTWORTHINESS ON PURCHASE INTENTIONS FOR EITHER AN ENGIISH SPEARING OR BILINGUAL AUDIENCE.

H11(0)B: THERE.WILL BE NO DIFFERENCE IN THE IMPACT OF THE TRUSTWORTHINESS OF THE SPEARER ON THE PURCHASE INTENTIONS FOR EITHER AN ENGLISH SPEARING OR BILINGUAL AUDIENCE. 
Again, using the same logic, Tajfel's theory predicts that the spokesperson with expertise and no accent will be viewed more favorably than the spokesperson with expertise and an accent.

H12(0)A: THERE WILL BE NO INTERACTION BETWEEN ACCENT AND EXPERTISE ON PURCHASE INTENTION FOR EITHER AN ENGLISH SPEAKING OR BILINGUAL AUDIENCE.

H12(0)B: THERE WILL BE NO DIFFERENCE IN THE IMPACT OF THE EXPERTISE OF THE SPEAKER ON PURCHASE INTENTIONS FOR EITHER AN ENGLISH SPEARING OR BILINGUAL AUDIENCE.

\section{Summary}

This chapter contains the model of the relationships for the constructs and moderator variables, and the research hypotheses. Tajfel's theory of decoding provides the foundation for specifying the hypothesized relationships in the model. The next chapter describes the research methodology for the study. 


\section{CHAPTER V. RESEARCH METHODOLOGY}

This chapter presents the methodology and gives the methodological assumptions of the study. It outlines the experimental design, and analytical techniques used to test the research hypotheses. Chapter five also delineates the sampling rationale and collection procedures and presents the measuring instrument.

I. Pre-Test for Spokesperson's Attractiveness and Accent

In experimental conditions, physical attractiveness is typically decided by a representative panel of judges who evaluate the physical attributes of one or more stimulus individuals (Joseph 1982). If a significant number of judges designate a stimulus individual as physically attractive, then, for the purpose and context of the study, that stimulus individual is defined as physically attractive (Berscheid and Walster, 1974). Joseph (1982) reported that stimulus persons obtaining the highest and lowest average evaluations are then chosen to symbolize high and low degrees of physical attractiveness in subsequent experiments. The legitimacy of this technique has been validated with evidence from a variety of investigations indicating that physical attractiveness evaluations of stimulus persons tend to be identical regardless of the rater's sex, age, geographic region, and socioeconomic class (Kopera, Maier, and Johnson, 1971; Cavior and Dokecki, 1971; Hiffe, 1960).

Two procedures were used to select the spokespersons for this study. The first procedure identified one attractive and 
one unattractive spokesperson (male) from a list of pictures containing 10 persons by having a representative segment of the population, to be used in the study--undergraduate students, rate each person on a 7-point attractivenessunattractiveness scale. An additional measure of attractiveness of the two selected persons was derived from 30 respondents in another segment on the target population (FIUstudents). Gender, and ethnicity, and culture were taken into account by noting demographic information of the population. Video tapes were used to show the spokepersons to this set of respondents. An analysis of the responses indicated that the attractive spokesperson had a mean of 6.2 and the unattractive spokesperson had a mean of 3.1 on the 7point scale $\left(7^{\circ}\right.$ is the highest rating for attractiveness). This procedure was use to insure that respondents would evaluate the video tapes of the spokespersons in the same way that the pictures were rated--video tapes were used for the study.

The second procedure used four spokespersons attractive and 2 unattractive). These spokespersons were, also, chosen from a list of 10 males who were rated on a 7point attractiveness-unattractiveness scale by a random sample of the population (FIU students) that would be used to, eventually, evaluate the spokesperson. Based on the results of the survey three males were rated as attractive and three were rated as unattractive. An additional measure of attractiveness-unattractiveness was derived from 67 ( 28 males 
and 39 females) respondents in another segment of the target population (FIU--students). Gender, and ethnicity, and culture were taken into account and video tapes were used for the respondent to make the evaluation.

A two way ANOVA with a repeated measure of one factor (level of attractiveness) for the four spokespersons indicated there was a statistically significant difference (F-Value 45.56, $\mathrm{P}<0.0001$ ) between the attractiveness of the spokespeople (Table 5-1).

$$
\text { TABLE }-5-1
$$

REPEATED MEASURES ANALYSIS OF VARIANCE

REPEATED MEASURES FOR LEVELS OF ATTRACTIVENESS

\begin{tabular}{|c|c|c|c|c|c|}
\hline STATISTIC & VALUE & $F$ & NUM DF & \multicolumn{2}{|c|}{ DEN DFPr $>F$} \\
\hline WILKS' LAMBDA & 0.32 & 45.56 & 3 & 63 & 0.0001 \\
\hline $\begin{array}{l}\text { PILLAI'S TRACE } \\
\text { HOTELLING-IAWLEY }\end{array}$ & 0.69 & 45.56 & 3 & 63 & 0.0001 \\
\hline $\begin{array}{l}\text { TRACE } \\
\text { ROY'S GREATEST }\end{array}$ & 2.17 & 45.56 & 3 & 63 & 0.0001 \\
\hline ROOT & 2.17 & 45.56 & 3 & 63 & 0.0001 \\
\hline
\end{tabular}

A MANOVA for the interaction between attractiveness and sex of the evaluator indicated that the interaction was statistically significant (F-Value 3.21, $\mathrm{P}<0.03$ ) (Table 5-2). Scheffe's test indicated that male and females means were the following 5.05 and 3.54 respectively. 


$$
\text { TABLE - } 5-2
$$

MANOVA TEST CRITERIA AND EXACT F STATISTICS FOR THE HYPOTHESIS OF NO ATTRACTIVENESS*SEX INTERACTION

\begin{tabular}{|c|c|c|c|c|c|}
\hline STATISTIC & VALUE & $\mathbf{F}$ & NUM DF & DEN DF & $\mathrm{Pr}>\mathrm{F}$ \\
\hline WILKS' LAMBDA & 0.87 & 3.21 & 3 & 63 & 0.029 \\
\hline $\begin{array}{l}\text { PILLAI'S TRACE } \\
\text { HOTELLING-LAWLEY }\end{array}$ & 0.13 & 3.21 & 3 & 63 & 0.029 \\
\hline $\begin{array}{l}\text { TRACE } \\
\text { ROY'S GREATEST }\end{array}$ & 0.15 & 3.21 & 3 & 63 & 0.029 \\
\hline ROOT & 0.15 & 3.21 & 3 & 63 & 0.029 \\
\hline
\end{tabular}

A panel of six judges--three Cuban Americans and three Nicaraguan Americans--were used to determine an accent recognition factor. This procedure determined whether the panel could distinguish a Cuban English accent from a Nicaraguan English accent. Four of the six judges were able to recognize the difference. As a result, two Cuban American and two Nicaraguan American accents were selected for the study. Although the above procedure for selecting the American English accents was not used, a screening process was conducted to select two American English accents that were clear and appeared, in the judgement of the researcher, standard. Consequently, these six accents were used for the study (2-American English, 2-Cuban English, and 2-Nicaraguan English). 
II. Questionnaire

In order to conduct the study a 15-item semantic differential scale for source credibility, 3-semantic differential scales measuring purchase intentions, 3 scales measuring voice characteristics of the spokesperson, 20-item semantic differential scale to measure low/high involvement, and 14 classification questions (Appendix A). The 15-item semantic differential scale adjectives represent the three underlying dimensions of credibility: attractiveness, trustworthiness, and expertise (Ohanian, 1991).

TABLE $-5-3$

15-ITEM SEMANTIC DIFFERENTIAL SCALE ADJECTIVES

Attractiveness

Trustworthiness Expertise

-Attractive

-Dependable

-Expert

- Classy

-Honest

-Experienced

-Beautiful

-Reliable

-Elegant

-Sexy

-Sincere

-Knowledgeable

-Trustworthy

-Qualified

-Skilled

The 15 adjectives were selected from Ohanian (1990). These adjectives were also used in several studies in the Social Psychology literature (Brennan, Ryan and Dawson, 1975; Brennan and Brennan, 1981, 1983; Seggie, Fulmizi and Stewart, 1982; Callan, Gallois and Forbes, 1983; Garcia, 1984; Woolard, 1984; Brown, Giles and Thakerar, 1985; Foon, 1986; Kalmar, Young and Hong, 1987). 
III. Measurement of Terms

A 7-point scale measured the 15-item semantic differential scale adjectives, with (1) representing the negative pole and (7) representing the positive pole.

Zaichkowsky (1985) developed a 20-item affectively-based semantic differential involvement scale to measure products and advertising media. The scale is contingent upon the personal relevance of the product to individuals' needs, values, and interest (Pokrywcznski, 1986). Because the instrument is sensitive to within product variation, it will detect respondents who view the service as high involvement and low involvement. A 7-point scale was utilized to measure a 20-item semantic differential scale adjectives for involvement, with (1) for low involvement and (7) for high involvement. A total of 20 items range from a low of 20 to a high of 140 (Zaichkowsky 1985).

The fourteen classification questions provided some insight about respondents' sex, exposure to accent and other languages, etc.

In order to operationalize the constructs of attractiveness, trustworthiness, expertise, and involvement, the upper quartile (25\%) was used to represent the high level of these constructs, while the lower quartile (25\%) was used to represent the low level of these constructs. This approach was used to insure that the respondent's perception of the high and low levels of the constructs or moderating variables were being compared. Since the purchase intentions construct 
was the dependent variable and it was used to measure the effect of the independent variables, the average of the three indicator variables that was used to form the construct was employed (Cronbrach Alpha for the purchase intention construct was .93). The responents perception of the presenter's accent and the audience language speaking capability was provided (directly) from the respondent's answers to the fourteen classification questions. As a result, the respondent's score at the upper $25 \%$ quartile or the lower $25 \%$ quartile, provided the following operational definitions for the constructs and variables that were used for this investigation:

Spokesperson Physical Attractiveness--operationalized by using five-item Semantic Differential scale: attractiveness $=$ (attractive + classy + beautiful + elegant + sexy)/5--high attractiveness $>=4 ;$ low attractiveness $<=1.8$ (Ohanian, 1991).

Spokesperson Trustworthiness--operationalized by using five item Semantic Differential scale: trustworthiness $=$ (dependable + honest + reliable + sincere + trustworthy) /5--high expertise $>=5$; low expertise $<=3$ (Ohanian, 1991).

Spokesperson Expertise--operationalized by using a five item Semantic Differential scale: expertise = (expert + experienced + knowledgeable + qualified + skilled)/5-high expertise >= 4; low expertise < 2 (Ohanian, 1991).

Involvement--the level of perceived personal importance and/or the interest evoked by a stimulus within a particular situation--Engel, Blackwell, and Miniard 1990--(operationalized by using a 20-item semantic differential scale: involvement $=(20$ items $) / 20--\mathrm{high}$ involvement $>=6$ and low involvement $<=4.4$ (Zaichkowsky, 1985).

Presenter's Accent--no accent (i.e., English), Cuban Accented English, and Nicaraguan Accented English (a panel of 3-Cubans and 3-Nicaraguans were used to determine the recognizability of the Cuban English and Nicaraguan English accents). 
Audience bilingualism--English speaking or Bilingual (ability. to speak English and at least Spanish) respondents (operationalized by identifying the respondent's native language on the background section of the questionnaire; Doob 1957).

Purchase Intentions--were operationalized by using a three item semantic differential scale: purchase intentions $=$ (inquiring purchasing + consider purchasing + actual purchasing)/3: (Ohanian, 1991).

\section{Reliability of the Measures}

Although Ohanian (1990) tested the reliability of the instrument for her study, reliability was reassessed for this investigation. This was a necessary step since the sample design for this study was different from that of ohanian. Ohanian (1991) assessed the impact of celebrities on the purchase intentions. of nonstudents for a gift buying situation. The present study was targeted to both students and non-students. It featured a personal use service to be purchased from a noncelebrity spokesperson who may or may not speak with an accent. In addition, over 40 percent of the subjects in the present sample were bilingual and approximately 45 percent of the subjects' parents were born in a country outside the U.S.A. The variables loading on the factors in this study may vary from the results of the ohanian (1991) investigation because of these differences in sample population and spokespersons.

Two techniques were used to assess the internal consistency of the constructs: exploratory factor analysis and Cronbach alphas. Churchill (1979) noted that exploratory factor analysis is an excellent technique for "purifying" the 
scale after Cronbach alphas have been measured. The Cronbach alphas for the key constructs in the study were .89 for expertise, .86 for trustworthiness, and .83 for attractiveness. According to Nunnally (1978) the reliability measures were. acceptable; however an exploratory factor analysis indicated that three of the indicator variables had overlapping factor structures. The three variables had mixed factor loadings on the expertise construct. The reliable and dependable variables had high loadings on the predicted trustworthiness construct and on the unpredicted expertise construct; classy had high loadings on the predicted attractiveness construct and on the unpredicted expertise construct (see TABLE 5-4).

Joreskog and Sorbom (1989) noted that multiple loadings on constructs could be resolved in LISREL by freeing (letting) the variables to load on the unpredicted constructs to obtain a better fitting model, if it could be justified theoretically. Another approach to the problem is to eliminate the overlapping variables to obtain an unambiguous conceptual definition of the factors or constructs (Churchill, 1979). The latter approach was used. Thus, the scale was "purified" by dropping two variables from the trustworthiness construct and one from the attractiveness construct. This procedure obtained non-overlapping factor structures. Table 5-5 presents a summary of the reliability measures for the study. 


\section{TABLE 5-4--FACTOR LOADINGS FROM EXPLORATORY FACTOR ANALYSIS EXPERTISE TRUSTWORTHINESS ATTRACTIVENESS PURCHASE INTENTIONS}

FACTOR 1 FACTOR 2 FACTOR 3 FACTOR 4

\begin{tabular}{lllll} 
Experienced & .77 & .17 & .09 & .19 \\
Qualified & .70 & .31 & .17 & .23 \\
Skilled & .65 & .30 & .24 & .15 \\
Expert & .64 & .15 & .13 & .27 \\
Knowledgeable & .62 & .31 & .17 & .16 \\
\hline & & & & .16 \\
Trustworthy & .32 & .69 & .11 & .22 \\
Sincere & .22 & .68 & .13 & .20 \\
Honest & .16 & .64 & .19 & .17 \\
Reliable & $.46 *$ & $.57 *$ & .14 & .21 \\
Dependable & $.45 *$ & $.46 *$ & .75 & .09 \\
Attractive & .10 & .20 & .73 & .11 \\
Sexy & .11 & .03 & .72 & .04 \\
Beautiful & .06 & .22 & .57 & .10 \\
Elegant & .18 & .04 & & .20 \\
Classy & $.43 *$ & .11 & .15 & .81 \\
Consider & .28 & .29 & .17 & .79 \\
Inquire & .27 & .26 & .18 & .69 \\
Purchase &. .34 & .28 & &
\end{tabular}

* Overlapping variables--loading on two structures (within $+/-.10$ ) 


\section{TABLE 5-5--RELIABILITY MEASURES FOR THE STUDY}

Coeff. Alpha Factor

Constructs/Vars Items

EXPERTISE

-experienced

-qualified

-expert

-skilled

-knowledgeable

TRUSTWORTHINESS

-trustworthy

-sincere

-honest

ATTRACTIVENESS

-attractive

- sexy

-beautiful

-elegant

PURCHASE INTENTION

-purchase

- consider

-inquire

4

.82

.75

.73

.72

.57

3

.93

.70

.82

.79
5

standardized Loadings Eigenvalue

.89

$2 \cdot 91$
.79

.72

.68

.65

.63

.82

1.77

3

.71

.69

.66

2.17

2.20

The reliability of the instrument was also measured for each spokesperson. Cronbach alphas were calculated for each presenter on the attractiveness and accent dimensions, and on the constructs that represented the underlying dimension of credibility (attractiveness, trustworthiness, and expertise) and for purchase intentions. The cronbach alphas for presenter's attractiveness are in Table 5-6, while the 
Cronbach alphas for presenter's accent are in Table 5-7. A11 of the Cronbach alphas in Tables 5-6 and 5-7 are satisfactory (Nunnal1y, 1978).

TABLE $-5-6$

CRONBACH ALPHAS FOR PRESENTER

CONSTRUCTS STANDARDIZED CRONBACH ALPHAS FOR PRESENTERS

1st Att 2nd Att 3rd Att 1st Unatt 2nd Unatt Audi

ATTRACTIVENESS

--attractive
--sexy
--beautiful
--elegant

$\begin{array}{llllll}.78 & .77 & .78 & .71 & .81 & .74\end{array}$

TRUSTWORTHINESS

--trustworthy

--sincere

-honest

.82

.88

.77

.78

.88

.80

EXPERTISE

--experience

-qualified

--expert

--skilled

--knowledgeable

$$
.88
$$

.89

.90

.90

.90

.90

PURCHASE INTENTIONS

--purchase

--consider

--inquire

.94

.93

.91

.92

.94

.90

AVERAGE

.85

.88

.86

.97

.92

LEGEND

1st att-attractive presenter 1 1st unatt-unattractive presenter 1 2nd att-attractive presenter 2 2nd unatt-unattractive presenter 2 $3 r d$ att-attractive presenter 3 audi--audio-only presentation 


\section{TABLE $--5-7$ \\ CRONBACE ALPHAS FOR ACCENTS}

CONSTRUCTS

STANDARDIZED CRONBACH ALPHAS FOR ACCENTS

'1st Amŕ 2nd Amr 1st NiC 2nd Nic 1st Cub 2nd Cub

ATTRACTIVENESS

--attractive
--sexy
--beautiful
--elegant

.83

.82

.78

.87

.83

.79

TRUSTWORTHINESS

--trustworthy
--sincere
--honest

.81

.84

.76

.83

EXPERTISE

--experience

- qualified

--expert

- skilled

--knowledgeable

$$
.88
$$

.89

.86

.87

.88

PURCHASE INTENTIONS

--purchase

--consider

--inquire

.92

.93

.92

.89

.89

AVERAGE

$$
.88
$$

.88

.87

.89

.87

.85

\section{LEGEND}

1st Amr--American Accent 1

2nd Amr--American Accent 2

1st Nic--Nicaraguan English Accent 1

2nd Nic--Nicaraguan English Accent 2

1st Cub--Cuban English Accent 1

2nd Cub--Cuban English Accent 2 
The variation in the dependent variable (purchase intentions) can be explained by the independent variables (constructs) of the audience's perception of spokesperson's attractiveness, trustworthiness, and expertise. Furthermore, these constructs are moderated by the audience's perception of the spokesperson's accent, importance of the item (involvement), and the language speaking capability of the audience. Although the manipulation check for the spokesperson's attractiveness construct and the accent moderating variable was performed, the manipulation check for the trustworthiness and expertise constructs could not be preformed directly. However, Tsalikis, Deshields, and LaTour (1991) used the trustworthiness and expertise constructs to evaluate respondents perception of spokespersons accents. The perceptions of the importance of the item (involvement construct) was based on the instrument used by zaichkowsky (1985).

The attractiveness of the spokespersons, selected for the study, were tested for the different perceptions of the respondents across two categories: spokesperson high attractiveness and spokesperson low attractiveness. The categories of spokespersons were based upon the pre-selected classification of the spokespersons (three spokespersons who were considered to have high attractiveness and two spokespersons who were considered to have low attractiveness). A successful manipulation test would show that respondents 
could distinguish the spokespersons with high and low attractiveness according to the pre-selected classifications-while controlling for accent--(a statistically significant difference across the two categories existed). The results of the test is showed in the Table 5-8. The SAS program was used with GLM and Type III SS option. Also, the Duncan test for the means was performed. The analysis indicated that a statistically significant difference existed between high and low spokesperson's attractiveness (F-Value 221.03, $\mathrm{P}<0.0001$ ). The statistically significance of the difference between the high and low attractiveness of the spokesperson is, also, reflected in the Duncan test of the means (high spokespersons' attractiveness mean of 3.56 , low spokespersons' attractiveness of 2.28 ).

TABLE -- 5-8

ANALYSIS OF VARIANCE FOR HIGH AND LOW ATTRACTIVENESS OF THE SPOKESPERSON

$\begin{array}{lccccc}\text { Source } & \text { D.F. } & \text { Type III SS } & \text { Mean Squares } & \text { F/P-VALUE } \\ \text { Attractiveness } & 1 & 383.58 & 383.58 & 221.03 / 0.0001 \\ \text { R-Square .18 } & \text { Root MSE } 1.32 & & \text { Attractiveness Mean 3.06 }\end{array}$

Duncan Grouping

Attractiveness

HIGH ATTRACTIVENESS

LOW ATTRACTIVENESS

$\begin{array}{crr}\text { Mean } & \text { Sample } & \text { Lett } \\ 3.55 & 607 & \text { A } \\ 2.28 & 386 & \text { B }\end{array}$

Means with the same letter are not significantly different. 
The hypotheses of this investigation focuses on dependent variable--consumer's purchase intentions, and the independent variables--spokesperson's attractiveness, trustworthiness, and expertise. An additional impact on consumer's purchase intentions was taken into account by evaluating the impact of three more independent variables: consumer's involvement, spokesperson's accent, and language speaking capability of the audience (moderating variables) on the spokesperson's attractiveness, trustworthiness, and expertise. Also, an assessment was made of the impact on the consumer purchase intentions from the independent variables of an audio-only (no visual spokesperson) segment of accents, consumer's involvement, and the language speaking capability of the audience.

A $3 \times 3 \times 2$ factorial design portrayed in Figure 5-1 was used to specify the dimensions and levels for the study (attractiveness 3--levels; accent--3 levels; and audience 2 levels). Consequently, there were 18 treatments for the study. The assumption is that an English speaking or Bilingual audience will vary their purchase intentions for an item based on their perceptions of: 1) high or low attractiveness of a spokesperson (or no spokesperson's attractiveness--audio-only presentation) that speaks with an 2) accent (American English or Cuban English or Nicaraguan English). That is, the stimuli of spokesperson's attractiveness and accent were exposed (manipulated) to an 
English speaking and Bilingual audience to evaluate how their perception of these spokespersons will vary their purchase intentions for an item.

FIGURE 5-1

$3 \times 3 \times 2$ FACTORIAL DESIGN

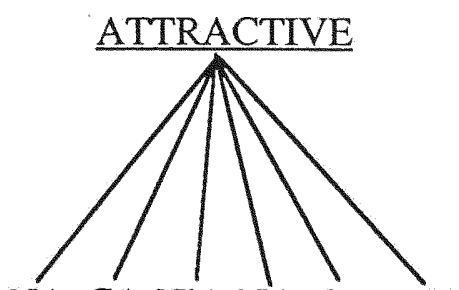

NA CA NiA NA CA NiA
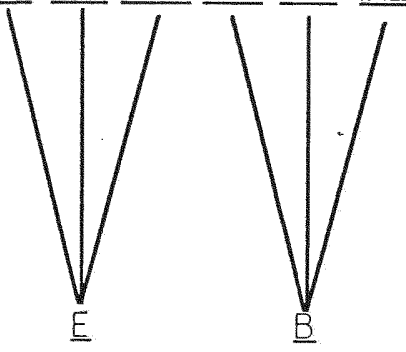

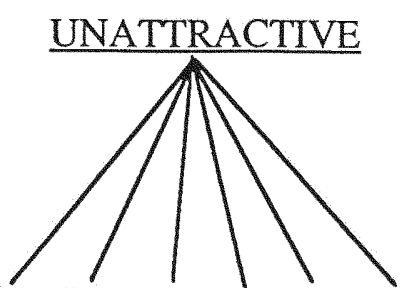

NA CA NiA NA CA NiA
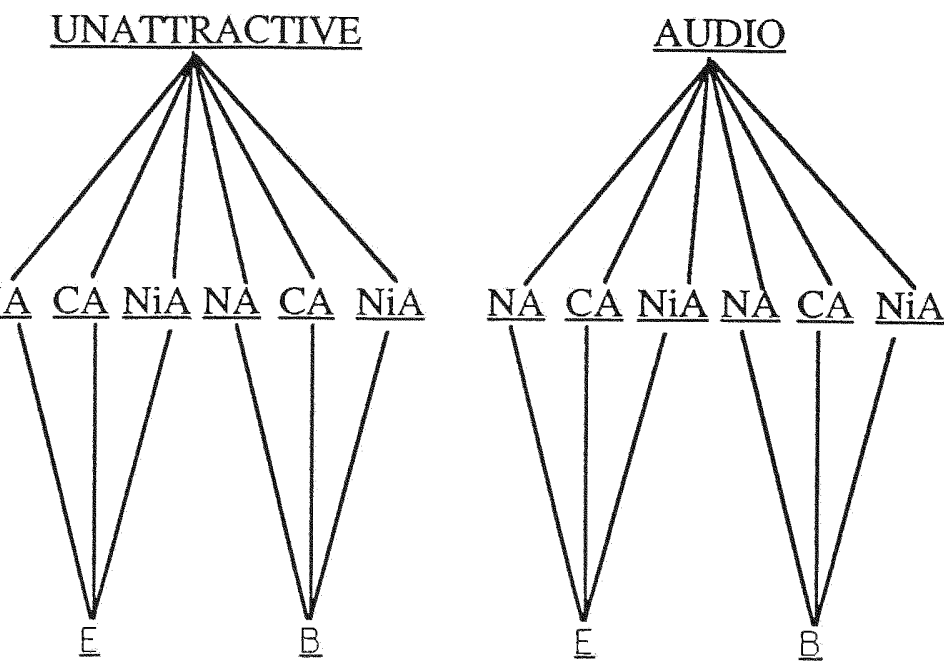

NA CA NiA NA CA NiA

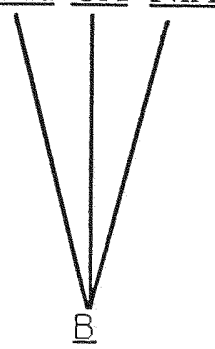

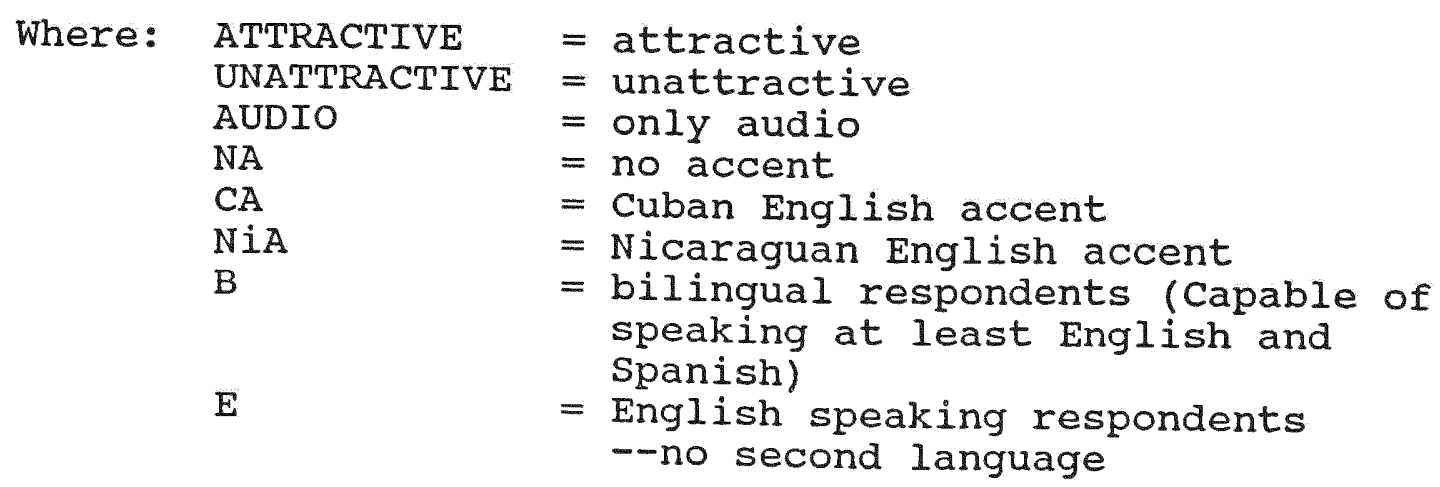


VII. Data collection Procedures

The only instrument used in the study was the questionnaire for respondents' evaluation of the spokesperson. The sales pitch is discussed below.

\section{Sales Pitch}

The sales pitch focused on automobile insurance. This service was chosen because both students and non-students use it. Also, automobile insurance was viewed as a low or high involvement service item, depending on the perception of the respondent. As a result, an evaluation of the impact of the involvement moderating variable on respondents' purchase intentions could be made by using only one service item for both high and low involvement. The hypothetical sales pitch was prepared with an American English accent, Cuban English accent, and Nicaraguan English accent. Two Americans, two Cubans, and two Nicaraguans were used to insure authenticity. Each person read the message several times and the most natural rendition was chosen. "Naturalness" was considered in terms of message flow and realistic sales pitch as determined by the experimenter. Attention was paid to the speed of the presentation, with each of the six recordings lasting approximately 55 seconds. 


\section{AUTOMOBILE INSURANCE SALES PITCH}

You know, I am glad I started working for this particular car insurance company. The car insurance business today is so complicated and has so many types of coverage available, that the client can easily become confused. However, at this company we can cut through the clutter and provide people with personalized service, help them identify their insurance needs, and provide them with the best policy at a very competitive price.

Our claims department is very efficient and all claims are processed in a speedy and professional manner.

Furthermore, this company has been in business since 1949 and with the way that we do business we will be here for many more years. I am so glad I work for this company.

The experiment was conducted by using three different attractive persons, two different unattractive persons, one audio-only presentation, two different American accents, two different Cuban English accents, and two different Nicaraguan English accents were used to produce 36 commercials ( 6 levels of attractiveness $x 6$ levels of accents $=36$ ). To minimize the variation for the physical attractiveness dimension, two individuals--attractive and unattractive--were used as spokespersons for each level of accent. The same three accents--American English, Cuban English, and Nicaraguan English accents--were portrayed by using voice-overs for the spokespersons. This procedure was feasible because the commercials showed the spokesperson sitting at a desk thinking about the sales pitch he would make to potential customers. The spokesperson was not moving his lips; rather, his thoughts 
were "heard" by the audience. This approach eliminated any variation in the audience evaluation caused by changes in voice quality.

Student respondents viewed the video tapes or listened to the audio tapes in a classroom setting. Nonstudents viewed six tapes at the Hollywood Mall in Hollywood, Florida. Each of the non-students viewed, only, the videotapes for one of these 6 possible experimental cells. Also, 30 groups of students viewed the video or audio tapes for the remaining 30 possible experimental cells. The students and non-students were told that they would view or hear a spokesperson presenting a message and that they would be asked to give their impressions of the spokesperson.

students and nonstudents were included in the study to make the sample more representative, but not to investigate the potential differences between students and nonstudent respondents. As a result, an analysis of the student versus nonstudent population was not performed.

\section{Sample}

The sample for the study consisted of 1,162 students and nonstudents of whom 560 (48.2\%) were males and 597 (51.4\%) were females. Tables 5-9 through 5-20 present profiles in these areas: sex, age, education, income, language, ethnicity, parents' native language, language spoken with parents, birthplace of parents and respondents, and U.S. residency. 
TABLE $-5-9$

RESEARCH SAMPLE -- SEX

MALES

FEMALES

NOT SPECIFIED

TOTAL

$\begin{array}{rr}560 & (48.2 \%) \\ 597 & (51.4 \%) \\ 5 & (0.3 \%) \\ 1,162 & (100.0 \%)\end{array}$

TABLE $-5-10$

RESEARCH SAMPLE - AGE

AGE RANGE

18 TO 24

25 TO 29

30 TO 44

45 TO 54

55 TO 64

OVER 65

NOT SPECIFIED

TOTAL
NUMBER

$\begin{aligned} 687 & (59.1 \%) \\ 222 & (19.1 \%) \\ 162 & (13.9 \%) \\ 58 & (5.0 \%) \\ 22 & (1.9 \%) \\ 6 & (0.5 \%) \\ 5 & (0.4 \%) \\ 1,162 & (100.0 \%)\end{aligned}$




\section{TABLE $-5-11$ \\ RESEARCH SAMPLE -- EDUCATION}

EDUCATIONAL LEVEL

HIGH SCHOOL--LESS THAN OR EQUAL

TECHNICAL SCHOOL COMPLETION

ONE TO THREE YEARS OF COLLEGE

COLLEGE GRADUATES

GRADUATE SCHOOL--ATTENDED OR COMPLETE NOT SPECIFIED

TOTAL
NUMBER

$$
\begin{array}{r}
86(7.4 \%) \\
17(1.5 \%) \\
853(73.4 \%) \\
137(11.8 \%) \\
54(4.6 \%) \\
15(1.2 \%) \\
1,162(100.0 \%)
\end{array}
$$

\section{TABLE - 5-12 \\ RESEARCH SAMPLE -- OCCUPATIONAL PROFILE}

POSITION

PROFESSIONAL/MANAGERIAL/TECHNICAL/SALES 565

FARMING/FORESTRY/FISHING/CRAFT \& REPAIR 36 STUDENTS

MISCELLANEOUS

NOT SPECIFIED

TOTAL

NUMBER

$$
\begin{array}{rr}
565 & (48.6 \%) \\
36 & (3.1 \%) \\
460 & (39.6 \%) \\
72 & (6.3 \%) \\
29 & (2.5 \%) \\
1,162 & (100.0 \%)
\end{array}
$$$$
29 \text { (2.5\%) }
$$ 


\section{TABLE $-5-13$ \\ RESEARCH SAMPLE -- INCOME PROFILE}

INCOME RANGE (HOUSEHOLD)

LESS THAN $\$ 10,000 /$ YEAR

$\$ 10,000$ TO $\$ 29,999 /$ YEAR

$\$ 30,000$ TO $\$ 49,999 /$ YEAR

$\$ 50,000$ TO $\$ 99,999 /$ YEAR

OVER $\$ 100,000 /$ YEAR

NOT SPECIFIED

TOTAL
NUMBER

$\begin{aligned} 161 & (13.9 \%) \\ 339 & (29.1 \%) \\ 309 & (26.6 \%) \\ 239 & (20.6 \%) \\ 72 & (6.2 \%) \\ 42 & (3.6 \%) \\ 1,162 & (100.0 \%)\end{aligned}$

TABLE $-5-14$

RESEARCH SAMPLE -- RESPONDENT'S LANGUAGE

NATIVE LANGUAGE(S)

ENGLISH

SPANISH

ENGLISH/SPANISH

FRENCH/CREOLE

ASIAN LANGUAGES

MISCELLANEOUS LANGUAGES

NOT SPECIFIED

TOTAL
NUMBER

$\begin{array}{rr}714 & (61.4 \%) \\ 350 & (30.1 \%) \\ 5 & (0.4 \%) \\ 26 & (2.2 \%) \\ 29 & (2.5 \%) \\ 36 & (3.1 \%) \\ 2 & (0.2 \%) \\ 1,162 & (100.0 \%)\end{array}$




\section{TABLE $-5-15$}

\section{RESEARCH SAMPLE - - RESPONDENT'S ETHNIC PROFILE}

ETHNIC GROUP

AMERICANS (CAUCASIAN)

AFRICAN AMERICAN

CUBANS

HAITIAN

OTHER HISPANIC (E.G., NICARAGUAN)

EUROPEAN

WEST INDIAN

ASIAN

OTHER

NOT SPECIFIED

TOTAL
NUMBER

$$
\begin{aligned}
& 363 \text { (31.3\%) } \\
& 107 \text { (9.2\%) } \\
& 285 \text { (24.5\%) } \\
& 20(1.7 \%) \\
& 228 \text { (19.6\%) } \\
& 13(1.1 \%) \\
& 26(2.2 \%) \\
& 49(4.2 \%) \\
& 48 \text { ( } 4.1 \%) \\
& 23(2.0 \%) \\
& 1,162 \text { (100.0\%) }
\end{aligned}
$$

RESPONDENT'S PARENTS NATIVE LANGUAGE

PARENT

English

Mother

Father

Total
NATIVE LANGUAGE

$\begin{array}{lllll}491(42 \%) & 524 & (45 \%) & 1,015 & (87 \%) \\ 496(43 \%) & 496(43 \%) & 992 & (86 \%) \\ 987(43 \%) & 1,020(44 \%) & \end{array}$




$$
\text { YABLE }=-5-17
$$

\title{
LANGUAGE RESPONDENTS SPEAR WITH PARENTS
}

PARENT

\author{
NATIVE LANGUAGE
}

English Spanish English/Spanish Total

Mother 540 (47\%) $343(30 \%) \quad 135$ (12\%) 1,018 (89\%) Father $531(46 \%) \quad 333(29 \%) \quad 118(10 \%) \quad 982$ (85\%) Total 1,071 (93\%) $676(59 \%) \quad 253(22 \%)$

TABLE - 5-18

BIRTH PLACE OF RESPONDENTS

COUNTRY

UNITED STATES OF AMERICA

CUBA

NICARAGUA

OTHER CENTRAL \& SOUTH AMERICAN COUNTRIES

HAITI

WEST INDIES

ASIA

EUROPE

OTHER

NOT SPECIFIED

TOTAL
NUMBERS

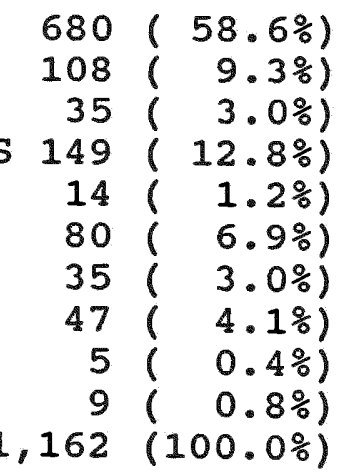




\section{TABLE $-5-19$ \\ RESIDENTS OF U.S.A}

U.S.A (DATE OF RESIDENCY IN U.S.A.)

NUMBERS

BORN IN THE U.S.A

BEFORE 1959

1959 TO 1969

1970 TO 1979

1980 TO 1991

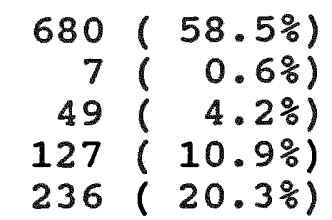

NOT RESIDENTS OF U.S.A.

$63(5.4 \%)$

TOTAL

$1,162(100.0 \%)$

\section{TABLE - 5-20 \\ BIRTH PLACE OF PARENTS}

COUNTRY OF BIRTH

UNITED STATES OF AMERICAN

CUBA

NICARAGUA

CENTRAL AND SOUTH AMERICA

HAITI

WEST INDIES

ASIA

EUROPE

OTHER

NOT SPECIFIED
MOTHER

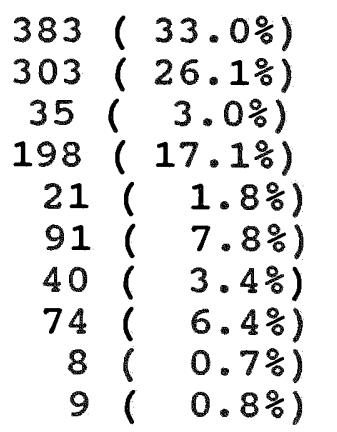

FATHER

392 (33.8\%)

301 (25.9\%)

35 ( $3.0 \%)$

182 (15.7\%)

21 (1.8\%)

$89 \quad(7.7 \%)$

$43 \quad(3.7 \%)$

$80 \quad(6.9 \%)$

$7(0.6 \%)$

$12(1.0 \%)$

TOTAL $1,162(100.0 \%) \quad 1,162(100.0 \%)$

There were 36 cells with a cell count that ranged from a low of 15 to a high of 56 respondents. The matrix below 
depicts the cell count and breakdown. The largest cell contained 56 subjects and 11 cells contained less than 25 subjects.

\section{TABLE - - 5-21 \\ RESPONDENT CELI COUNT BREAKDOWN}

ATTR 1 ATTR 2 ATTR 3 UNATTR 1 UNATTR 2 AUDIO TOTAL

\begin{tabular}{|c|c|c|c|c|c|c|c|c|}
\hline $\begin{array}{l}\text { AMER } \\
\text { AMER }\end{array}$ & $\begin{array}{l}A C 1 \\
A C 2\end{array}$ & $\begin{array}{l}56 \\
34\end{array}$ & $\begin{array}{l}18 \\
26\end{array}$ & $\begin{array}{r}30 \\
-36\end{array}$ & $\begin{array}{l}37 \\
32\end{array}$ & $\begin{array}{l}15 \\
32\end{array}$ & $\begin{array}{l}24 \\
46\end{array}$ & $\begin{array}{l}180 \\
206\end{array}$ \\
\hline $\begin{array}{l}\text { NIC } \\
\text { NIC }\end{array}$ & $\begin{array}{l}\mathrm{ACl} 1 \\
\mathrm{AC2}\end{array}$ & $\begin{array}{l}51 \\
44\end{array}$ & $\begin{array}{l}19 \\
19\end{array}$ & $\begin{array}{l}33 \\
41\end{array}$ & $\begin{array}{l}58 \\
22\end{array}$ & $\begin{array}{l}29 \\
15\end{array}$ & $\begin{array}{l}15 \\
28\end{array}$ & $\begin{array}{l}205 \\
169\end{array}$ \\
\hline $\begin{array}{l}\text { CUB } \\
\text { CUB }\end{array}$ & $\begin{array}{l}\mathrm{AC1} 1 \\
\mathrm{AC2}\end{array}$ & $\begin{array}{l}50 \\
49\end{array}$ & $\begin{array}{l}23 \\
28\end{array}$ & $\begin{array}{l}15 \\
35\end{array}$ & $\begin{array}{l}52 \\
44\end{array}$ & $\begin{array}{l}24 \\
26\end{array}$ & $\begin{array}{l}32 \\
24\end{array}$ & $\begin{array}{l}196 \\
206\end{array}$ \\
\hline TOTF & & 284 & 133 & 190 & 245 & 141 & 169 & 1,162 \\
\hline
\end{tabular}

LEGEND

AMER AC1--AMERICAN ACCENT 1 AMER AC2--AMERICAN ACCENT 2 NIC AC1--NICARAGUAN ACCENT 1 NIC AC2-NICARAGUAN ACCENT 2 CUB AC1--CUBAN ACCENT 1 CUB AC2--CUBAN ACCENT 2

ATTR 1--ATTRACTIVE PRESENTER 1 ATTR 2--ATTRACTIVE PRESENTER 2 ATTR 3--ATTRACTIVE PRESENTER 3 UNATTR 1--UNATTRACTIVE PRESENTER 1 UNATTR 2--UNATTRACTIVE PRESENTER 2 AUDIO--AUDIO-ONLY PRESENTATION

\section{Analytical Techniques}

Covariance structure analysis was used to calculate the influence of each dimension of source credibility on intention to purchase. Analysis of variance (ANOVA) was used to test the differences across groups for the moderating variables. ANOVAs were conducted with the SAS package on the VAX mainframe computer. A LISREL model was used to specify the relationships (Joreskog, 1971; McGraw and Joreskog, 1971; Sorbrom, 1974)

LISREL and ANALYSIS OF VARIANCE for Moderator Variables

In order to calculate the influence of each of the main effects of source credibility on intention to purchase, 
covariance structure analysis was used. Joreskog and Sorbom (1989) LISREL 7.2, PC Version from Scientific Software, was used to calculate the impact of each of these relationships and to assess the concomitant variation and the temporal ordering between the constructs. Ohanian (1991) used the LISREL methodology for her study of the impact of celebrity spokespersons' perceived image on consumers' intention to purchase. She considered the procedure more powerful than traditional methods, since it could account for measurement errors and intercorrelations while simultaneously measuring the effects on the dependent variables.

Joreskog and Sorbom (1988) recommend the following notation to the specify the LISREL model:

$$
\eta=\Gamma \xi+\zeta
$$

where:

$\eta \quad$ is a $(1 \times 1)$ column vector of intention to purchase construct derived from the dependent variables (consider, inquire about, and actually purchase)

$\Gamma \quad$ is a $(1 \times 3)$ coefficient matrix relating the independent constructs (trustworthiness, expertise, and attractiveness) to the intention-topurchase construct

$\xi \quad$ is a ( $3 \times 1)$ column vector of source-credibility constructs derived from the independent variable $(\mathrm{x})$, and

$\zeta$ is a $\left(\begin{array}{lll}1 & x & 1\end{array}\right)$ column vector of the error in the structural equations

FIGURE 5-2 represents the illustration of the recursive LISREL model for the dissertation, where four independent 
variables specify the attractiveness constructs, three independent variables specify the trustworthiness construct, five independent variables specify the expertise construct, and three variables specify the purchase intention construct. The interaction of the moderating variables (involvement, accent, and audience composition) with source credibility variables (attractiveness, trustworthiness, and expertise) is represented by a series of ANOVAs: two levels for involvement, three levels for accent, and two levels for composition of the audience; and the dependent variable purchase intentions. Table 5-22 provides a summary of the measures used in the LISREL model.

To test the model for the impact of the moderator variables, a series of ANOVAs were used for each level of the moderator. This procedure evaluates equality across groups.

For the direct impact of spokesperson characteristics on purchase intentions, a positive and statistically significant relationship for gammas 1,2 and 3 paths will support hypotheses $\mathrm{H} 1, \mathrm{H} 2$, and $\mathrm{H} 3$ respectively. on the other hand, the nature of the impact or interaction of the spokesperson characteristics and the moderating variables on purchase intentions is contingent upon the level of the moderating variables (Kenny and Judd, 1984):

4) if the interaction term (involvement*attractiveness) is statistically significant then $\mathrm{H}(0) 4$ can be rejected.

5) if the interaction term (involvement*trustworthiness) is statistically significant then $\mathrm{H}(0) 5$ can be rejected. 
6) if the interaction term (involvement*expertise) is statistically significant then $\mathrm{H}(0) 6$ can be rejected.

7) if the interaction term (accent*attractiveness) is statistically significant then $\mathrm{H}(0) 7$ can be rejected.

8) if the interaction term (accent*trustworthiness) is statistically significant then $\mathrm{H}(0) 8$ can be rejected.

9) if the interaction term (accent*expertise) is statistically significant then $\mathrm{H}(0) 9$ can be rejected.

10a) if the interaction term of (audience*accent*attractiveness) is statistically significant then $\mathrm{H}(0) 10 \mathrm{~A}$ can be rejected.

10b) if the interaction term (audience*accent) is statistically significant then $\mathrm{H}(0) 10 \mathrm{~B}$ can be rejected:

10c) if the interaction term (audience*attractiveness) is statistically significant then $\mathrm{H}(0) 10 \mathrm{C}$ can be rejected.

10d) if there is a statistically significant difference in the purchase intentions between an English and bilingual speaking audience then $H(0) 10 D$ can be rejected.

11a) if the interaction term (audience*accent*trustworthiness) is statistically significant then $11(0) \mathrm{HA}$ can be rejected.

11b) if the interaction term (audience*trustworthiness) is statistically significant then $\mathrm{H}(0) 11 \mathrm{~B}$ can be 2 rejected.

12a) if the interaction term (audience*expertise*accent) is statistically significant then $H(0) 12 \mathrm{~A}$ can be rejected.

12b) if the interaction term (audience*expertise) is statistically significant then $12(0)$ B can be rejected. 


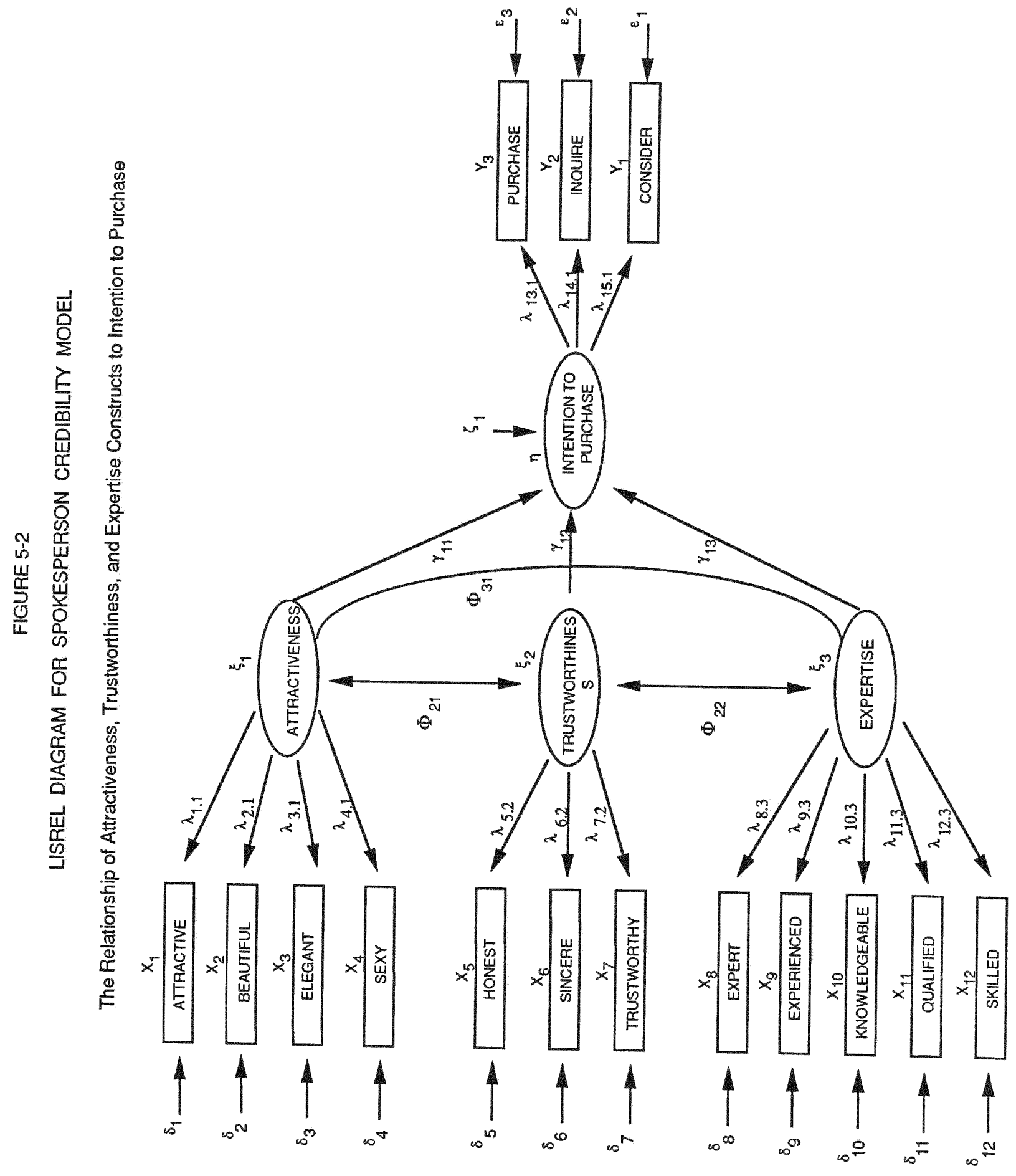


Constructs/Variables Spokesperson Constructs and Variables

Attractiveness

-attractive

-beautiful

-Elegant

- Sexy

Trustworthiness

-honest

-sincere

-trustworthy

Expertise

-expert

-experience

-knowledgeable

-qualified

-skilled

Purchase Intentions

-purchase

- consider

-inquire

Moderating Variables

Involvement

-high $>=6.0$

-low $<=4.4$

Accent

-no accent

- Cuban English Accent

- Nicaraguan English

Accent.

Audience Composition

-English speaking

-Bilingual
Measurement (Questionnaire Items) Taken from Ohanian (1991)

-X1 (seven-point semantic scale)

$-\mathrm{X} 2$ (seven-point semantic Scale)

-X3 (seven-point semantic Scale)

-X4 (seven-point semantic scale)

-x5 (seven-point semantic scale)

-X6 (seven-point semantic scale)

$-x 7$ (seven-point semantic scale)

-x8 (seven-point semantic scale)

-x9 (seven-point semantic Scale)

-X10 (seven-point semantic scale)

-x11 (seven-point semantic scale)

-x12 (seven-point semantic Scale)

-X13 (seven-point semantic scale)

-X14 (seven-point semantic Scale)

-X15 (seven-point semantic Scale)

Taken from Tsalikis, Deshields, and LaTour (1991)

Taken from Zaichkowshy (1985)

-classification based on 20 items

(seven-point semantic scale)

-classification based on presenters' accent grouping

-classification based on questions in the respondent's background information section 


\section{Table 5-22 continued (SUMMARY OF MEASURES IN ANOVA)}

Interaction terms (moderating variables by source credibility constructs)

High/Low Involvement by Attractiveness High/Low Involvement by Trustworthiness High/Low Involvement by Expertise

No Accent/Cuban/Nicaraguan by Attractiveness No Accent/Cuban/Nicaraguan by Trustworthiness No Accent/Cuban/Nicaraguan by Expertise

English/Bilingual Audience by Attractiveness English/Bilingual Audience by Trustworthiness English/Bilingual Audience by Expertise
Measurement of Interaction items

Dummy variables for each level of the moderator (i.e., high product involvement $>=6$, low involvement $<=4.4$ and each of the main effects (i.e., high attractiveness $>=4$, low attractiveness $<=1.8$; high trustworthiness $>=5$, low trustworthiness $<=3$; high expertise $>=4$, low expertise $<=2$ ) and tested for equality across groups.

Dummy variables for each level of the moderator were computed (i.e., American English, Cuban English, and Nicaraguan English) and tested for equality across groups.

Dummy variables for each level of the moderator were computed (i.e., English speaking or Bilingual audience) and tested for equality across groups. 
The issue of identification is important for the determination of a unique solution in covariance structure analysis. There are a number of necessary conditions for identification. If all these conditions are met, there is good possibility that the model is identified. A sufficient condition to identify a one factor model is to have at least three indicators with non-zero loadings and theta delta to be diagonal (Bollen, 1989). The measurement model has endogenous variables (lambda $Y$, theta epsilon--diagonal, phi, eta) with three indicators for eta (i.e., purchase intentions) and the exogenous variables (lambda $x, p h i$, theta delta) with at least three indicators for each of the latent constructs (attractiveness, trustworthiness, and expertise). The model for this study has four factors and is overidentified with more equations (120) than parameters (36). The model has 84 degrees of freedom $(120-36=84)$. Model identification is also evidenced by the fact that the structural model--the gamma matrix--is a regression model between factors with a phi matrix that is full rank. None of the variances is zero and the phi factors are not correlated near one. Additionally, a test of identification at the solution of the LISREL Program indicated that the model was identified.

X. Summary

The research methodology section focused on the details of the study. The study used a $3 \times 3 \times 2$ factorial design to generate the data to test the hypotheses. The sample population was derived from students and local residents in 
the Miami, Florida area. Thirty-six commercials provided the stimulus for the respondents. The questionnaire provided the data that indicated respondents' reactions to each spokesperson. Based on the results of the reliability analysis, the scales were purified by eliminating three variables from the instrument.

Covariance structure analysis was used to analyze the hypothesized relationships in $\mathrm{H} 1, \mathrm{H} 2$, and $\mathrm{H} 3$. A series of ANOVAs were used to evaluate the impact of the moderator variables on the source credibility constructs. The next section, Chapter VI, focuses on the research findings of the study. 


\section{CHAPTER VI. RESEARCH FINDINGS}

This chapter presents the analyses and findings of the investigation. The chapter is organized into two main sections: spokesperson credibility model and hypotheses; and summary of the findings. The first section contains the data screening procedure, confirmatory factor analysis, model fit and parameter estimates, and analysis of variance of moderator variables for the total sample and the various subsamples. The next section contains a summary of the major findings of this study.

\section{THE SPOKESPERSON CREDIBILITY MODEL AND HYPOTHESES}

Fifteen indicator variables were used to generate the four latent constructs in the spokesperson credibility model (see Table 5-7). Also, Table 5-7 shows that these indicator variables and constructs for the spokesperson credibility model were at an appropriate level.

An analysis of the data indicated that the distribution was not multivariate normal. That is, the relative multivariate kurtosis was 1.3 as opposed to 0 for a multivariate normal distribution (Mardia, 1970). As a result, the weighted least squares (WLS) procedure was used to estimate the model's ability to describe the data. The WLS estimating procedure is based on a distribution free assumption for the data. In order to estimate the fit of the model using wLS, both the Pearson correlation matrix and the asymptotic covariance matrix had to be used. The asymptotic covariance matrix was used to express the sampling variation 
of the elements in the correlation matrix. The model was estimated by using the inverse of the asymptotic covariance matrix as the weights for the WLS procedure. For example, correlations that were precisely estimated were given a large weight, while correlations with a large sampling variance were given a small weight (Joreskog and Sorbom, 1989).

B. DATA SOREENING PROCEDURE

The data were screened before the various multivariate analysis procedures were executed. The SAS frequencies and univariate programs were used to evaluate the input data for missing data, univariate outliers, normality, and linearity. The statements used in the questionnaire and the number of missing variables are listed below. There were no outliers for the fifteen variables used in the spokesperson credibility model. Consequently, the LISREL computer program was run using a sample size of 1,035 (89\%).

\section{B. CONFIRMATORY FACTOR ANALYSIS}

Confirmatory factor analysis (CFA) was performed on LISREL. A Pearson correlation matrix (Table 6-2) and an asymptotic covariance matrix were generated from the raw data through PRELIS. Table 6-3 provides the wLS estimates and the standard errors. Also, the corresponding $t$-values for the indicator variables were all significant. All the indicator variables were in the predicted direction, loaded on the designated latent variables, and were statistically significant. 


\section{TABLE - 6-1}

INDICATOR VARIABLES IN SpOkesperson CREDIBILITY MODEL

VARIABLE

CREDIBILITY CONSTRUCTS

-Expert

-Honest

-Classy*

-Experience

-Dependable*

-Elegant

-Knowledgeable

-Sincere

-Sexy

-Qualified

-Trustworthy

-Beautiful

-Skilled

-reliable*

-Attractive
MISSING CASES

TOTAL

$$
\begin{array}{r}
26 \\
9 \\
9 \\
2 \\
9 \\
6 \\
6 \\
12 \\
14 \\
4 \\
5 \\
13 \\
2 \\
2 \\
4
\end{array}
$$

103

* NOT INCLUDED IN TOTAL--NOT IN SPOKESPERSON CREDIBILITY MODEL PURCHASE INTENTION CONSTRUCT

-Purchase

- Inquire

- Consider

9

7

8

TOTAL

24 LISREL ANALYSIS DONE WITH $1,162-(103+24)=1,035$
OBSERVATIONS 
INDICATOR VARIABLES--Spokesperson CREDIBILITY MODEL-continued

\section{INVOLVEMENT}

- Important

61

- of concern

21

- relevant

23

-means a lot

-useful

-valuable

- fundamental

- beneficial

-matters to me

19

-interested

-significant

-vital

- interesting

-exciting

- appealing

- fascinating

-essential

- desirable

- wanted

- needed

SPEAKER'S VOICE் CHARÅCTERISTICS

-Intonation

- Speed

-Accent

BACKGROUND INFORMATION

-Respondent's Sex

-Respondent's Native Language 2

-Mother's Native Language 7

-Father's Native Language $\quad 17$

-Language Speak with Mother 26

- Language Speak with Father 61

-Language Speak with Children 0

-Language Speak with Co-Workers 82

-Respondent Mother's Birth Place 9

-Respondent Father's Birth Place 12

-Respondent's Birth Place 12

-Residence in U.S.A.

-Respondent's Ethnic Group 23

-Respondent's Age 5

-Respondent's Education 15

-Respondent's Occupation $\quad 29$

-Respondent's Household Income 42 
The overall fit for the CFA model for the spokesperson credibility data was considered excellent. The GOODNESS OF FIT INDEX (GFI) and the ADJUSTED GOODNESS OF FIT INDEX (AGFI) were very high--.995 and .993, respectively. A nonsignificant CHI-SQUARE WITH 84 DEGREE OF FREEDOM $=36.42, P$ $=.999$ and a ROOT MEAN SQUARE RESIDUAL (RMR) of .110 give further evidence of the excellent fit between the model and the data (Joreskog and Sorbom, 1989).

\section{MODEL FIT AND PARAMETER ESTIMATES}

All of the relationships proposed for the path between the latent constructs were in the predicted direction. All but one--attractiveness--were statistically significant (trustworthiness $t$-Value $3.0, P<0.003$; and expertise $t$-Value $4.4, \mathrm{P}<0.0001)$. However, even the attractiveness construct was nearly significant with a $t$-value of $1.9, P<0.057$. The overall fit for the LISREL model for the spokesperson credibility data was considered very good. Like the CFA model, the GFI and the AGFI models were very high--.995 and .993, respectively. A non-significant chi square with 84 degrees of freedom $=36.42(\mathrm{P}=1.00)$ and a RMR of .110 give additional evidence of the strong fit between the model and the data. Also, the squared multiple correlation for the structural equation was $48.3 \%$. In other words, the model explained $48.3 \%$ of the variance in the dependent latent construct, purchase intentions. Figure 6-1 provides the WLS estimates, standard errors, estimates, and $t$-values for the model path coefficients. 


\section{TABLE $-6-2$}

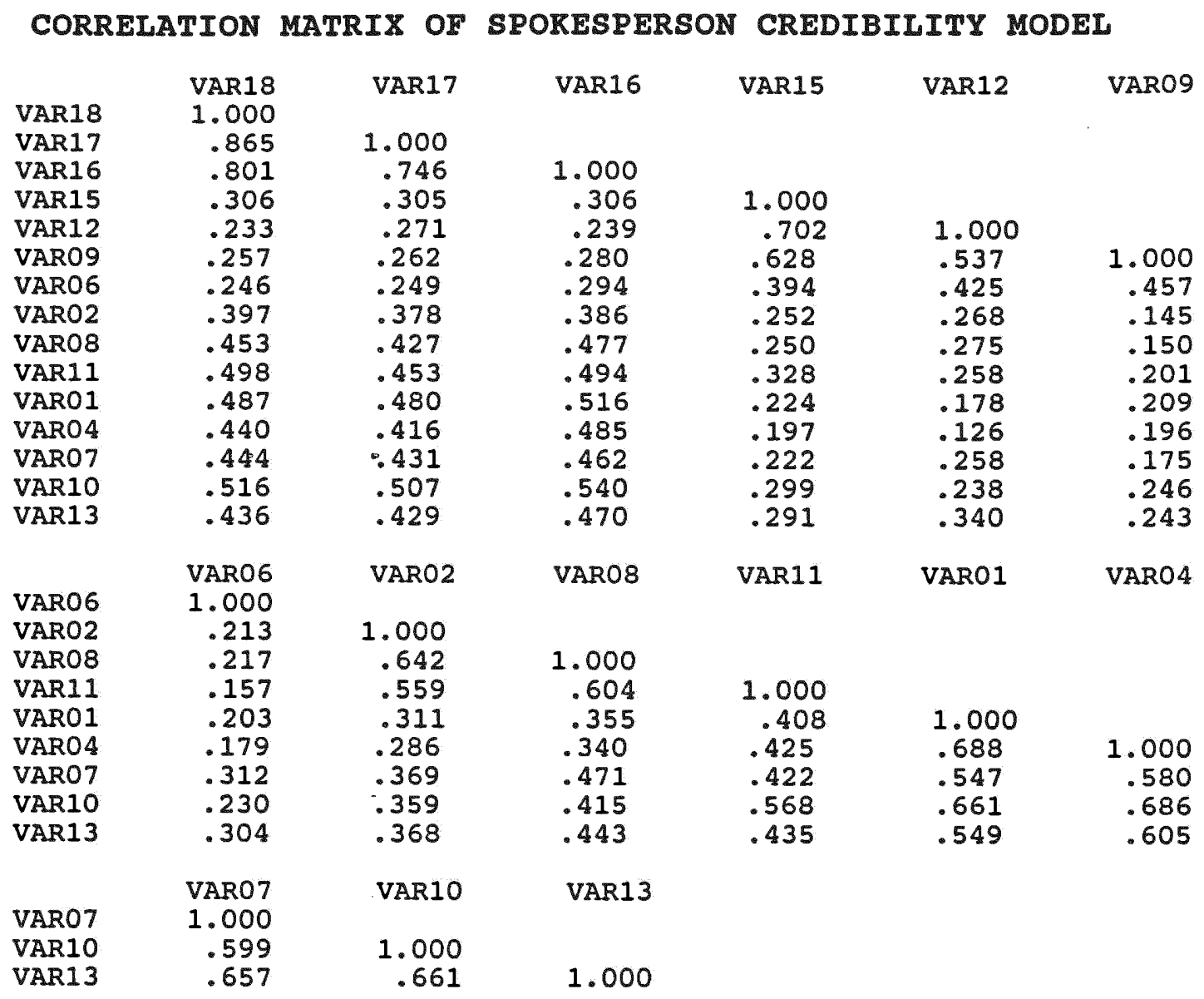

\section{LEGEND}

PURCHASE INTENTIONS

VAR 16 - PURCHASE

VAR 17 - INQUIRE

VAR 18 - CONSIDER

\section{ATTRACTIVENESS}

VAR 15 - ATTRACTIVE

VAR 12 - BEAUTIFUL

VAR 09 - SEXY

VAR 06 - ELEGANT
TRUSTWORTHINESS

VAR 11 - TRUSTWORTHY

VAR 02 - HONEST

VAR 08 - SINCERE

\section{EXPERTISE}

VAR 01 - EXPERT

VAR 04 - EXPERIENCE

VAR 07 - KNOWLEDGEABLE

VAR 10 - QUALIFIED

VAR 13 - SKILLED 
TABLE - $-6-3$

SUMMARY STATISTICS FOR CONFIRMATORY FACTOR ANALYSIS

$\begin{aligned} \text { CHI-SQUARE WITH } 84 \text { DEGREES OF FREEDOM } & =36.42(P=1.000)^{1} \\ \text { GOODNESS OF FIT INDEX } & = \\ \text { ADJUSTED GOODNESS OF FIT INDEX } & = \\ \text { ROOT MEAN SQUARE RESIDUAL } & =.995 \\ \text { RON } & .993\end{aligned}$

LISREL ESTIMATES (WEIGHTED LEAST SQUARES)

ATTRACTIVENESS TRUSTWORTHINESS EXPERTISE PURCHASE

\begin{tabular}{lcccc} 
ATTRACTIVE & .878 & .000 & .000 & .000 \\
BEAUTIFUL & .716 & .000 & .000 & .000 \\
SEXY & .648 & .000 & .000 & .000 \\
ELEGANT & .407 & .000 & .000 & .000 \\
\hline HONEST & .000 & .636 & .000 & .000 \\
SINCERE & .000 & .673 & .000 & .000 \\
TRUSTWORTHY & .000 & .709 & .000 & .000 \\
\hline EXPERTISE & .000 & .000 & .781 & .000 \\
EXPERIENCE & .000 & .000 & .812 & .000 \\
KNOWLEDGEABLE & .000 & .000 & .571 & .000 \\
QUALIFIED & .000 & .000 & .728 & .000 \\
SKILLED & .000 & .000 & .000 \\
\hline & & & & .000 \\
PURCHASE & .000 & .000 & .000 & .724 \\
INQUIRE & .000 & .000 & .000 & .940 \\
CONSIDER & .000 & .000 & .000 & .978
\end{tabular}

Hypotheses one, two, and three, respectively predicting the impact of attractiveness, trustworthiness, expertise on purchase intention were evaluated by Hierarchical Model Testing. The procedure is used to assess the significance of a latent construct in a model by restricting (i.e, fixing) its path and comparing the results with a model that has an unrestricted path. The impact of the latent construct is determined by taking the difference in the chi squares between

${ }^{1}$ A statistically non-significant CHI-SQUARE means that the proposed relationships between the constructs and variables are explained by the way they are depicted in the model. 
the two models and assessing the statistical significance of the CHI-SQUARE with one degree of freedom. In H1, the CHISQUARE for the model when the attractiveness construct was restricted on purchase intention was 39.53 (FIGURE 6-2). Taking the difference between the CHI-SQUARES for the restricted and the unrestricted model gave a CHI-SQUARE of $3.11(39.53-36.42=3.11)$. A CHI-SQUARE of 3.11 with one degree of freedom is significant at the 0.08 percent level. For H2, the CHI-SQUARE for the model when the trustworthiness construct was restricted on purchase intention was 43.63 (FIGURE 6-3). Taking the difference between the CHI-SQUARES for the restricted and the unrestricted model gave a CHISQUARE of 7.21 , which is significant at the 0.007 level with one degree of freedom. In $\mathrm{H} 3$, the CHI-SQUARE for the model when the expertise construct was restricted on purchase intention was 51.58 (FIGURE 6-4). Taking the difference between the CHI-SQUARES for the restricted and the unrestricted model gave a CHI-SQUARE of 15.16, which is significant at the 0.0001 level with one degree of freedom. Thus, $\mathrm{H} 1$ was supported at the 0.08 level, while $\mathrm{H} 2$ and $\mathrm{H} 3$ were supported at the 0.007 and 0.0001 level respectively.

\section{ANALYSIS OF VARIANCE FOR MODERATOR VARIABLES}

A series of ANOVAs were performed to test the remaining hypotheses. All ANOVAs were performed on SAS with GLM and the SS3 option to compute the means. The modifying variables in this study were involvement, spokesperson accent, and the speaking composition of the audience (bilingual vs English- 
only). Each of the subsamples was formed by taking high and low estimates of a moderator variable; for example, high and low involvement, trustworthiness, and expertise; and discrete parts of the moderator variable; for example, American accent, Nicaraguan accent, Cuban accent, English speaking audience and bilingual audience.

Hypothesis $\mathrm{H}(0) 4$ evaluates the impact of the interaction of the involvement moderating variable and the spokesperson's attractiveness construct on purchase intentions. The results of the ANOVA indicate that the interaction term of attractiveness and involvement ( $F$ Value $0.49, P<0.49$ ) is not statistically significant. The main effect of spokesperson's attractive ( $F$ Value 57.85, $P<0.0001$ ) is statistically significant, however the involvement moderating variable is not statistically significant (Table 6-4).

The interaction terms for involvement and audio-only presentation ( $F$ Value $0.04, \mathrm{P}<0.53$ ) shown in Table 6-5 is not statistically significant. Also, the involvement moderating variable and the audio-only presentation variable ( $F$ Value 2.74, $\mathrm{P}<0.10 ; \mathrm{F}$ Value $0.07, \mathrm{P}<0.79$ respectively) are not statistically significant for the audio-only presentation media. Consequently, $\mathrm{H}(0) 4$ is not rejected.

$\mathrm{H}(0) 5$ evaluates the impact of the interaction of the low involvement moderating variable and spokesperson's trustworthiness on purchase intentions. 


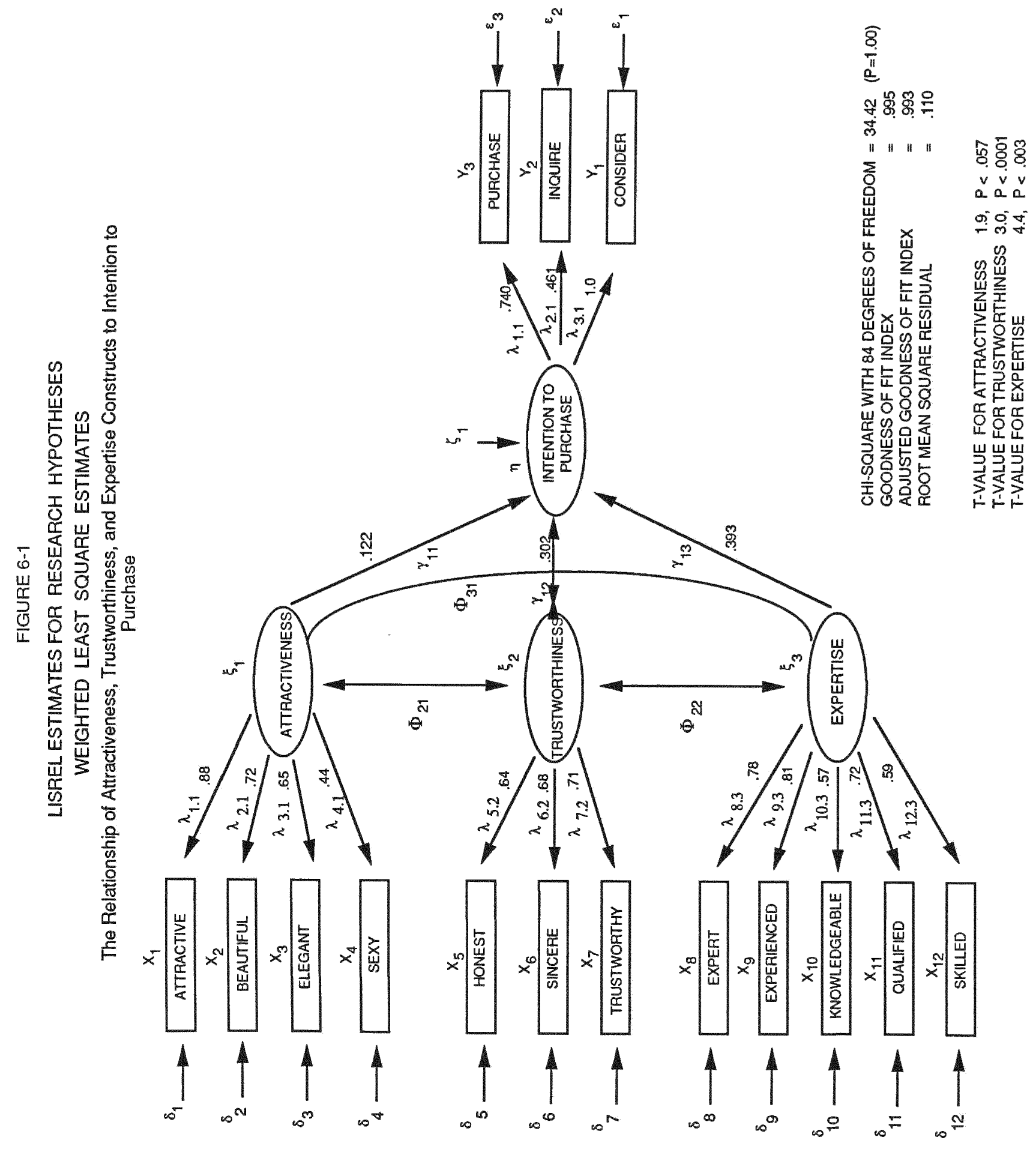




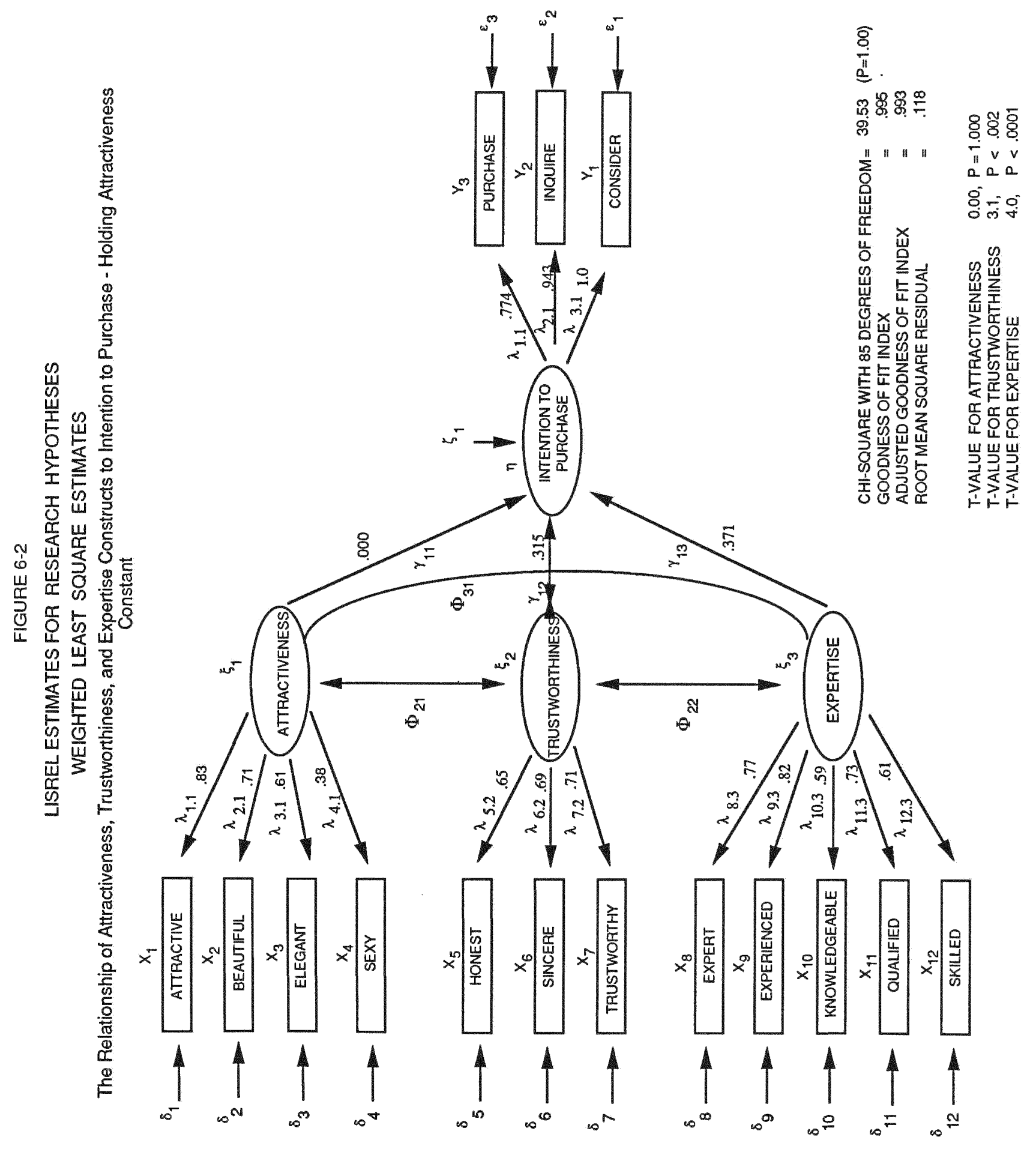




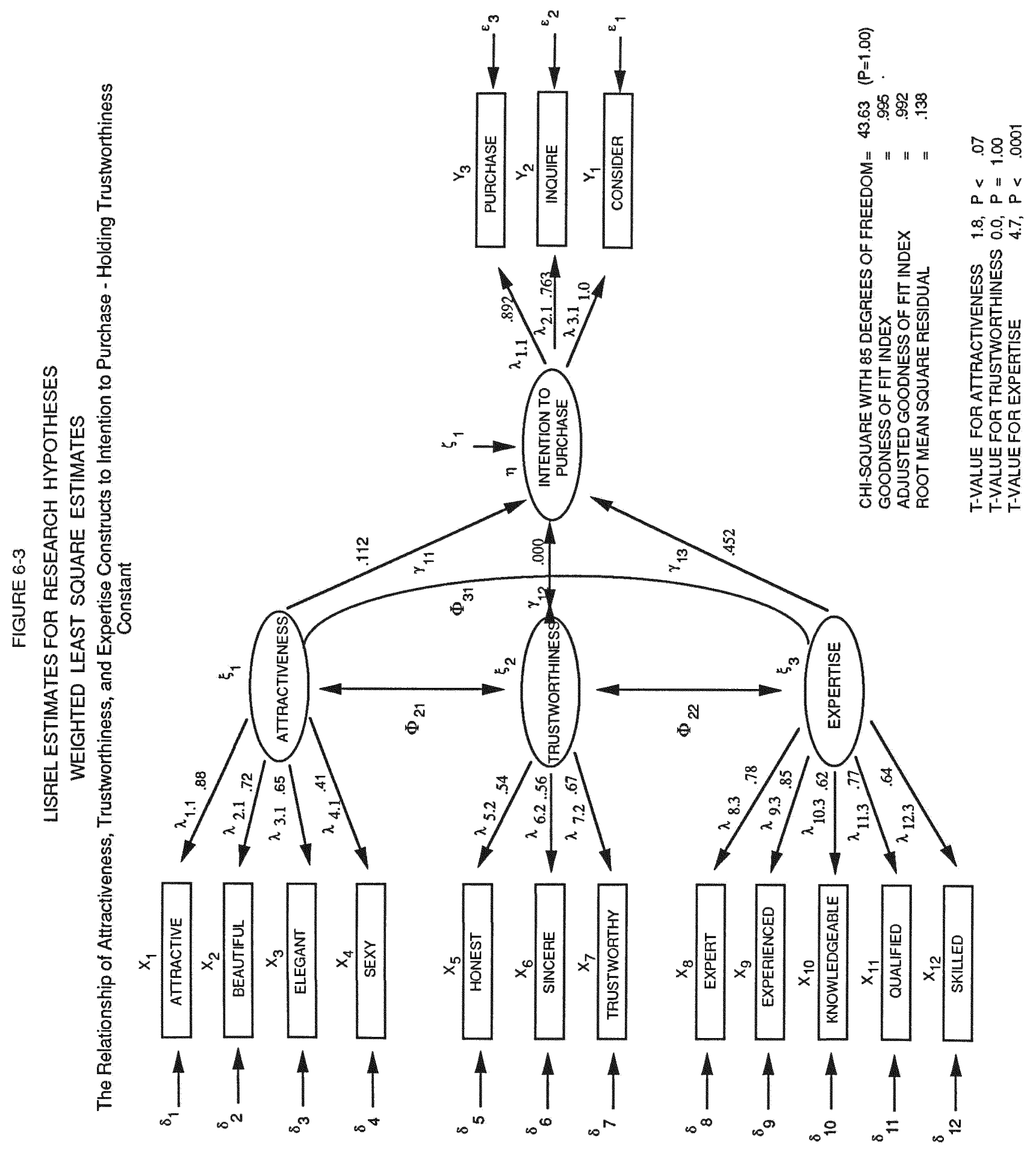




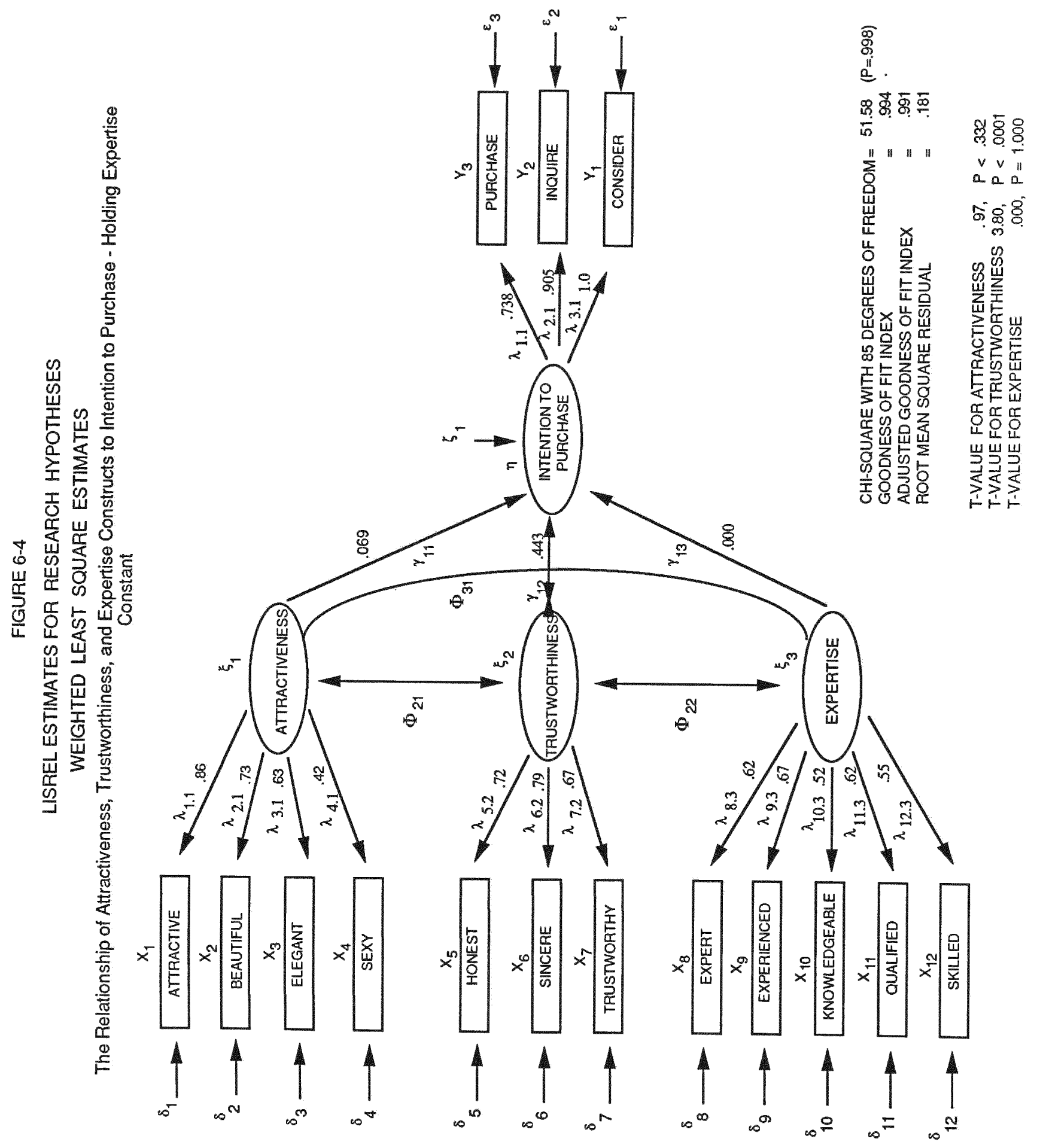




$$
\text { TABLE - } 6-4
$$

ANALYSIS OF VARIANCE FOR

INVOLVEMENT AND ATTRACTIVENESS OF THE SPOKESPERSON

Source D.F. Type IIISS Mean squares F/P-VALUE

$\begin{array}{lrrrr}\text { Attract } & 1 & 176.85 & 176.85 & 57.85 / .0001 \\ \text { Involvement } & 1 & 1.66 & 1.66 & 0.54 / .4600 \\ \text { Attract*Invol } & 1 & 1.49 & 1.49 & 0.49 / .4900\end{array}$

R-Square .18 Root MSE 1.749 Purchase Intention Mean 2.65

LEGEND

Attract--ATTRACTIVENESS PRODUCT

InVO1--INVOLVEMENT WITH THE

TABLE $-6-5$

ANALYSIS OF VARIANCE FOR INVOLVEMENT AUDIO-ONLY PRESENTATION OF THE SPOKESPERSON

Source D.F. Type III SS Mean Squares F/P-VALUE

Audio

$1 \quad 0.24$

$1 \quad 9.27$

Invol

Audio*Invol

11.35

0.24

9. 27

$0.07 / .7900$

1.35

$2.74 / .1000$

$0.40 / .5300$

R-Square.007 Root MSE 1.839 Purchase Intention Mean 2.70 LEGEND

Audio--AUDIO-ONLY PRESENTATION OF THE SPOKESPERSON InVOI--INVOLVEMENT WITH THE PRODUCT 
The results of the ANOVA show that the interaction term of spokesperson's trustworthiness and involvement is statistically significant (F-Value 10.54, $\mathrm{P}<0.001$ ). An analysis of the means shows that spokespersons that are perceived as having high trustworthiness have a greater impact on the purchase intentions of consumers who view the product as a high involvement item rather than a low involvement item. Consequently, $\mathrm{H}(0) 5$ is rejected. It should be noted that the main effect of trustworthiness (F-Value 206.96, $\mathrm{P}<0.0001$ ) is statistically significant. However, the involvement moderating variable (F-Value $2.73, \mathrm{P}<0.10$ ) is not statistically significant (Table 6-6). As a result, $\mathrm{H}(0) 5$ is rejected.

$H(0) 6$ evaluates the impact of the interaction between the involvement moderating variable and spokesperson's expertise on purchase intentions. The results of the ANOVA (Table 6-7) indicate that the spokesperson's expertise and involvement interaction term is statistically significant (F-Value 11.90, $P<0.001)$. An analysis of the mean show that spokespersons that are perceived as having high expertise have a greater impact on the purchase intentions of consumers that view the product as a high involvement item rather than a low involvement item. Based on these findings, $\mathrm{H}(0) 6$ is rejected. It should be noted that the main effects of expertise and involvement (F-Value 233.69, $\mathrm{P}<0.0001 ; \mathrm{F}$-Value 10.46, $\mathrm{P}<0.001$ respectively) are statistically significant. 
Hypothesis $\mathrm{H}(0) .7$ assesses the impact of the interaction of spokesperson's attractiveness and the accent moderating variable on purchase intentions.

\author{
TABLE - 6-6 \\ ANALYSIS OF VARIANCE FOR \\ INVOLVEMENT AND TRUSTWORTHINESS OF THE SPOKESPERSON
}

\begin{tabular}{|c|c|c|c|c|}
\hline Source & $\underline{D . F}$. & Type III SS & Mean Squares & F/P-VALUE \\
\hline Trus & 1 & 490.00 & 490.00 & $2,731.1000$ \\
\hline $\begin{array}{l}\text { Invol } \\
\text { Trust* Invol }\end{array}$ & $\begin{array}{l}1 \\
1\end{array}$ & $\begin{array}{r}6.47 \\
24.95\end{array}$ & $\begin{array}{r}6.47 \\
24.95\end{array}$ & $\begin{array}{r}2.73 \% .1000 \\
10.54 \% .0010\end{array}$ \\
\hline Trust*Invol & 1 & 24.95 & 24.95 & $10.54 / .0010$ \\
\hline
\end{tabular}

R-Square .42 Root MSE 1.539 Purchase Intention Mean 2.76

INVOLVEMENT

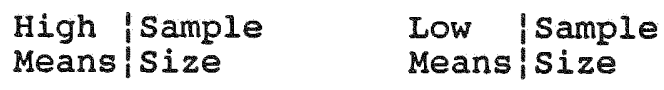

TRUSTWORTHINESS

\begin{tabular}{lll|l|l} 
HIGH & 4.56 & $(90)$ & 3.72 & $(55)$ \\
LOW & 1.54 & $(89)$ & 1.80 & $(110)$
\end{tabular}

LEGEND

Trust--TRUSTWORTHINESS

InVOI--INVOLVEMENT WITH THE PRODUCT

HIGH--HIGH SPOKESPERSON'S TRUSTWORTHINESS

LOW--LOW SPOKESPERSON'S TRUSTWORTHINESS

The results of the. ANOVA (Table 6-8) indicate that the interaction term for spokesperson's attractiveness and accent is statistically significant (F-Value 9.75, $\mathrm{P}<0.002)$. An analysis of the means show that spokespersons that are perceived as attractive with an American English accent have 
a greater impact on the purchase intentions of consumers than attractive spokespersons with a Cuban or Nicaraguan English accent.

\author{
TABLE - 6-7 \\ ANALYSIS OF VARIANCE FOR \\ INVOLVEMENT AND EXPERTISE OF THE SPOKESPERSON
}

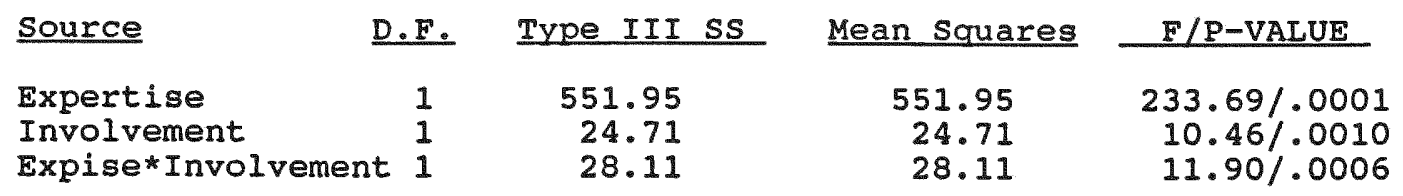

R-Square .44 Root MSE 1.54 Purchase Intention Mean 2.83

INVOLVEMENT

\begin{tabular}{|c|c|}
\hline h & I san \\
\hline
\end{tabular}

EXPERTISE

\begin{tabular}{lll|l|l} 
HIGH & 4.81 & $(76)$ & 3.68 & $(75)$ \\
LOW & 1.63 & $(95)$ & 1.68 & $(85)$
\end{tabular}

LEGEND

Expertise--SPOKESPERSON'S EXPERTISE

Involvement--INVOLVEMENT WITH THE PRODUCT

HIGH--HIGH SPOKESPERSON'S EXPERTISE

LOW--LOW SPOKESPERSON'S EXPERTISE

The main effects of spokesperson's attractiveness and the accent moderating variable (F-Value 134.68, $\mathrm{P}<0.0001 ; \mathrm{F}$-Value 18.17, $\mathrm{P}<0.0001$ respectively), are statistically significant. The interaction term for the audio-only presentation and the spokesperson's accent (F-Value 1.32, $\mathrm{P}<0.25$ ) is not statistically significant (Table 6-9). Also, the main effect of the audio-only presentation of the spokesperson (F-Value $2.41, \mathrm{P}<0.12$ ) is not statistically significant, however, the 
spokesperson's accent moderating variable (F-Value $20.33, \mathrm{P}<$ 0.0001 ) is statistically significant. As a result, $H(0) 7$ is rejected.

\begin{tabular}{|c|c|c|c|c|}
\hline \multirow[b]{2}{*}{ Source } & \multicolumn{4}{|c|}{$\begin{array}{l}\text { ANALYSIS OF VARIANCE FOR } \\
\text { ATIRACTIVENESS OF THE SPOKESPERSON }\end{array}$} \\
\hline & D.F. & Type III SS & Mean Squares & F/P-VALUE \\
\hline $\begin{array}{l}\text { Attractive } \\
\text { Accent } \\
\text { Attractive*Accent }\end{array}$ & $\begin{array}{r}1 \\
-1 \\
-1\end{array}$ & $\begin{array}{r}357.51 \\
48.25 \\
25.87\end{array}$ & $\begin{array}{l}357.51 \\
48.25 \\
25.87\end{array}$ & $\begin{array}{c}134.68 / .0001 \\
18.17 / .0001 \\
9.75 / .0020\end{array}$ \\
\hline R-Square . 26 & oot & SE 1.629 & rchase Intent & n Mean 2.79 \\
\hline
\end{tabular}

ACCENT

Eng. |Sample Means|Size
Span. I Sample Means|size

ATTRACTIVENESS

$\mathrm{HIGH}$

LOW

$4.25 \mid(111)$

$1.95($ (62)

$3.10(182)$

$1.78(165)$

\section{LEGEND}

HIGH--HIGH SPOKESPESON'S ATTRACTIVENESS

LOW--LOW SPOKESPERSON'S ATTRACTIVENESS

Eng.--AMERICAN ENGLISH ACCENT

Span.--CUBAN ENGLISH OR NICARAGUAN ENGLISH ACCENT

TABLE - 6-9

ANALYSIS OF VARIANCE FOR

ACCENT AND AUDIO-ONLY PRESENTATION OF THE SPORESPERSON

$\begin{array}{lccccr}\text { Source } & \text { D.F. } & \text { Type III SS } & \text { Mean Squares } & \text { F/P-VALUE } \\ \text { Audio-Only } & 1 & 7.42 & & 7.42 & 2.41 / .1211 \\ \text { Accent } & 1 & 62.66 & & 62.66 & 20.33 / .0001 \\ \text { Audio-Only*Accent } 1 & 4.06 & & 4.06 & 1.32 / .2500\end{array}$

R-Square .04 Root MSE 1.755 Purchase Intention Mean 2.75 
$H(0) 8$ evaluates the impact of the interaction of spokesperson's trustworthiness and the accent moderating variable on purchase intentions. The results of the ANOVA (Table 6-10) indicate that the interaction term of spokesperson's trustworthiness and accent (F-Value 6.30, $\mathrm{P}<0.010$ is statistically significant. An analysis of the means show that spokespersons that are perceived as trustworthy with an American English accent have a greater impact on the purchase intentions of consumers than trustworthy spokespersons with a Cuban or Nicaraguan English accent. As a result, $\mathrm{H}(0) 8$ is rejected. It should be noted that the main effects of the trustworthiness construct and the accent moderating variable (F-Value $420.42, \mathrm{P}<0.0001 ; \mathrm{F}$-Value $32.61, \mathrm{P}<0.0001$ respectively) are statistically significant.

\section{TABLE -- 6-10 \\ ANALYSIS OF VARIANCE FOR \\ ACCENT AND TRUSTWORTHINESS OF THE SPORESPERSON}

Source D.F. Types III SS Mean Squares F/P-VALUE

$\begin{array}{lrrrr}\text { Trust } & 1 & 921.33 & 921.33 & 420.92 / .0001 \\ \text { Accent } & 1 & 71.46 & 71.46 & 32.61 / .0001 \\ \text { Trust*Accent } & 1 & 13.80 & 13.80 & 6.30 \% .0100\end{array}$

R-Square .43 Root MSE 1.48 Purchase Intention Mean 2.76

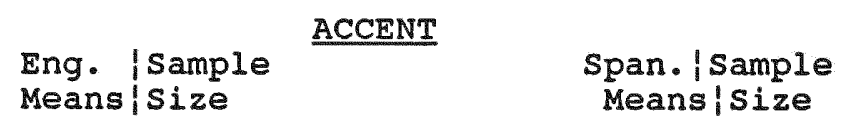

TRUSTWORTHINESS

\begin{tabular}{lll|l} 
HIGH & 4.78 & $(107)$ & $3.77 \mid(184)$ \\
LOW & 1.96 & $(113)$ & 1.56
\end{tabular}

LEGEND

Eng.--AMERICAN ENGLISH ACCENT ACCENT--SPOKESPERSON'S ACCENT Span.--CUBAN ENGLISH OR NICARAGUAN ENGLISH ACCENT

Trust--SPOKESPERSON'S TRUSTWORTHINESS 
$\mathrm{H}(0) 9$ evaluates the impact of the interaction between spokesperson's expertise and the accent moderating variable on purchase intentions. The results of the ANOVA (Table 6-11) indicate that the interaction term of spokesperson's expertise and accent (F-Value $0.55, \mathrm{P}<0.46)$ is not statistically significant. The main effect of expertise (F-Value 383.01, $\mathrm{P}<0.0001$ ) is statistically significant, while the moderating variable of spokesperson's accent (F-Value $2.46, P<0.12$ ) is not statistically significant. Consequently, $\mathrm{H}(0) 9$ is not rejected.

\section{TABLE - 6-11 \\ ANALYSIS OF VARIANCE FOR \\ ACCENT AND EXPERTISE OF THE SPORESPERSON}

\begin{tabular}{|c|c|c|c|c|}
\hline Source & D.F. & Type III SS & Mean Squares & $F / P$-VALUE \\
\hline & $\begin{array}{l}1 \\
1\end{array}$ & $\begin{array}{r}830.92 \\
5.34\end{array}$ & $\begin{array}{r}830.92 \\
5.34\end{array}$ & $\begin{array}{r}383.01 / .0 \\
2.46 \%\end{array}$ \\
\hline ACC & 1 & 1.20 & 1.20 & $0.55 / .4$ \\
\hline
\end{tabular}

R-Square .45 Root MSE 1.47 Purchase Intention Mean 2.84

LEGEND

EXpert--SPOKESPERSON'S EXPERTISE

ACC--SPOKESPERSON'S ACCENT

$\mathrm{H}(0) 10 \mathrm{~A}$ examines the impact of the interaction among spokesperson's attractiveness and accent, and the language speaking capability of the audience on the consumer's purchase intentions. The results of the ANOVA (Table 6-12) indicate that the three-way interaction term spokesperson's 
attractiveness and accent, and language speaking capability of the audience (F-Value 4.66, $\mathrm{P}<0.001$ ) is statistically significant. The ANOVA indicates that the 2 two-way interaction terms are not statistically significant: spokesperson's attractiveness and audience language speaking capability (F-Value $0.11, \mathrm{P}<0.74$ ) and spokesperson's accent and audience language speaking capability (F-Value 1.53, $\mathrm{P}<0.22)$. As a result, $\mathrm{H}(0) 10 \mathrm{~A}$ can be rejected. An analysis of the means show that spokespersons who are perceived as attractiveness and have an American English accent have a greater impact on purchase intentions of English speaking and Bilingual consumers than attractive spokespersons who have a Cuban or Nicaraguan English accent. Since a spokesperson's accent and the speaking capability of the audience is not statistically significant $\mathrm{H}(0) 10 \mathrm{~B}$ can be not rejected. Also, the interaction term spokesperson's attractiveness and the language speaking capability of the audience is not statistically significant. As a result, $\mathrm{H}(0) 10 \mathrm{C}$ is not rejected. Also:, the spokesperson's attractiveness and accent moderating variable (F-Value 131.39, $\mathrm{P}<0.0001 ; \mathrm{F}$-Value 14.80, $\mathrm{P}<0.0001$ respectively) are statistically significant.

The three-way interaction term of the audio presentation, spokesperson's accent, and language speaking capability of the audience (F-Value $0.58, P<0.56$ ) is not statistically significant (Table 6-13). Also, the two-way interaction terms of the audio presentation and audience's language speaking capability (F-Value 1.11, $\mathrm{P}<0.29$ ) and 
spokesperson's accent and audience language speaking capability (F-Value 1.67, $\mathrm{P}<0.20)$ are not statistically significant. The audio presentation (F-Value 1.95, $\mathrm{P}<0.16$ ) is not statistically significant. Also, the moderating variable of the spokesperson's accent (F-Value 23.32, $\mathrm{P}<0.0001)$ is statistically significant. Interesting the audience's language speaking capability (F-Value 7.34, $\mathrm{P}<0.007)$ is statistically significant for the audio presentation but it is not statistically significant for the visual presentation ( $F-$ Value $0.30, \mathrm{P}<0.58$ ). As a result, $H(0) 10 D$ is not rejected when the audience can view the spokesperson, but $H(0) 10 D$ can be rejected when the audience can not view the spokesperson. Consequently, the purchase intentions of English speaking and Bilingual respondent's are different when they are listening to an audio presentation, but they are the same when they can see and hear the spokesperson.

$\mathrm{H}(0) 11 \mathrm{~A}$ assesses the impact of the interaction among spokesperson's trustworthiness, accent and language speaking capability on purchase intentions. The results of the ANOVA (Table 6-14) indicate that the three-way interaction term of spokesperson's trustworthiness, accent, and audience language speaking capability (F-Value of 3.42 and $\mathrm{P}<0.03$ ) is statistically significant. 


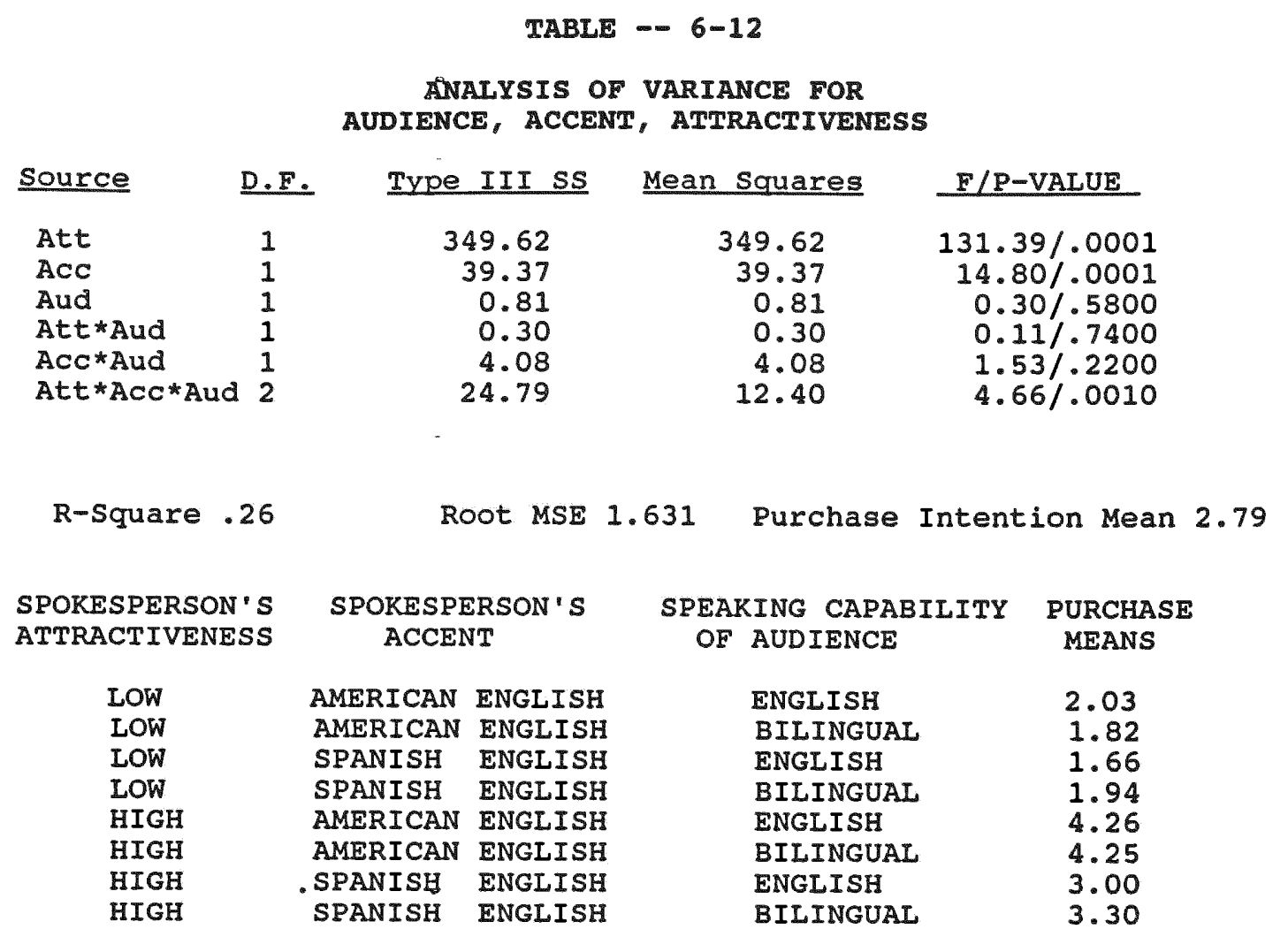

\section{LEGEND}

AT(H) --HIGH SPOKESPERSON'S ATTRACTIVENESS

AT $(L)$--LOW SPOKESPERSON'S ATTRACTIVENESS

A-----SPOKESPERSON'S ACCENT

Audience--LANGUAGE SPEAKING CAPABILITY OF THE RESPONDENTS

An analysis of the means show that spokespersons who are perceived as trustworthy and have an American English accent have a greater impact on purchase intentions of English speaking and Bilingual consumers than trustworthy spokespersons who have a Cuban or Nicaraguan English accent. The 2 two-way interaction terms for: spokesperson's accent and audience language speaking capability $(\mathrm{F}$ - Value $0.01 . \mathrm{P}<0.91$ ) 
spokesperson's trustworthiness and audience language speaking capability (F-Value 1.26, $\mathrm{P}<0.26$ ) are not statistically significant.

TABLE $--6-13$

ANALYSIS OF VARIANCE FOR

AUDIENCE, SPOKESPERSON'S ACCENT AND AUDIO-ONLY PRESENTATION

Source D.F. Type IIISS Mean squares F/P-VALUE

$\begin{array}{lrrrr}\text { Audio } & 1 & 5.99 & 5.99 & 1.95 / .1600 \\ \text { Acc } & 1 & 71.56 & 71.56 & 23.32 / .0001 \\ \text { Aud } & 1 & 22.51 & 22.51 & 7.34 / .0070 \\ \text { Audio*Aud } & 1 & 3.41 & 3.41 & 1.11 / .2900 \\ \text { ACC*Aud } & 1 & 5.12 & 5.12 & 1.67 / .2000 \\ \text { Audio*ACC*Aud } & 2 & 3.54 & 1.77 & 0.58 / .5600\end{array}$

R-Square .05 Root MSE 1.75 Purchase Intention Mean 2.75

\section{LEGEND}

AudiO--AUDIO-ONLY PRESENTATION

ACC--SPOKESPERSON'S ACCENT

Aud--LANGUAGE SPEAKING CAPABILITY OF THE RESPONDENTS

As a result, $\mathrm{H}(0) 11 \mathrm{~A}$ is rejected but $\mathrm{H}(0) 11 \mathrm{~B}$ is not rejected. The main effect of trustworthiness (F-Value 391.95, $P<0.0001)$, the moderating variables of accent (F-Value 30.59 , $\mathrm{P}<0.0001$ ) and the speaking capability of the audience (F-Value $4.25, \mathrm{P}<0.04)$ are statistically significant. $H(0) 12$ evaluates the impact of the interaction among spokesperson's expertise, accent and audience language speaking capability on purchase intentions. The results of the ANOVA (Table 6-15) indicate that the three-way interaction term of spokesperson's expertise, accent, and the speaking 
capability of the audience (F-Value $0.27, \mathrm{P}<0.77$ ) is not statistically significant.

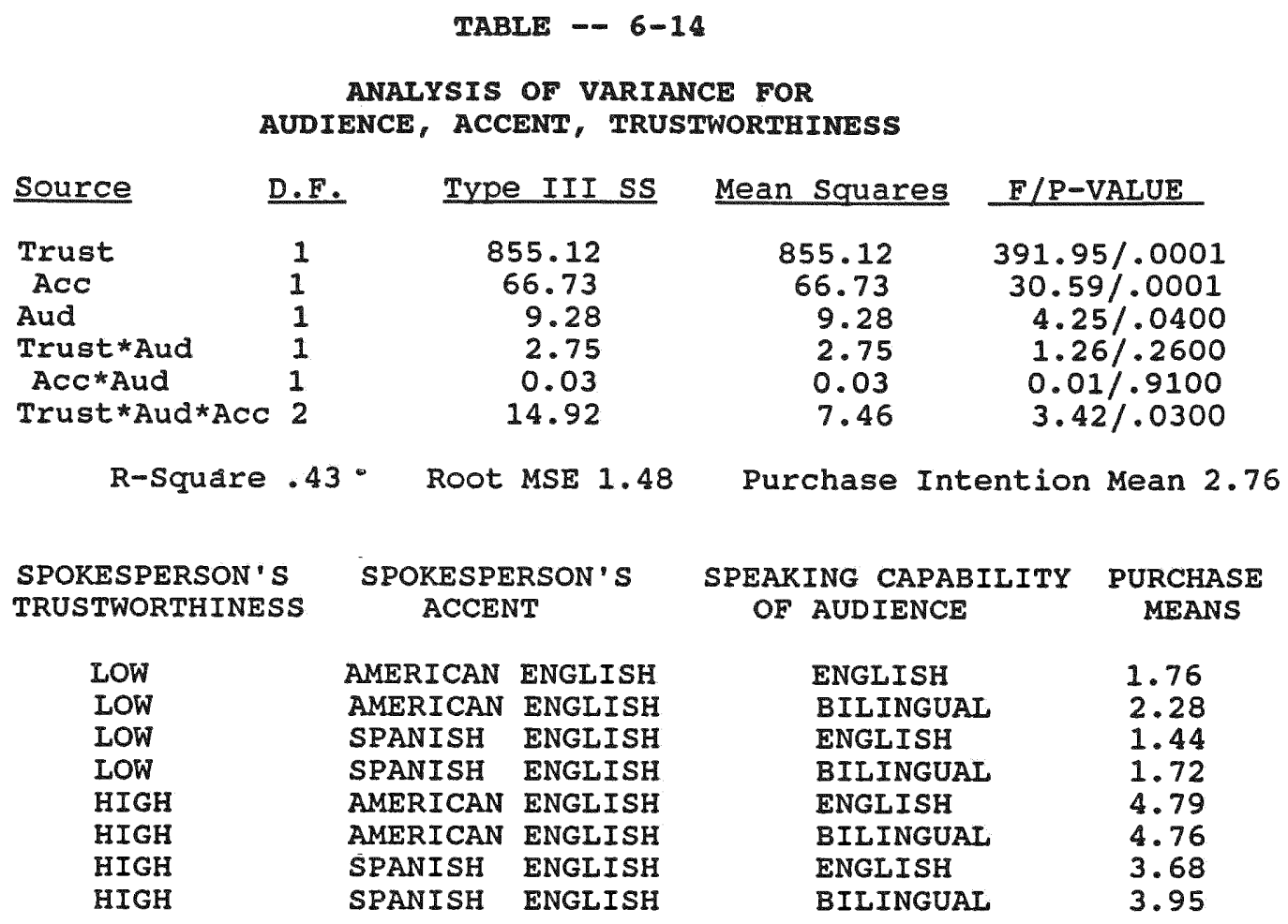

\section{LEGEND}

Trust--SPOKESPERSON'S TRUSTWORTHINESS

ACC----SPOKESPERSON'S ACCENT

Aud---LANGUAGE SPEAKING CAPABILITY OF THE RESPONDENTS

The analysis, also, shows that the two way interaction terms of spokesperson's expertise and the speaking capability of the audience ( F-Value $0.00, P<0.98)$ and the spokesperson's accent and the speaking capability of the audience (F-Value $0.22, \mathrm{P}<$ $0.64)$ are not statistically significant. The main effect of spokesperson's expertise (F-Value 361.06, $\mathrm{P}<0.0001$ ) is 
statistically significant. The moderating variables of spokesperson's accent ( $\mathrm{F}-$ Value $2.62, \mathrm{P}<0.11$ ) and the audience language speaking capability (F-Value 2.26, $\mathrm{P}<0.13$ ) are not statistically significant. As a result, $\mathrm{H}(0) 12 \mathrm{~A}$ and $\mathrm{H}(0) 12 \mathrm{~B}$ are not rejected.

\section{TABLE - 6-15 \\ ANALYSIS OF VARIANCE FOR \\ AUDIENCE, ACCENT, EXPERTISE}

\begin{tabular}{lcrrrr} 
Source & D.F. & Type III SS & Mean Squares & F/P-VALUE \\
\cline { 5 - 6 } Expert & 1 & 784.71 & & 784.71 & $361.06 / .0001$ \\
AcC & 1 & 5.69 & & 5.69 & $2.62 / .1100$ \\
Aud & 1 & 4.92 & & 4.92 & $2.26 / .1300$ \\
Expert*Aud & 1 & 0.00 & & 0.00 & $0.00 / .9800$ \\
Acc*Aud & 1 & 0.49 & & 0.49 & $0.22 / .6400$ \\
Expert*ACC*Aud & 2 & 1.16 & & 0.58 & $0.27 / .7700$
\end{tabular}

R-Square .31 Root MSE 1.50 Purchase Intention Mean 2.75

LEGEND

EXPET--SPOKESPERSON'S TRUUSTWORTHINESS

ACcent--SPOKESPERSON'S ACCENT

Audience--LANGUAGE SPEAKING CAPABILITY OF THE RESPONDENTS

\section{SUMMARY}

This chapter presents the research findings for the investigation of the impact of credibility of the spokesperson on consumers' purchase intentions. A summary of the major findings of the investigation is listed below:

1. An attractive spokesperson exerts more influence on consumers' purchase intentions than an unattractive spokesperson at the 0.08 level of significance (H1). 
2. A spokesperson with perceived trustworthiness has more influence on consumers' purchase intentions than a spokesperson lacking in trustworthiness (H2) .

3. A spokesperson with perceived expertise has more influence on consumers' purchase intentions than a spokesperson lacking in expertise (H3).

4. A statistically significant relationship was not found between spokesperson's attractiveness and the moderating variable consumer's involvement.

A statistically significant relationship was found the main effects of high or low attractiveness. Consequently, $\mathrm{H}(0) 4$ was not rejected.

5. A statistically significant relationship was found between a spokesperson who was perceived as having high trustworthiness and consumers who had high involvement with the service. Consequently, a spokesperson with trustworthiness makes a greater impact on consumers' purchase intentions when the item is viewed as a high involvement item than when it is viewed as a low involvement item. As a result, $\mathrm{H}(0) 5$ was rejected. 
6. A statistically significant relationship was found between a spokesperson who was perceived as having high expertise and consumers who had high involvement with the service. Consequently, a spokesperson with expertise makes a greater impact on consumers' purchase intentions when the item is viewed as a high involvement item than when it is viewed as a low involvement item. As a result, $\mathrm{H}(0) 6$ was rejected.

7. A statistically significant relationship was found between an attractive spokesperson's accent and the consumers' purchase intentions. An attractive American English spokesperson with an American English accent makes a greater impact on consumers' purchase intentions than an attractive spokesperson speaking with Cuban or Nicaraguan English accent. As a result, $\mathrm{H}(0) 7$ was rejected.

8. A statistically significant relationship was found between spokesperson's trustworthiness and accent on consumer's purchase intentions. A trustworthy spokesperson with an American accent makes a greater impact on consumers' purchase intentions than a trustworthy spokesperson speaking with Cuban or Nicaraguan English accent. As a result, $\mathrm{H}(0) 8$ was rejected. 
9. A statistically significant relationship was not found between spokesperson's expertise and accent. As a result, $\mathrm{H}(0) 9$ was not rejected.

10. A spokesperson who is perceived as attractive with an American English accent has a greater impact on purchase intentions of English speaking and Bilingual consumers than a perceived attractive spokesperson with a Cuban or Nicaraguan English accent. As a result, $\mathrm{H}(0) 10 \mathrm{~A}$ was rejected. Since a spokesperson's accent and the speaking capability of the audience; and spokesperson's attractiveness and the language speaking capability of the audience are not statistically significant $H(0) 10 B$ and $\mathrm{H}(0) 10 \mathrm{C}$ can be not rejected.

11. The purchase intentions of English speaking and Bilingual respondent's are different when they are listening to an audio presentation, but they are the same when they can see and hear the spokesperson. As a result, $H(0)$ 10D is not rejected when the audience can see the spokesperson, but $H(0) 10 D$ can be rejected when the audience can not see the spokesperson. 
12. A spokesperson who is perceived as trustworthy with an American English accent has a greater impact on purchase intentions of English speaking and Bilingual consumers than a perceived trustworthy spokesperson with a Cuban or Nicaraguan English accent. As a result, $\mathrm{H}(0) 11 \mathrm{~A}$ was rejected. A statistically significant relationship was not found between spokesperson's trustworthiness and the audience language speaking capability. As a result, $11(0)$ B was not rejected.

13. A statistically significant relationship was not found between: 1) audience language speaking capability, spokesperson's expertise and accent; and 2) spokesperson's expertise and audience language speaking capability. As a result, $\mathrm{H}(0) 12 \mathrm{~A}$ and $\mathrm{H}(0) 12 \mathrm{~B}$ were not rejected.

14. A statistically significant relationship was not found between audio-only presentation and involvement on purchase intentions; audio-only presentation and accent on purchase intentions; audio-only presentation and speaking capability of the audience on purchase intentions; and audio-only presentation, spokesperson's accent and speaking capability of the audience on purchase intentions. 
CHAPTER VII RESEARCH IMPLICATIONS, LIMITATIONS, AND

\section{EXTENSIONS}

This chapter examines both the managerial and academic implications of this research. The limitations of the study are discussed and areas for future research are presented.

\section{Managerial Implications}

The results of this investigation present four areas of interest or opportunities for advertising practitioners:

1. Spokesperson credibility should be evaluated when selecting an individual to represent a firm's product or service in an advertising campaign.

2. The spokesperson credibility model (SPCM) provides a systematic way, from a theoretical base, to select the spokesperson.

3. The most credible spokesperson's accent for a "nonstandard" or bilingual audience may not be a "nonstandard" spokesperson's accent.

4. A host country national rather than an expatriate spokesperson may be more effective for an advertising campaign in a foreign country. 
SPOKESPERSON CREDIBILITY IMPLICATIONS FOR PURCHASE INTENTIONS

The results of the study show that there is a relationship between the credibility of the spokesperson and purchase intentions of the consumer. Consequently, understanding the nature of this relationship is a prerequisite to selecting the most effective and efficient spokesperson to represent the firm's products or services. The issue of effectiveness and efficiency is especially important when the marginal return on investments on spokespersons is taken into account. For example, it may be critical to determine whether the same results using a celebrity can be achieved with a non-celebrity.

The expenditures for celebrities as spokespersons for various products and services have been substantial over the years (e.g., $\$ 25$ billion for product endorsements by celebrities in 1977; Polaroid's $\$ 3$ million for James Gardner; Bruce Willis' $\$ 2$ million for Seagram Golden Wine coolers; Mike Tyson's $\$ 3.5$ million for Diet Pepsi; Boris Becker's $\$ 560,000$ for Coca-Cola, $\$ 70,000$ for Ford, $\$ 630,000$ for Puma, and $\$ 560,000$ for Fila; Chris Evert's $\$ 500,000$ for Ellesse Tennis clothes, $\$ 100,000$ for Rolex watches, and $\$ 200,000$ for Lipton tea). These firms spent money on these celebrities believing that they provided a credible spokesperson for their products or services. They believed that the more credible the spokesperson, the more likely the spokesperson will have a positive influence on the consumers' purchase intentions. As noted earlier, the effectiveness of the spokesperson is also 
contingent on the context of the advertisement and the specific product that is being promoted. Consequently, a decoding theory that can explain how those expenditures can be made more efficiently and effectively will have positive implications for the firm.

\section{USING THE SPCM.TO SELECT THE SPOKESPERSON}

Haley, Richardson, and Baldwin (1984) indicated that nonverbal effects are especially important in persuasive communication. They also indicated that nonverbal factors (e.g., paralanguage, body language, physical attractiveness, music, semiotics, and setting) may produce negative or positive impact on commercials. This result is consistent with Haley's (1970) findings that individuals approach advertising messages suspiciously and are alert to any cues that are inconsistent with their expectations. This practice is complicated by the fact that not much is known about ways individuals assign meanings to the array of cues portrayed by spokespersons (Wackman, 1973).

The SPCM addresses these observations and concerns by specifying the relationship between three key aspects of spokesperson credibility and evaluating the impact of these aspects on consumers! purchase intentions. Also, the model takes into account the nature of the product or service, the voice characteristics of the spokesperson, and the ethnicity of the audience: factors that are crucial to the spokesperson selection decision. The model considers some nonverbal effects; for example, attractiveness, trustworthiness, and 
expertise. It also considers cues, for example, interaction of accent and audience characteristics. By using this multiple variable and nonverbal cue approach, the model was able to predict the type of spokesperson who would be most influential on consumers' purchase intentions. SPORESPERSON CREDIBILITY AND THE NATURE OF THE AUDIENCE

Tsalikis, DeShields, and LaTour (1991) noted that a salesperson with a standard English accent has an advantage over a salesperson addressing an English speaking audience in Greek-accented English. This result is consistent with the result of the present study and with the linguistic and social psychology literatures which propose that spokespersons speaking in the standard accent of the audience elicit more approval ratings of credibility than spokespersons speaking with a non-standard accent. The present study as well as Tsalikis, Deshields, and LaTour (1991) showed that there is no significant interaction between the respondents' exposure to an accent and respondents' evaluation of the accent. This consistent finding indicates an acculturation along the language pronunciation dimension of the new environment in which credibility is related to the language standard of the new host country. This observation is consistent with callon, Gallois, and Forbes' (1983) finding that:

"upwardly mobile ethnic minority groups favored the accent of the dominant majority, especially in the contexts where the advantages associated with the majority are salient" (p.423). 
It is therefore arguable that a minority spokesperson, may not be the most effective presenter for a firm's product and services to a minority group. Tajfel's (1981) theory suggests that minority spokespersons can be as effective as non-minorities if they are perceived as being a part of the mainstream, as being completely assimilated into the culture. Two minority spokespersons who meet this criterion are Michael Jordan and Bill Crosby. Michael Jordan is an effective spokesperson for Nike sports-wear because he is identified as the best player in the National Basketball Association; Bill Crosby is an effective spokesperson for a variety of products because he is identified as a top entertainer.

IMPLICATIONS FỌR THE DOMESTIC AND INTERNATIONAL MARRETS

This study has a number of implications for marketing in domestic and international advertising and sales. In the domestic arena, a significant implication for sales and advertising management is that spokespersons who speak the local dialect may be more effective than spokespersons who do not speak the local dialect, assuming all other variables affecting purchase intentions remain the same. Consequently, firms with domestic sales in areas with strong regional accents may want to consider local spokespersons for selling to those targeted areas.

In the international arena, the formation of the European Economic Community (EEC) in 1992 is expected to eliminate all trade barriers between member countries. However, the results of this study indicate that standard 
language pronunciations for each member country may be rated as superior to any accented version of the host country language, assuming that Europeans are somewhat ethnocentric. Consequently, an international sales force strategy for members of the EEC anticipating selling to member countries may want to consider using host country personnel as opposed to multilingual salespeople. Also, advertising in the respective countries may want to consider using a host country national.

\section{Research Implications}

Determinants of spokesperson credibility have been investigated over the years by academics and practitioners. Based on the objectives and findings of this study, three key areas may be of further research interest:

1. The ability of Tajfel's decoding theory to explain the relationship between spokespersons' credibility and consumers' purchase intentions.

2. The ability of the expanded spokesperson Credibility Model to represent the relationship between consumers purchase intentions and spokespersons. 
3. The generalizability and validity of research of the spokesperson Credibility Model when applied to
a bilingual audience, with a non-celebrity spokesperson.

\section{TAJFEL'S DECODING THEORY}

The research findings of this investigation indicated that Tajfel's social categorization, social identity, and social comparison theory (CIC) provides a useful way to explain how spokespersons' credibility influences consumers' purchase intentions. According to the theory, individuals evaluate others by categorizing them into various groups. Drawing on those categories, they decide on persons with whom to identify, consequently engaging in self-comparison. This notion provides the basis for explaining some counter intuitive findings. It should be noted that the basis of comparison is the mainstream of society or the standards set by dominant or powerful groups.

Two critical findings emerge from the present study: 1) there are no differences in the results of an English-only speaking audience and a bilingual audience's evaluation of a Spanish accented spokesperson, and 2) a bilingual audience will be influenced more by an English-accented spokesperson than by a spanish-accented spokesperson. These findings can easily be explained by Tajfel's theory. In both cases, the English language standard, assuming everything else is equal, provides the basis of comparison or the standard of legitimacy. 
EXPANDED SPORESPERSON CREDIBILITY MODEL

As noted earlier, Ohanian's (1991) study came closest to linking three factors of spokesperson credibility-attractiveness, trustworthiness, and expertise--and specifying the relationship between them and consumers' purchase intentions. The results of Ohanian's (1991) study indicated that expertise is the only statistically significant construct, suggesting some inconsistencies with earlier reports of the significant impact of attractiveness and trustworthiness on spokesperson credibility.

Based on the issues raised in Ohanian's (1991) study, the present study developed an expanded spokesperson credibility model by adding three moderating variables: involvement, spokesperson accent, and the audience language speaking capability. The model was tested by using noncelebrity spokespersons, a personal buying situation rather than a gift buying situation, and bilingual and English speaking audiences. The research findings for the expanded model indicate that the three main effect constructs-attractiveness, trustworthiness, and expertise--are statistically significant. The interaction between involvement (a moderating variable) and expertise is statistically significant. The interaction between accent, attractiveness; and trustworthiness is statistically significant. There is a statistically significant difference between purchase intentions of English and bilingual audiences. Because of these findings, the expanded 
spokesperson credibility model was able to reconcile the inconsistencies found in Ohanian's (1991) results and findings in the marketing literature.

\section{GENERALIZABILITY AND VALIDITY OF THE RESEARCH}

This study has.a sample size of 1,162 participants of whom 199 are non-students and 963 students. The sample is multi-ethnic and is representative of south Florida. Also, the use of two spokespersons for each accent and the inclusion of both Cuban and Nicaraguan English accents provide a basis to generalize the findings to spanish speaking audiences and spokespersons. Also, multiple models for attractiveness were used to improve the external validity of the study.

The experimental design used for the study insured a high degree of internal validity. Also, a variety of additional procedures tested the internal validity of the instrument. Cronbach alphas indicate a high degree of reliability for the items in the instrument. Exploratory and confirmatory factor analyses give additional insights into the convergent and discriminant validity of the constructs used in the study.

\section{Limitations of the study}

Since the study focused on accents, the influence of spokespersons' dialect was not assessed. Also, all spokespersons were men. Consequently, the results of the study can only be applied to men. Additionally, projections of the results to international settings are questionable because of the characteristics of the sample population. 
Another shortcoming is that the study does not address race. Although steps were taken to purify the scale that was used to measure the latent variables, caution should be exercised when interpreting how well these observed variables reflected the latent variables. The modification index for the LISREL model and an exploratory factor analysis for the indicator variables used in the model indicate that there are still some overlapping variables present--loading onto two structures simultaneously (Table $7-1$ and 7-2). The modification index in Table 7-1 indicates that the honest and trustworthy indicator variables for the trustworthiness construct, also, loads onto the expertise construct. The exploratory factory analysis, also, indicates that the honest and trustworthy indicator variables loads onto the expertise construct. As a result, for this particular population spokesperson's who are perceived as being honest and trustworthy are, also, perceived as having some expertise. 


\section{TABLE 7-1}

MODIFICATION INDICES AND ESTIMATED CHANGE FOR LISREL MODEL

MODIFICATION INDICES FOR LAMDA $x$

ATTRACTIVENESS TRUSTWORTHINESS EXPERTISE PURCHASE

$\begin{array}{lrrrr}\text { ATTRACTIVE } & .000 & .000 & .071 & .015 \\ \text { BEAUTIFUL } & .000 & .002 & .136 & .285 \\ \text { SEXY } & .000 & .180 & .002 & .006 \\ \text { ELEGANT } & .000 & .773 & 1.427 & 1.344 \\ \text { HONEST } & .000 & .000 & 2.303 & 1.071 \\ \text { SINCERE } & .205 & .000 & .692 & .165 \\ \text { TRUSTWORTHY } & .156 & .000 & 4.792 & 1.790 \\ \text { EXPERT } & .041 & .138 & .000 & .665 \\ \text { EXPERIENCED } & 1.569 & 1.672 & .000 & .928 \\ \text { KNOWLEDGEABLE } & .037 & .245 & .000 & .006 \\ \text { QUALIFIED } & .219 & 1.680 & .000 & .334 \\ \text { SKILLED } & 1.330 & .021 & .000 & .235 \\ \text { PURCHASE } & .172 & 2.159 & 3.999 & .000 \\ \text { INQUIRE } & .047 & .352 & .400 & .000 \\ \text { CONSIDER } & .347 & .728 & 1.835 & .000\end{array}$

ESTIMATED CHANGE FOR LAMBDA $X$ ATTRACTIVENESS TRUSTWORTHINESS EXPERTISE PURCHASE

\begin{tabular}{|c|c|c|c|c|}
\hline ATTRACTIVE & .000 & -.002 & -.023 & -.012 \\
\hline BEAUTIFUL & .000 & -.003 & -.025 & -.041 \\
\hline SEXY & .000 & -.034 & .003 & .006 \\
\hline ELEGANT & .000 & .080 & .093 & .101 \\
\hline HONEST & .002 & .000 & -.176 & -.128 \\
\hline SINCERE & -.045 & .000 & -.105 & -.055 \\
\hline TRUSTWORTHY & .038 & .000 & .266 & .17 \\
\hline EXPERT & -.016 & -.042 & .000 & .08 \\
\hline EXPERIENCED & -.106 & -.154 & .000 & -.103 \\
\hline KNOWLEDGE & .016 & .060 & .000 & -.00 \\
\hline QUALIFIED & .039 & .148 & .000 & .05 \\
\hline SKILLED & .093 & .016 & .000 & -.04 \\
\hline PURCHASE &. $.037^{\circ}$ & .175 & .188 & .00 \\
\hline INQUIRE & .025 & -.096 & -.081 & .00 \\
\hline CONSIDER & -.066 & -.131 & -.168 & .000 \\
\hline
\end{tabular}




\section{TABLE 7-1 (CONTINUED)}

MODIFICATION INDICES FOR THETA DELTA $\begin{array}{lllll}\text { VAR15 VAR12 VARO9 VARO6 VAR02 VAR08 } & \text { VAR }\end{array}$

$\begin{array}{lrrrrrr}\text { VAR15 } & .000 & & & & & \\ \text { VAR12 } & .801 & .000 & & & & \\ \text { VAR09 } & .008 & .145 & .000 & & & \\ \text { VAR06 } & 1.675 & .053 & .455 & .000 & & \\ \text { VAR02 } & .007 & .360 & .258 & .091 & .000 & \\ \text { VAR08 } & .061 & .065 & .379 & .000 & 4.851 & .000 \\ \text { VAR11 } & .194 & .000 & .109 & .102 & .748 & 2.118 \\ \text { VAR01 } & .074 & .0252 & .022 & .150 & .375 & .278 \\ \text { VAR04 } & .305 & 1.190 & .000 & .031 & .848 & .455 \\ \text { VAR07 } & .044 & .112 & .040 & .409 & .026 & .437 \\ \text { VAR10 } & .042 & .012 & .033 & .013 & .212 & .212 \\ \text { VAR13 } & .076 & 1.437 & .068 & .309 & .000 & .020 \\ \text { VAR16 } & .002 & .139 & .084 & .191 & .011 & .109 \\ \text { VAR17 } & .021 & .000 & .053 & .112 & .043 & .019 \\ \text { VAR18 } & .008 & .00350 & .001 & .068 & .072 & .018 \\ & & & & & & \\ & \text { VAR11 } & \text { VAR01 } & \text { VAR04 } & \text { VAR07 } & \text { VAR10 } & \text { VAR13 }\end{array}$

$\begin{array}{lrrrrrr}\text { VAR11 } & .000 & & & & & \\ \text { VAR01 } & .006 & .000 & & & & \\ \text { VAR04 } & .018 & 3.037 & .000 & & & \\ \text { VAR07 } & .004 & .450 & .025 & .000 & & \\ \text { VAR10 } & 4.260 & .257 & .001 & .708 & .000 & \\ \text { VAR13 } & .004 & 1.452 & .031 & 2.539 & .016 & .000 \\ \text { VAR16 } & .294 & 1.696 & .0310 & .010 & .408 & .001 \\ \text { VAR17 } & .044 & .081 & .277 & .047 & .005 & .292 \\ \text { VAR18 } & .012 & .002 & .475 & .082 & .087 & .487 \\ & \text { VAR16 } & \text { VAR17 } & \text { VAR18 } & & & \\ & & & & & & \\ \text { VAR16 } & .000 & & & & & \\ \text { VAR17 } & 2.069 & .000 & & & & \\ \text { VAR18 } & .424 & 4.439 & .000 & & \end{array}$


TABLE 7-1 (CONTINUED)

ESTIMATED CHANGE FOR THETA DELTA

\begin{tabular}{|c|c|c|c|c|c|c|}
\hline & VAR15 & VAR12 & VAR09 & VAR0 6 & VAR02 & VAR0 8 \\
\hline VAR15 & .000 & & & & & \\
\hline VAR12 & .116 & .000 & & & & \\
\hline VARO9 & .010 & -.036 & .000 & & & \\
\hline VAR06 & -.144 & -.021 & .060 & .000 & & \\
\hline VARO2 & .008 & .048 & -.045 & .028 & .000 & \\
\hline VAR08 & -.025 & .023 & -.061 & .002 & .157 & .000 \\
\hline VAR11 & .040 & .000 & -.029 & -.031 & -.071 & -.119 \\
\hline VAR01 & -.024 & -.040 & .012 & .035 & -.046 & -.043 \\
\hline VAR0 4 & -.053 & -.096 & .001 & .017 & -.076 & -.059 \\
\hline VAR07 & -.020 & .028 & -.018 & .065 & .013 & .054 \\
\hline VAR10 & .019 & -.009 & .016 & .011 & -.035 & -.037 \\
\hline VAR13 & .024 & .093 & .022 & .053 & .001 & .011 \\
\hline VAR16 & -.004 & -.031 & .025 & .042 & -.008 & .025 \\
\hline VAR17 & .017 & .001 & .025 & .041 & -.020 & -.014 \\
\hline \multirow[t]{2}{*}{ VAR18 } & -.009 & -.059 & .003 & .030 & -.024 & -.013 \\
\hline & VAR11 & VARO1 & VAR0 4 & VAR07 & VAR10 & VAR13 \\
\hline VAR11 & .000 & & & & & \\
\hline VAR01 & -.005 & .000 & & & & \\
\hline VARO 4 & .010 &.$\quad .129$ & .000 & & & \\
\hline VAR07 & .005 & -.044 & -.010 & .000 & & \\
\hline VAR10 & .128 & -.032 & .002 & -.052 & .000 & \\
\hline VAR13 & .004 & -.076 & -.011 & .086 & .007 & .000 \\
\hline VAR1 6 & .037 & .078 & .037 & .007 & .040 & .003 \\
\hline VAR17 & -.019 & .023 & -.048 & -.021 & -.006 & -.048 \\
\hline \multirow[t]{2}{*}{ VAR 18} & .009 & -.004 & -.058 & -.025 & -.023 & -.058 \\
\hline & VAR1 6 & VAR17 & VAR18 & & & \\
\hline VAR 16 & .000 & & & & & \\
\hline VAR17 & -.110 & .000 & & & & \\
\hline VAR18 & -.057 & .226 & .000 & & & \\
\hline
\end{tabular}

MAXIMUM MODIFICATION ${ }^{\circ}$ INDEX IS 4.85 FOR ELEMENT $(6,5)$ OF THETA DELTA

\section{LEGEND}

\section{ATTRACTIVENESS}

VAR 15--ATTRACTIVE

VAR 12--BEAUTIFUL

VAR 09--SEXY

VAR 06--ELEGANT

PURCHASE INTENTIONS
TRUSTWORTHINESS

VAR 11--TRUSTWORTHY VAR 01--EXPERT

VAR 02--HONEST

VAR 08--SINCERE

VAR 04--EXPERIENCE

VAR 07-KNOWLEDGEABLE

VAR 10--QUALIFIED

VAR 13--SKILLED

VAR 16--PURCHASE

VAR 17--INQUIRE

VAR 18--CONSIDER 
TABLE 7-2

EXPLORATORY FACTOR ANAIYSIS--SPOKESPERSON CREDIBILITY MODEL

Rotation Method: Varimax

Rotated Factor Pattern

FACTOR1 FACTOR2 FACTOR3 FACTOR4

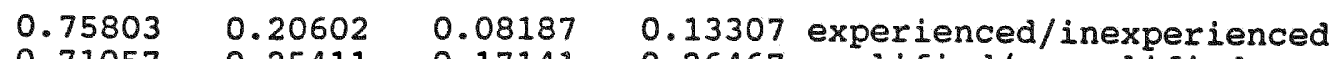

$\begin{array}{llll}0.71057 & 0.25411 & 0.17141 & 0.26467 \\ \text { qualified/unqualified }\end{array}$

$\begin{array}{llll}0.66757 & 0.16176 & 0.24238 & 0.26359 \\ \text { skilled/unskilled }\end{array}$

$\begin{array}{llll}0.64621 & 0.16444 & 0.16919 & 0.29503 \\ \text { knowledge/unknowledge }\end{array}$

\begin{tabular}{llll}
0.64095 & 0.28410 & 0.11380 & 0.12355 \\
\hline
\end{tabular}

$\begin{array}{llll}0.29054 & 0.81589 & 0.14832 & 0.25571 \\ \text { consider/not consider }\end{array}$

$0.27914 \quad 0.79386 \quad 0.16141 \quad 0.23447$ inquire/not inquire

$\begin{array}{lllll}0.34388 & 0.69735 & 0.17200 & 0.24492 & \text { purchase/not purchase }\end{array}$

$\begin{array}{llll}0.11431 & 0.11016 & 0.75325 & 0.15493 \text { attractive/unattractive }\end{array}$

$0.087160 .05064 .0 .73588 \quad 0.19725$ beautiful/ugly

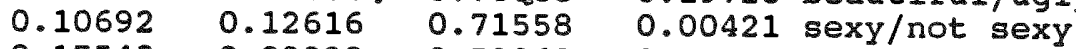

\begin{tabular}{llll}
0.17543 & 0.09823 & 0.52860 & 0.06713 \\
\hline
\end{tabular}

$\begin{array}{llll}0.24460 & 0.20627 & 0.11688 & 0.67389 \\ \text { sincere/insincere }\end{array}$

$0.18711 \quad 0.18207 \quad 0.13701 \quad 0.64986$ honest/dishonest

$\begin{array}{llll}0.33623 & 0.25448 & 0.16313 & 0.61707 \text { trustworthy/untrustworthy }\end{array}$

\section{Research Extensions}

The following research topics are potential areas of investigation:

A) A follow-up study using multidimensional scaling techniques to select an ideal spokesperson for a particular product or service for a target market audience. - Use the theory and methods in this dissertation, conduct a test to determine whether the ideal spokesperson is selected from a group of other spokespersons for the particular item and audience. 
B) A follow-up study to determine whether there is a difference between credible spokesmen and spokeswomen for the same product or service and target audience--gender effects.

C) A follow-up study to determine whether there is a difference between credible spokespersons' of different races for the same product or service and target audience.

D) A follow-up study to determine for which products and services female and ethnic spokespersons have the highest credibility.

E) A follow-up study to determine whether importance of various spokesperson credibility factors differ in by country and language.

F) A follow-up study to test the generalizability of the results (duplicate the study in various foreign countries by using a variety of spokespersons' accents).

\section{Summary}

The results of the dissertation provide managers with a decoding theory and method to help them select a spokesperson who would be most effective for a particular product or service for a targeted audience. Consequently, practitioners 
are able to allocate advertising expenditures more efficiently and effectively. Academicians are provided a useful way of explaining the impact of the spokesperson on consumers' purchase intentions.

The limitations of the study are primarily directed at the sampling population and the spokespersons used for the study. As a result, extending the sampling population, type of spokespersor, and languages or accents is expected to make the proposed decoding theory and results more generalizable.

A variety of potential studies that could contribute to the marketing literature and benefit practitioners were suggested. For example, identifying the type of markets and services for which women and ethnic groups are more credible than mainstream spokespersons would enable practitioners to allocate their advertising expenditures more efficiently. Making the findings more generalizable would enable practitioners to use the decoding theory and method in a variety of domestic and international settings. 
APPENDIX A - QUESTIONNAIRE 


$$
\text { C.N. I.D. } \overline{1.1} \overline{\frac{1.2}{1.4}} \overline{1.3}
$$

Based on the message you just heard, give us your opinion of the spokesperson by placing an $\mathrm{X}$ in the appropriate column.

Expert
Experienced
Unknowledgeable:
Qualified
Unskilled
Dependable
Dishonest
Reliable
Insincere
Trustworthy
Attractive
classy
Plain
Sexy
Ugly


Based on your understanding of automobile insurance, give us your opinion of the necessity of the service to you, by placing an $\mathrm{x}$ in the appropriate column.

Important :______:_ :_______ Unimportant 1.20 of No Concern Irrelevant Means A Lot To Me

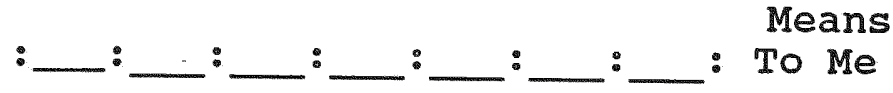

Useless

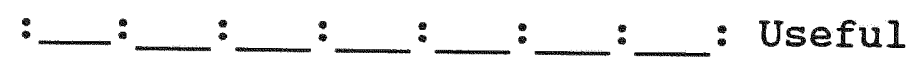

Valuable

Trivial

Beneficial :__________________ Worthless Matters To Me :___________________ Fundamental $\therefore$ ____:____________ Not Beneficial Uninterested significant :__ :______________ Doesn't Matter Vital
Boring Vital $:[\ldots$ ________________ Interested

Unexciting : :___ Insignificant $:\left[\_\right.$________________: Superfluous Appealing

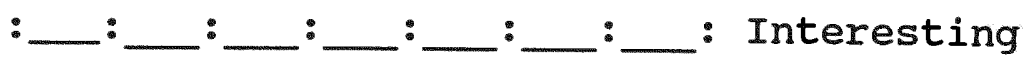
Mundane $\therefore$ ____: ______________ Exciting Essential

$$
\text { : }
$$
: : Unappealing Undesirable :__ :_______________ Fascinating Wanted Not Needed :_________________ Nonessential :_________________: Desirable

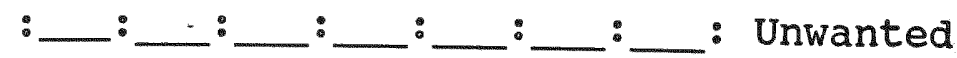
:___________ : _ : _ _ : Needed 1.39 
1. How likely would you purchase an insurance policy $\underline{1.40}$ from this person?

Purchase :__________________________ Would not Purchase

Consider :______________________ Not Consider

Inquire : __ : _ _ ______________ Not Inquire

2.* In evaluating the previous speaker, which of the following characteristics of his voice influenced you the most?

Intonation (tone)

Pleasant :____________________ Unpleasant

Speed (speaking rate)

Fast
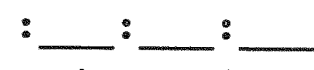

$:$ _____: Slow

Accent (ability to be understood)

Easy : : : : : : Hard

2a.* In evaluating the previous speaker, what characteristics of his voice influence you the most?

* Will be given to half of the respondents. 


\section{BACKGROUND INFORMATION}

1. Sex Male $\frac{}{1}$ Female $\frac{}{0}$

2. What is your native/first language?

English 1

other (please print)

3. What is your parents' native language?

Mother

Father

4. What language(s) do you speak with your parents?

Mother

Father

5. What language(s) do you speak with your children?

6. What language(s) do you speak with your co-workers?

7. What country was your mother born?

8. What country was your father born?

9. a) In which country were you born?

b) If you were not born in the U.S.A., which year did you take up residence in this county?

10. Which of the following best describes your ethnic group?

a) Anglo (Caucasian)

b) African American

c) Hispanic or Spanish

1) Cuban

2) Mexican

3) Puerto Rican

4) Other Hispanic

d) Other (please print)

11. What is your current age?
a) $18-24$
b) $25-29$
c) $30-35$
d) $35-44$
e) $45-54$
f) $55-64$
g) 65 and over 
12. What is the highest level of formal education that you have completed? (Please check one)
a) Grades 1-8
b) Grades $9-1 \overline{1}$
c) Graduated High School
d) Technical School
e) First year of college
f) Second year of college
g) Third year of college
h) Gradate college
i) Attended or completed Graduate school
j) Don't know

13. Which of the following best describes your occupation?

a) Professional or managerial

b) Technical, sales, administrative support

c) Service

d) Farming, forestry, fishing

e) Precision production, craft and repair

f) Operator or laborer

g) Student

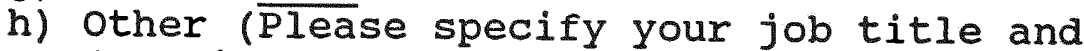
describe briefly what do)

14. What was your total household income in 1990 from all 1.63 source before taxes? (Please include here all income in your household). Please check one.
a) less than $\$ 5,000$
b) $\$ 5,000$ to $\$ 9,99$
c) $\$ 10,000$ to $\$ 19,999$
d) $\$ 20,000$ to $\$ 29,999$
e) $\$ 30,000$ to $\$ 39,999$
f) $\$ 40,000$ to $\$ 49,999$
g) $\$ .50,000$ to $\$ 74,999$
h) $\$ 75,000$ to $\$ 99,999$
i) $\$ 100,000$ and over 
APPENDIX B - BIBLIOGRAPHY 


\section{BIBLIOGRAPHY}

Aaker, D. A., \& Myers, J. G. (1987). Advertising management (3rd ed.). Engelwood Cliffs, NJ: Pentice-Hall.

Allport, G. W. (1954) . The nature of prejudice. Cambridge, Ma.: Addison-Wesley.

Alpert, M. I., \& Anderson, W. T. Jr., (1973). Optimal heterophily and communication effectiveness: Some empirical findings. Journal of Communications, 23, $328-343$.

Andersen, S. M., \& Klatzky R. R. (1987). Traits and social stereotypes: Levels of categorization in person perception. Journal of Personality and Social Psychology, 53, 235-246.

Anderson, N. H. (1974). Information integration: A brief survey. In D. H. Krantz, R. C. Atkinson, R. D. Luce, \& P. Suppes P.(Eds.), Contemporary developments in mathematical psychology (pp. 236-252). San Francisco: Freeman.

Anderson, J. R., (1983). A spreading activationt theory of memory. Journal of Verbal Learning and Verbal Behavior, 22, 261-29.5.

Anisfeld, M. , Bogo N., \& Lambert, W. E. (1962). Evaluational reactions to accented English speech. Journal of Abnormal and Social Psychology, 65, 223-231.

Arnold, H. J. (1982). Moderator variables: A classification of conceptual, analytic, and psychometric issues. organizational Behavior and Human Performance, 29, 143-174.

Aschmore, R. D., \& Del Boca, F. K. (1981). Conceptual approaches to stereotypes and stereotyping. In D. L. Hamilton (Ed.), Cognitive processes in stereotyping and intergroup behavior (pp. 1-16). Hillsdale, NJ:

Erlbanum.

Ash, S. E. (1946). Forming impressions of personality. Journal of Abnormal and Social Psychology, 41, 258-290.

Baker, M. J., \& Churchill, G. A. Jr. (1977). The impact of physically attractive models on advertising evaluations. Journal of Marketing Research, 14, 538-555. 
Berechree, P., \& Ball, P. (1979). A study of sex, accentbroadness and Australian sociolinguistic identity. Paper presented at the second Australian conference on Language and Speech.

Berger, P. L. (1966). Identity as a problem in the sociology of Knowledge. European Journal of Sociology, 7, 105-115.

Berger, J., Fisek, M. H., Norman, R. Z., \& Zelditch, M. Jr. (1977). Status characteristics and social interaction: An expectation states approach. New York: Elsevier Scientific Publishing company.

Berk-Seligson, S. (1984). Subjective reactions to phonological variation in Costa Rican Spanish. Journal of Psycholinguistic Research, 13, 15-442.

Bernstein, B. B., (1962). Social class, linguistic codes and grammatical elements. Lanquage and Speech, $\underline{5}, 221-240$.

Berscheid, E., \& Walster, E. (1974). Physical attractiveness. In L. Berkowitz. (Ed.), Advances in experimental social psychology. New York: Academic Press.

Blass, T., Alperstein, L., \& Block, S. H. (1974). Effects of communicator's race and beauty and of receiver's objectivity-subjectivity on attitude change. Proceedings of the Division of Personality and Social Psychology. (pp. 132-134). Washington: American Psychological Association.

Bollen, K. A. (1989). Structural Equation with Latent Variables. New York: Wiley.

Bone, P. F., Ellen, 'P. S., Easley, R. W., \& McNeely, S. E. (1986). A comment on relationship between source expertise and source similarity in an advertising context. Journal of Advertising, 15, 47-48.

Bourhis, R. Y., \& Giles, H. (1976). The language of cooperation in Wales: A field study. Language Sciences, 42, 13-16.

Bourhis, R. Y., \& Giles, H. (1977). The language of intergroup distinctiveness. In R. Y. Bourhis, \& H. Giles (Eds). Language, Ethnicity, and Intergroup Relation.

(pp. 119-135). London: Academic Press.

Botha, E. (1968). Verbally expressed values of bilinguals. Journal of Social Psychology, 75, 159-164. 
Bourhis, R. Y., Giles, H., Leyens, J. P., \& Tajfel, H. (1979). Psycholinguistic distinctiveness: Language divergence in Belgium. In R. Y. Bourhis, \& H. Giles (Eds.). Lanquage And Social Psychology. (pp. 158-185). Oxford: Blackwell press.

Bovee, C. L. \& Arens; W. F. (1989). Contemporary advertising (3rd. Ed.). Homewood, Il: Irwin.

Bradac, J. J., \& Wisegarver, R. (1984). Ascribed status, lexical diversity, and accent: Determinants of perceived status, solidarity, and control of speech style. Journal of Language and Social Psychology, 3, 239-255.

Breakwell, G. (1979), Illegitimate membership and intergroup differentiation. British Journal of Clinical Psychology. 18, 141-149.

Brennan, E. M... \& Brennan, J. C. (1981). Measurements of accent and attitude toward Mexican-American speech. Journal of Psycholinguistic Research, 10, 487-501.

Brennan, E. M., \& Brennan, J. C. (1983). Accent scaling and language attitudes: reaction to Mexican-American English speech. Language and Speech, 24(3), 207-221.

Brennan, E. M., Ryan, E. B. \& Dawson, W. E. (1975). Scaling of apparent accentedness by magnitude estimation and sensory modality matching. Journal of Psycholinguistic Research, $\underline{4}, 27-36$.

Brock, T. C. (1965). Communicator-recipient similarity and decision change. Journal of Personality and Social Psychology, 1, 650-654.

Brown, B. L., Giles, H., \& Thakerar, J. N. (1985). Speaker evaluations as a function of speech rate, accent and context. Language and Communication, 5, 207-220.

Cacippo, J. T., \& Schumann, D. (1983). Central and peripheral routes to advertising effectiveness: The moderating role of involvement. Journal of Consumer Research, 10, 135-144.

Callan, V. J., Gallois, C., \& Forbes, P. A. (1983). Valuative reactions to accented English. Journal of Cross-cultural Psychology, 14, 407-426.

Campbell, D. T. (1956). Enhancement of contrast as composite habit. Journal of Abnormal Social Psychology, 3 , 
Carranza, M. \& E. Ryan, E. (1975). Evaluative reactions of bilingual Anglo and Mexican American adolescents toward speakers of English and Spanish. International Journal of the sociology of Language, $6,83-104$.

Cavior, N., \& Dokecki, P. R. (1971). Physical attractiveness self concept: A test of Mead's hypothesis. Proceedings of the 79th Annual convention of the American Psychological Association, $6,319-320$.

Celsi, R. L., \& Olson, J. C. (1988). The role of involvement in attention and comprehension processes. Journal of Consumer Research, 15, 210-224.

Chaiken, S. (1979). Communicator physical attractiveness and persuasion. Journal of Personality and Social Psychology, 37, 1387-1397.

Chaiken, S. (1980). Heuristic versus systematic information processing and the use of source versus message cues in persuasion. Journal of Personality and Social Psychology, 39, 752-766.

Chaiken, S. (1986). Physical appearance and social influence. In C. P. Herman, M. P. Zanna \& E. T. Higgins (Eds.). Physical appearance, stigma, and social behavior.

(pp. 143-177). New Jersey: Erlbraum Associates.

Chaiken, S. (1987). The heuristic model of persuasion. In M. P. Zanna, J. M. Olson, \& C. P. Herman (Eds.). Social Influence: The ontario symposium. (pp. 3-39). 5 . Hillsdale, NJ: Erlbraum.

Chaiken, S. \& Eagley, A. H. (1974). Communication modality as A determinant of message persuasiveness and message comprehensibility. Journal of Personality and Social Psychology, 34, 605-614.

Chase, W. G. \& Simon, H. A. (1973). Perceptions in chess. Cognitive Psychology, $\underline{4}, 55-81$.

Childers, T. L. \& Houston, M. L. (1984). Conditions for picture-superiority effects on consumer memory. Journal of Consumer Research, 11, 643-653.

Choo, K. K. (1964). Communicator credibility and communication discrepancy as determinants of opinion change. Journal of Social Psychology, 64, 1-20.

Churchill, G. A. Jr. (1979). A paradigm for developing better measures of marketing constructs. Journal of Marketing
Research, 16, 64-73. 
Cohen, E. G., \& Roper, S. S. (1972). Modification of interracial interaction disability: An application of status characteristics theory. American Sociological Review, 37, 643-655).

Compos, A., \& Astorga, V. M. (1986). Spanish, North American, and Canadian ratings of imagery values of words. Perceptual and Motor Skills, 63, 889-890.

Cooper, R. L. (1975). Language attitudes II. International Journal of The Sociology of Language, $\underline{6}, 5-10$.

Dion, K., \& Stein, S. (1978). Physical attractiveness and interpersonal influence. Journal of Experimental Social Psychology, 14, 97-108.

Doise, W., Deschamps, J. C., \& Meyer, G. (1978). The accentuation of intercategory similarities. In W. Doise, H. C. Dechamps, \& G. Meyer (Eds.). Differentiation between social groups: Studies In the social psychology of intergroup relations. (pp. 159-168). London: Academic Press.

Doise, W., Sinclair, A., \& Bourhis, R. Y. (1976). Evaluation of accent convergence and divergence in cooperative and competitive intergroup situations. British Journal of Social Clinical Psychology, 15, 247-252.

Doob, L. W. (1977). The effect of language on verbal expression and recall. American Anthropologist, 59 , 88-100.

Eagly, A. H., (1974). Comprehensibility of persuasive arguments as a determinant of opinion change. Journal of Personality and Social Psychology, 29, 758-773.

Eagly, A. H., \& Chaiken, S. (1984). Cognitive theories of persuasion. In L. Berkowitz (Ed.). Advances in Experimental Social Psychology, 17, (pp. 267-359). New York: Academic Press.

Eagly, A. H., \& Wood, W. (1985). Gender and influencability: stereotypes versus behavior. In V. E. O'Leary, R. K. Unger, \& B. S. Wallston (Eds.). Women Gender and Social Psychology, (pp. 225-256). Hillside, NJ: Lawrence Erlbaum.

Earle, M. J., (1967). Bilingual semantic merging and an aspect of acculturation. Journal of Personality and 
Eastlack, J. O. Jr. (1984/1985). Point of view: How to take the controversy out of TV copy testing. Journal of Advertising Research, 24, 37-39.

Edwards, J. (1982). Language attitudes and implications among English speakers. Language and Speech, 20-33.

Edwards, J., \& Jacobsen, M. (1987). Standard and regional standard speech: Distinctions and similarities. Lanquage in Society, 16, 369-380.

Engel, J. F., Blackwell, R. D., \& Miniard, P. W. (1990). Consumer Behavior. (6th Ed.). Chicago: The Dryden Press.

Ervin, S. M. (1964). Language and TAT content in bilinguals. Journal of Personality and Social Psychology, 6, 500-507.

Fazio, R. H., Powell, M. C., \& Herr, P. M. (1983). Toward a process model of the attitude-behavior relation: Accessing one's attitude upon mere observation of the attitude object. Journal of Personality and Social Psychology, 44,723-735.

Festinger, L. (1954). A theory of social comparison process. Human Relations, 7, 117-140.

Fishbein, M., \& Ajzen, I. (1975). Belief, attitude, intention, and behavior: An introduction to theory and research. Reading, Ma: Addison-Wesley.

Fiske, S. T. \& Pavelchak, M. A. (1986). Category-based versus piecemeal-based affective responses: Developments in schema-triggered affect. In R. M. Higgins and E.T. Higgins (Eds.) The Handbook of motivation and cognition: Foundations of social behavior sorrentino. (pp. 167-203). New York: Guilford Press.

Flores, N. de la Z, \& Hopper, R. (1975). Mexican Americans' evaluations of spoken Spanish and English. Speech Monographs, 42, 91-98.

Foon, A. E. (1986). A social structural approach to speech evaluation. The Journal of Social Psychology, 126, 521-530.

Frandsen, K. D. (1963). Effects of threat appeals and media of transmission. Speech Monographs, 30, 101-104.

Friedman, H. H. \& Friedman, I. (1976). Whom do students trust? Journal of Communication, $\underline{26}, 48-49$. 
Friedman, H. H., Santeramo, M. J., \& Traina, A. (1979). Correlates of trustworthiness for celebrities. Journal of Academy of Marketing Science, $6,291-299$.

Gallois, C., \& Callan, V. J. (1981). Personality impressions elicited by accented English speech. Journal of CrossCultural Psychology, 12, 347-359.

Garcia, M. R. I. (1984). Speech attitudes to speakers of language varieties in a bilingual situation. International Journal of Society and Language, 47, 73-90.

Giles, H. (1970). Evaluative Reactions to Accents. Educational Review, 22, 11-27.

Giles, H. (1971). Patterns of evaluation in reactions to PR, South Welch and Somerset accented speech. British Journal of Social and Clinical Psychology, 10, 280-81.

Giles, H. (1973). Accent mobility: A model and some data. Anthropological Linguistics, 15, 87-105.

Giles, H., Bourhis, R. Y. \& Taylor, D. M. (1977). Toward a theory of language in ethnic group relations. In $\mathrm{H}$. Giles (Ed.). Language, ethnicity, and intergroup relations. (pp. 307-348). "London: Academic Press.

Giles, H. (1980). Ethnicity markers in speech. In K. R. Scherer \& H. Giles (Eds.). (pp. 251-289). Social Markers in Speech. Cambridge University Press: Cambridge, England.

Giles, H., Baker, S. \& Fielding, G. (1975). Communication length as a behavioral index of accent prejudice. International Journal of the Sociology of Language, 40, 961-962.

Giles, H., \& Bouhris, R. Y. (1975). Linguistic assimilation among West Indian immigrants in a British City. Language Sciences, $38,9-12$.

Giles, H., \& Bouhris, R. Y. (1976). Black Speakers with white speech--A real problem? In G. Nickel (Ed.). Proceedings of the Fourth International congress of Applied Linguistics. Stuttgart: Hochshul Verlag.

Giles, H., \& Sassoon, C. (1983). The effect of speaker's accent, social 'class background and message style on British listeners' social judgments. Language and communication, 3, 305-313. 
Giles, H., \& Powesland, P. F. (1975). Speech style and social evaluation. Journal of Multilingual and Multicultural Development, 207-223.

Giles, H., \& Johnson, P. (1981). The role of language in ethnic group relations. In J. C. Turner \& G. Howard (Eds.). Intergroup behavior. (pp. 199-243). Oxford: Blackwell Press.

Green, P. E.; Carmone, F. J. \& Smith, S. M. (1989). Multidimensional scaling: Concepts and applications. Needham Heights; Ma: Allyn and Bacon.

Harmo, R. R., \& Coney, K. A. (1982). The persuasive effects of source credibility in buy and lease situations. Journal of Marketing Research, 19, 255-260.

Haley, R. L. (1970). Marketing implications of selective perception. Paper Presented at the Annual Meeting of the American Association of Public Opinion Research, Lake George, NY.

Haley, R. L., Richardson, J. \& Baldwin, B. M. (1984). The effects of nonverbal communications in television advertising. Journal of Advertising Research, 24, 11-18.

Haugh, O. M. (1952). The relative effectiveness of reading and listening to radio drama as ways of imparting information and shifting attitudes. Journal of Educational Research, 45, 89-498.

Havlena, W. J.; \& Holbrook, M. B. (1986). The varieties of consumption experience: Comparing two typologies of emotion and consumer behavior. Journal of Consumer Research, 13, 394-404.

Hiffe, A. H. (1960). A study of preferences in feminine beauty. British Journal of Psychology, 51, 267-273.

Hirschman, E. C., \& Holbook, M. B. (1982). Hedonic consumption: Emerging methods and propositions. Journal of Marketing, 46, 92-101.

Horai, J., Naccari, N. \& Fatoullah, E. (1974). The effects of expertise and physical attractiveness upon opinion agreement and liking. Sociometry, 37, 601-606.

Hovland, C. I. Janis, I. L. \& Kelley, H. H. (1953). Communication and Persuasion. New Haven, ct: Yale 
Hunt, J. M., Domzal, T. J., \& Kernan, J. B. (1982). Causal attribution and persuasion: The case of disconformed expectancies. In A. Mitchell (Ed.). Advances in Consumer Research. 2. (pp. 287-292). Pittsburgh: Association for Consumer Research.

Joreskog, K. G., (1971). Simultaneous factor analysis in several populations. Psychometrika, 36, 409-426.

Joreskog, K. G., \& Sorbom, D. (1989). LISREL 7: A guide to the program and applications. (2nd. Ed.). Chicago: SPSS Inc.

Jacoby, J., Hoyer, W. D., \& Zimmer, M. R. (1983). To read, view, or listen? A cross-media comparison of comprehension. Current Issues and Research in Advertising, 1, 201-217.

Joseph, W. B. (1982). The credibility of physically attractive communicators: A review. Journal of Advertising, 11, 15-24.

Joseph, W. B. (1977). Effect of communicator physical attractiveness and expertise on opinion change and information processing. Unpublished doctoral dissertation, Ohio State University, Columbus.

Kahle, L. R., \& Homer, P. M. (1985). Physical attractiveness of the celebrity endorser: A social adaptation perspective. Journal of Consumer Research, 11, 954-961.

Kahle, L. R. (1984). Attitudes and social adaptation: A person situation interaction approach. Oxford: Permagon.

Kahle, L. R., \& Timmer, S. G. (1983). A theory and a method for studying values. In L. R. Kahle (Ed.). Social values and social change: An adaptation to life in America. New York: Praeger.

Kalmar, I., Yong, $Z_{.}$\& Hong, X (1987). Language attitudes in Guangzhou, China. Language and Society, 16, 499-508.

Kamins, M. A. (1990) An investigation into the 'match up' hypothesis in celebrity advertising: When beauty may be only skin deep. Journal of Advertising, 19, 4-13.

Kassarjian, H. H. (1973). Field theory in consumer behavior. In S. Ward, \& T. S. Robertson (Eds.). Consumer behavior: Theoretical sources. Engelwood cliffs, New Jersey:

Kelman, H. C. (1961). Processes of opinion change. Public
opinion Quarterly, $25,57-78$. 
Kenny, D., \& Judd, C. M. (1984). Estimating the monlinear and interactive effects of latent variables. Psychological Bulletin, 96, 2001-210.

Kopera, A. A., Maier, R. A., \& Johnson, J. E. (1971). Perception of physical attractiveness: The influence of group interaction and group coaction on ratings of the attractiveness of photographs of women. Proceedings of the 79 th Annual Convention of the American Psychological Association. 6. 317-318.

Kotler, P., \& Armstrong, G. (1989). Principles of marketing. (4th Ed.). Engelwood Cliffs, New Jersey: Prentice-Hall.

Krugman, H. E. (1971). Brain wave measure for media involvement. Journal of Advertising Research, 11, 3-10.

Labov, W. (1966). The social stratification of English in New York City. Washington, DC: Center for Applied Linguistics.

Labov, W. (1972a). The study of language in its social context. In J. A. Fishman (Ed.). Advances in the sociology of language. (pp. 152-216). Hartford, CT: Newbury House.

Labov, W. (1972b). The reflection of social processes in inguistic structure. In J.A. Fishman (Ed.). Readings in the sociology of language. (pp. 240-251). The Hague: Mouton.

Labov, W. (1972c). Sociolinguistic patterns. Philadelphia: University of Pennsylvania Press.

Labov, W. (1973). The linguistic consequences of being a lame. Language in Society, $2,81-115$.

Lambert, W. E. (1967). A social psychology of bilingualism. Journal of Social Issues, 23, 91-109.

Lambert, W. E. (1980). The social psychology of language: A perspective for the $1980^{\prime} \mathrm{s}$. In H. Giles, W. P. Robinson, \& P. M. Smith (Eds.). Language: Social psychological perspectives. (pp. 415-424). Oxford: Pergamon Press.

Landy, D. \& Sigall, H. (1974). Beauty is talent: Task evaluation as a function of the performer's physical psychology, 29, 299-304. Journal of Personality and Social

Larkin, J. H. McDermott, J., Simon, P. D. \& Simon, H. A. (1980). Expert and novice performance in solving physics 
Laskey, H. A. (1988). Television commercial effectiveness as a function of main message and commercial structure. Unpublished doctoral dissertation, University of Georgia, Athens, 1988.

Laskey, H. A., \& Seaton, B. (1990). operationizing a definition for bilingualism: Categorizing bilinguals using language background and self-assessed proficiency. Unpublished manuscript, Florida International University, Marketing and Ervironment Department, Miami.

Lavidge, R. J., \& Steiner, G. A. (1961). A model for predictive measurements of advertising effectiveness. Journal of Marketing, 25, 59-62.

Liu, S. S. (1986). Picture-image memory of TV advertising in low-involvement situations: A psychophysiological analysis. Current Issues In Research and Advertising, 27-57.

Mardia, K. V. (1970). Measures of multivariate skewness and kurtosis with applications. Biometrika, 57, 519-530.

Markel, N. N., Reiser, R. N., \& Reese, H. W. (1967). Judging personality from dialect. Journal of Verbal Learning and Verbal Behavior, $6,33-35$.

McGinnies, E. A. (1965). A cross-cultural comparison of printed communications versus spoken communications in Persuasion. Journal of Psychology, 60, 1-8.

MCGinnies, E. A. \& Ward, C. D. (1980). Better liked than right: Trustworthiness and expertise as factors in credibility. Personality and Social Psychology Bulletin, 6, $467-472$.

McGraw, B., \& Joreskog, K. G. (1971). Factorial invariance of ability measures in groups differing in intelligence and socioeconomic status. British Journal of Mathematics and Statistics Psychology, 24, 154-168.

McGuire, W. J. (1968). Personality and susceptibility to social influence. In E. F. Borgatta \& W. W. Lambert (Eds.). Handbook of personality theory and research. Chicago: Rand McNally.

McGuire, W. J. (1972): Attitude change: The informationprocessing paradigm. In C. G. McClintock (Ed.). Experimental Social Psychology. New York: Holt, Rinehart and winston. 
Mehrabian, A. (1972). Nonverbal Communication. Chicago: Aldine.

Miller, G. P. \& Basehart, J. (1969). Source trustworthiness, opinionated statements, and response to persuasive communication. Speech Monographs, 36, 1-7.

Miller, A. G. (1970). Role of physical attractiveness in impression formations. Psychonomic Science, 19, 41-243.

Mills, J. S. \& Harvey, J. (1972). Opinion change as a function of when information about the communicator is receptive and whether he is attractive or expert. Journal of Personality and Social Psychology, 21, 52-55.

Nunnally, J. C. (1967) Psychometric Theory. New York: McGraw Hill.

Nunnally, J. C. (1978). Psychometric Theory. New York: MCGraw Hill.

Ohanian, R. (1990). Construction and validation of a scale to measure celebrity endorsers' perceived expertise, trustworthiness, and attractiveness. Journal of Advertising, 19, 39-52.

Ohanian, R. (1991). 'The impact of celebrity spokespersons' perceived image on consumers intention to purchase. Journal of Advertising Research, 31, 46-56.

Osgood, C. E. \& Tannenbaum, P. H. (1955). The principle of congruity in the prediction of attitude change. Psychological Review, 62, 42-55.

Pallak, S. R. (1983). Salience of a communicator's physical attractiveness and persuasion: A heuristic versus systematic processing interpretation. Social cognition, 2. 156-168.

Patzer, G. L. (1983). Source credibility as a function of communicator physical attractiveness. Business Research, 11, 299-241. Journal of

Pavelchak, M. A. (1989). Piecemeal and category-based evaluation: An idiographic analysis. Journal of Personal and Social Psychology, 56, 354-363.

Petty, R. E. \& Cacioppo, J. T. (1986a). The elaboration likelihood model of persuasion. In L. Berkowitz (Ed.). Advances in Experimental Social Psychology. 19. (pp. 123-205). New York: Academic Press. 
Petty, R. E. \& Cacioppo, J. T. (1986b). Communication and persuasion: Central and peripheral routes to attitude change. New York: Springer-Verlag.

Pokrywcznski, J. V. (1986). Advertising effects and viewer involvement with television sports. Unpublished doctoral dissertation, University of Georgia, Athens.

Powesland, P. F. \& Giles, H. (1975). Persuasiveness and accent-message incompatibility. Human Relations, 28, $85-93$.

Rossiter, J. R. \& Percy, L. (1980). Attitude change through visual imagery in advertising. Journal of Advertising. 2. $10-16$.

Ryan, E. B., Carranza, M. A., \& Moffie, R. W. (1977). Reactions toward varying degrees of accentedness in the speech of Spanish-English bilinguals. Language and Speech, 20, 267-273.

Ryan, E. B., \& Carranza, M. A. (1975). Evaluative reactions of adolescents toward speakers of standard English and Mexican-Americar accented English. Journal of Personality and Social Psychology, 31, 855-863.

Ryan, E. B., \& Giles, H. (1982). Attitudes towards language variation: Social and applied contexts. London: Edward Arnold.

Searleman, A. (1977). A review of right hemisphere linguistic capabilities. Psychological Bulletin, 84, 503-528.

Seckbach, F. (1974): Attitudes and opinions of Israeli teachers and students about aspects of modern Hebrew. International Journal of Sociology and Language, 1 . 105-124.

Seggie, I., \& Fulmizi, C., \& stewart, J. (1982). Evaluations of personality traits and employment suitability based on various Australian accents. Australian Journal of Psychology, 34, 345-357.

Severin, W. J., \& Tankard, J. W. Jr. (1979). communication theories: Origins, methods, uses. New York: Hastings

Sherif, M. (1966). In common predicament: Social psychology of intergroup conflict and cooperation. Boston: Houghton

Shimp, T. A. (1990). Promotion management and marketing communications. (2nd. Ed.). Chicago: The Dryden Press. 
Shuy, R. W. (1968). A study of social dialects in Detroit. (Final Report, Project No. 6-1347). Washington, DC.: U.S. Department of Health, Education, and Welfare, office of Education; Bureau of Research.

Sigall, H. \& Aronson, E. (1969). Liking for an evaluator as a function of her physical attractiveness and nature of the evaluations. Journal of Experimental Social Psychology, 5, 93-100.

Smith, C. S., \& Brannick, M. T. (1990). A role and expectancy model of participative decision-making: A replication and theoretical extension. Journal of organizational Behavior, 11, 91-104.

Snyder, M. \& Rothbart, M. (1971). communication attractiveness and opinion change. Canadian Journal of the Behavioural sciences, 377-387.

Sorbom, D. (1974). A general method for studying differences in factor means and factor structure between groups. British Journal of Mathematics and statistics Psychology, 27, 229-239.

Subhash, S., Durand, R. M. \& Gur-Arie, O. (1981). Identification and analysis of moderator variables. Journal of Marketing Research, 17, 291-300.

Sujan, M. (1985). Consumer knowledge: Effects on evaluation strategies mediating consumer judgements. Journal of Consumer Research, 12, 31-46.

Swartz, T. A. (1984). Relationship between source expertise and source attractiveness in an advertising content. Journal of Advertising, 13, 49-55.

Tajfel, H. (1972). Some developments in European social psychology. European Journal of Social Psychology, 2,
307-322.

Tajfel, H. (1974). Social identity and intergroup behavior. Social Information, $13,65-93$.

Tajfel, H. (1978). Differentiation between social groups. London: Academic Press. Tajfel, H. (1981). Human groups and social categories. Tajfel, H. (1982). Social psychology of intergroup relations.
In H. Tajfel (Ed.).
(pp. 1-39). Palo alto, $\frac{\text { Annual Review of Psychology. }}{\mathrm{Ca}}$. (pp. 1-39). Palo alto, Ca: Annual Reviews. 
Tajfel, H., \& Turner, J. C. (1979). An integrative theory of intergroup conflict. In W. G. Austin \& S. Worchel (Eds.). The social psychology of intergroup relations. Monterey, Ca: Brooks/Cole.

Tannenbaum, P. H. \& Kerrick, J. S. (1954). Effects of newscast item leads upon listener interpretation. Journalism Quarterly, 31, 33-37.

Taylor, D. M. \& Guimond, S. (1978). The belief theory of prejudice in an intergroup context. Journal of Social Psychology, 105, 11-25.

Tsalikis, J., Deshields, O. W. \& LaTour, M. S. (1991). The role of accent on the credibility of the salesman. Journal of Personal Selling and Sales Management, 11, 31-41.

Tucker, G. R., \& Lambert, W. E. (1969). White and Negro listeners' reactions to various American-English dialects. Journal of Social Forces, 47, 463-468.

Turner, J. C. (1975). Social comparison and social identity: Some prospects for intergroup behavior. European Journal of Social Psychology, $5,5-34$.

Turner, J. C. (1978). Social categorization and social discrimination in the minimal group paradigm. In $H$. Tajfel (Ed.). Differentiation between social groups: studies in the social psychology of intergroup relations. London: Academic Press.

Umberson, D. \& Hughes, M. (1987). The impact of physical attractiveness on achievement and psychological wellbeing. Social Psychology Quarterly, 50, 227-236.

Wackman, D. B. (1973). Theories of interpersonal perception. In S. Ward \& T. S. Robertson (Eds.). Consumer behavior: Theoretical sources. Engelwood cliffs, N.J.: Prentice Hall.

Webster, M. Jr., \& Driskell, J. E. Jr. (1983). Beauty as status. American Sociological Review, 89, 140-165.

Westover, F. L. (1958). A comparison of listening and reading as a means of testing. Journal of Educational Research, Wickelgren, W. A. (1981). Human learning and memory. Annual
Review of Psychology, $32,21-52$. 
Wider, D. A. (1978). Perceiving persons as a group: Effects on attribution of causality and beliefs. Social Psychology, 1, 13-23.

williams, F., Hewett, N., Miller, L., Naremore, $R_{\text {, \& \& }}$ Whitehead, J. I. (1972). Explorations of the linguistic attitudes of teachers. Rowley, Ma: Newbury House.

Wilson, C. E. (1974). The effect of medium on loss of information. Journalism Quarterly, 51, 111-115.

Woolard, K. A. (1984). A formal measure of language attitudes in Barcelona: A note from work in progress. International Journal of Society and Lanquage, 47, 63-71.

Worchel, S., Andreoli, V., \& Eason, J. (1975). Is the medium the message? A study of the effects of media, communicatcr, and message characteristic on attitude change. Journal of Applied Social Psychology, $\underline{5}$, 157-172.

Zaichkowsky, J. L. 1985. Measuring the involvement construct. Journal of Consumer Research, 12, 350 .

Zavalloni, M. (1972). Cognitive processes and social identity through focused introspection. European Journal of Social Psychology, 2, 235-260.

Zalvalloni, M. (1973). Social identity: Perspectives and prospects. Social Scientific Information, 12, 65-92.

Zalvalloni, M. (1975). Social identity and the recording of reality: Its relevance for cross-cultural psychology. International Journal of Psychology, 10, 197-217. 